\title{
ASSESSMENT OF WATER RESOURCES IN LEAD-ZINC MINED AREAS IN CHEROKEE COUNTY, KANSAS, AND ADJACENT AREAS
}

U.S. GEOLOGICAL SURVEY

Open-File Report 84-439

Prepared in cooperation with the

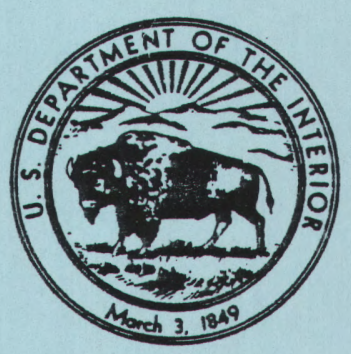

KANSAS DEPARTMENT OF HEALTH AND ENVIRONMENT 

ASSESSMENT OF WATER RESOURCES IN LEAD-ZINC

MINED AREAS IN CHEROKEE COUNTY, KANSAS,

AND ADJACENT AREAS

By Timothy B. Spruill

U.S. GEOLOGICAL SURVEY

Open-File Report 84-439

Prepared in cooperation with the

KANSAS DEPARTMENT OF HEALTH AND ENVIRONMENT 
UNITED STATES DEPARTMENT OF THE INTERIOR

\author{
WILLIAM P. CLARK, Secretary \\ GEOLOGICAL SURVEY \\ Dallas L. Peck, Director
}

For additional information write to:

District Chief

U.S. Geological Survey, WRD

1950 Constant Avenue - Campus West

University of Kansas

Lawrence, Kansas 66044-3897

[Telephone: (913) 864-4321]
Copies of this report can be purchased from:

Open-File Services Section Western Distribution Branch U.S. Geological Survey Box 25425, Federal Center Denver, Colorado 80225

[Telephone: (303) 234-5888] 
Abstract- . . . . . . . . . . . . . 1

Introduction- ........... . . . . . . . - 2

Purpose and scope- . . . . . . . . . . . . 3

Historical background- _ . . . . . . . . . . 3

Review of contamination problems - . . . . . . . . 7

The study area- ..................... 9

Methods _ . . . . . . . . . . . . . . . . 15

Sample collection and laboratory procedures- . . . . - - 15

Analysis of data . . . . . . . . . . . . . 18

Hydrogeology - . . . . . . . . . . . . . - 18

Ground water . . . . . . . . . . . . . 18

Shall ow aquifer - ... . . . . . . . - 18

Deep aquifer- ................... 23

Effects of abandoned mines on ground-water hydrology- - - 24

Surface water- . . . . . . . . . . . . - 31

Regional characteristics. - . . . . . . . . 31

Effects of abandoned mines on streamflow- . - . - . - 33

Quality of water- . . . . . . . . . . . . . . - 34

Ground water . . . . . . . . . . . . 34

Shallow aquifer - . . . . . . . . . . . 34

Deep aquifer . . . . . . . . . . . . . 39

Effects of abandoned mines on water quality - . . . . 42

Surface water- . . . . . . . . . . . . 51

Regional characteristics. . . . . . . . . . 51

Effects of abandoned mines on water quality - . - . - 55

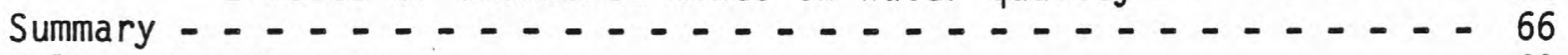

Selected references - . . . . . . . . . . . . - 68

Supplemental information - - - . - - - - - - . - - 72

Computations for downward leakage _........... 81

\section{ILLUSTRATIONS}

Figure

1. Map showing principal part of Tri-State lead-zinc district, mined areas, and location of study area - . . . . . . 4

2. Graph showing production of aggregate lead and zinc concentrates in the Tri-State lead-zinc district, 1850-1970 - - . 6

3. Map showing location of ground-water sampling sites . . . - 10

4. Map showing location of surface-water sampling sites- . - - 11

5. Map showing generalized geologic features of study area - - - 13

6. Geologic section from near Treece, Kansas, to Joplin, Missouri- 14 


\section{ILLUSTRATIONS--Continued}

Figure

Page

7. Map showing location of major brecciated zones in eastern area

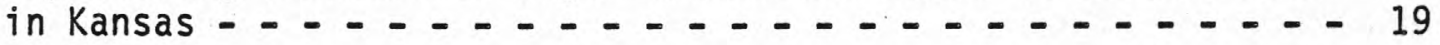

8. Schematic diagram showing generalized hydrologic characteristics of shallow aquifer in eastern part of study area- . . - . - 20

9. Map showing potentiometric surface of shallow aquifer $-\ldots$

10. Map showing potentiometric surface of deep aquifer- - - - - 25

11. Map showing approximate differences in hydraulic head between shallow and deep aquifers $\ldots \ldots \ldots$

12. Schematic drawing illustrating effects of abandoned leadzinc mines on ground-water hydraulics in western area - - - - 27

13. Gammma log from well at Galena, Kansas- _ . . . . . . . 30

14. Flow-duration curves of streams draining Pennsylvanian-age shales (Lightning Creek) and Mississippian-age limestones

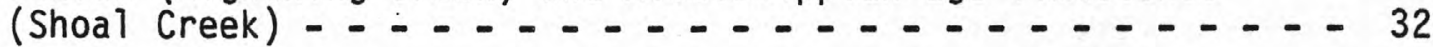

15. Map showing chemical-quality characteristics of water from selected wells and mines in shallow aquifer _ . . . . . . 37

16. Map showing chemical-quality characteristics of water from selected wells in deep aquifer- _. . . . . . . . . . . 40

17. Graph showing changes through time in selected chemical constituents and physical properties in samples from lower level of Consolidated No. 2 mine, Oklahoma - . . . . . . . . . . 49

18. Graphs showing sulfate concentrations in water from selected public-supply wells _ _ . . . . . . . . . . . . 52

19. Map showing chemical-quality characteristics of selected streams in study area _... . . . . . . . . . . . 54

20. Graph showing downstream changes in chemical types of water and concentrations of selected chemical constituents in water from four sampling sites on Short Creek, August 1981- - - - 58

21. Graph showing relationship of total and dissolved concentrations of selected chemical constituents to discharge in water from Short Creek at Galena, 1981-82 _. . . . . . . . . - 60

22. Graph showing downstream changes in concentrations of selected chemical constituents in water from six sampling sites on Spring River, August $1981 \ldots \ldots 2$ 
Figure

23. Graph showing downstream changes in concentrations of selected chemical constituents at two sampling sites on Tar Creek, June and August 1981. . . . . . . . . . . . 64

\section{TABLES}

Table

1. Comparison of crude ore extracted in Tri-State lead-zinc district, 1850-1970, and estimated volume of water in flooded mines _.................... 5

2. Comparison of crude ore extracted from three mining districts in Kansas, 1876-1970, and estimated volume of water in flooded mines. ..................... 7

3. Potential water-quality problems associated with abandoned lead and zinc mines . . . . . . . . . . . ... 8

4. Generalized section of geologic formations and their estimated hydraulic properties. . . . . . . . . . 16

5. Hypothetical estimate of the volume of water that could discharge to the deep aquifer through an open, 7-inch well casing for a 50-foot and a 450-foot difference in hydraulic heads between the shallow and deep aquifers ........ 31

6. Summary of water-quality data for wells in the shallow aquifer .................... 35

7. Selected chemical constituents and physical properties of water for wells in the shallow aquifer with percentages of observed values exceeding maximum contaminant concentrations established by the U.S. Environmental Protection Agency- - - 36

8. Summary of water-quality data for mines in the shallow aquifer .................... 38

9. Summary of water-quality data for wells in the deep aquifer - 41

10. Selected chemical constituents and physical properties of water for wells in the deep aquifer with percentages of observed values exceeding maximum contaminant concentrations established by the U.S. Environmental Protection Agency - - - 42

11. Statistical summary of selected chemical constituents in water collected from mines and concentration mills near Galena, Kansas, during March and April 1905. . . . . 44 
12. Comparison of selected chemical constituents and physical properties of water for mines in eastern and western parts of the Picher Field, Cherokee County, Kansas- - . - . . 46

13. Comparison of selected chemical constituents and physical properties of water for upper and lower levels of mines in the Picher Field, Kansas and Oklahoma _... . . . . . 48

14. Summary of low-flow water-quality data for selected streams in study area .................. 56

15. Minimum, median, and maximum concentrations of selected chemical constituents observed in samples obtained at low and medium flows from Tar Creek, 1976-82 - . . . . . . 65

16. Location and information for mines in the shallow aquifer - - 75

17. Location and information for wells in the shallow aquifer - - .77

18. Location and information for wells in the deep aquifer- - - 79

19. List of surface-water sampling sites- . . . . . . . - 80

20. Water-quality data for wells in shallow aquifer . . . . . 81

21. Water-quality data for mines in shallow aquifer ...... 83

22. Water-quality data for wells in deep aquifer- . . . . . 94

23. Water-quality data for surface-water sites- - . - . - . 96

24. Historical chemical water-quality data for wells in shallow and deep aquifers in Kansas _............. 100

25. Chemical constituent or physical property analysed, reporting units, and detection limits - . - . - . - 101

26. Streamflow and mass-balance calculations for gains and losses in loads of dissolved manganese, cadmium, and zinc for seepage-salinity survey conducted on Short Creek, August 12, $1981 \ldots \ldots 102$ 
To aid those readers who are interested in the International System of Units (SI), the factors for converting from the inch-pound units used in this report to metric units are given below:

Multiply

inch-pound unit

inch

foot

mile

acre

square mile

gallon

cubic foot

acre-foot

pound per day ( $1 \mathrm{~b} / \mathrm{d})$

ton, short

foot per second $(\mathrm{ft} / \mathrm{s})$

foot squared per day $\left(\mathrm{ft}^{2} / \mathrm{d}\right)$

cubic foot per second $\left(\mathrm{ft}^{3} / \mathrm{s}\right)$

gallon per minute (gal/min)

acre-foot per year

(acre-ft/yr)

gallon per day per square foot $\left[(\mathrm{gal} / \mathrm{d}) / \mathrm{ft}^{2}\right]$

gallon per day per square mile $\left[(\mathrm{gal} / \mathrm{d}) / \mathrm{mi}^{2}\right]$

cubic foot per second per square mile $\left[\left(\mathrm{ft}^{3} / \mathrm{s}\right) / \mathrm{mi}^{2}\right]$

degree Fahrenheit $\left({ }^{\circ} \mathrm{F}\right)$

micromho per centimeter at $25^{\circ}$

Celsius ( $\mu$ mhos $/ \mathrm{cm}$ at $25^{\circ} \mathrm{C}$ )
By

$1 / 25.4$

0.3048

1.609

0.4047

2.590

3.785

0.02832

1,233

453.6

0.9072

0.3048

0.09290

28.32

0.06309

1,233

40.74

1.4613

10.93

2)

1.000
To obtain metric (SI) unit

millimeter

meter

kilometer

square hectometer

square kilometer

liter

cubic meter

cubic meter

gram per day

megagram

meter per second

meter squared per day

liter per second

liter per second

cubic meter per year

liter per day per square meter

liter per day per square kilometer

cubic meter per second per square meter

degree Celsius $\left({ }^{\circ} \mathrm{C}\right)$

microsiemens per centimeter at $25^{\circ} \mathrm{Cel}$ sius

1 Exact conversion factor.

$2{ }^{\circ} \mathrm{C}=\left({ }^{\circ} \mathrm{F}-32\right) / 1.8$. 
viii 
ASSESSMENT OF WATER RESOURCES IN LEAD-ZINC

MINED AREAS IN CHERKOEE COUNTY, KANSAS,

AND ADJACENT AREAS

By Timothy B. Spruil1

\section{ABSTRACT}

A study was conducted to evaluate water-resources problems related to abandoned lead and zinc mines in Cherokee County, Kansas, and adjacent areas in Missouri and Oklahoma. Past mining activities have caused changes in the hydrogeology of the area. Lead and zinc mining has caused discontinuities and perforations in the confining shale west of the Pennsylvanian-Mississippian geologic contact (referred to as the western area), which have created artificial ground-water recharge and discharge areas. Recharge to the shallow aquifer (rocks of Mississippian age) through collapses, shafts, and drill holes in the shale has caused the formation of a groundwater "mound" in the vicinity of the Picher Field in Kansas and Oklahoma. Discharge of mine-contaminated ground water to Tar Creek occurs in Oklahoma from drill holes and shafts where the potentiometric surface of the shallow aquifer is above the land surface. Mining of ore in the shallow aquifer has resulted in extensive fracturing and removal of material, which has created highly transmissive zones and voids and increased ground-water storage properties of the aquifer. In the area east of the Pennsylvanian-Mississippian geologic contact (referred to as the eastern area), fractured rock and tailings on the land surface increased the amount of water available for infiltration to the shallow aquifer; in the western area, tailings on the impermeable shale created artificial, perched aquifer systems that slowly drain to surface streams.

Pumping of the deep aquifer (rocks of Cambrian and Ordovician age) by towns and industries, which developed as a result of the mining industry, has resulted in a potential for downward movement of water from the shallow aquifer. The potential is greatest in Ottawa County, OKlahoma. Because of the large volume of water that may be transported from the shallow to the deep aquifer, open drill holes or casings present the greatest contamination hazard to water supplies in the deep aquifer.

Mining allowed oxidation of ore deposits which, on saturation with water, resulted in poor-quality water that generally contains large concentrations of sulfate and trace metals. Water from mines in the eastern area contained dissolved-solids concentrations of less than $500 \mathrm{mg} / \mathrm{L}$ (milligrams per liter), a median pH of 3.9 , sulfate concentrations that ranged between 98 and $290 \mathrm{mg} / \mathrm{L}$, and median concentrations for zinc of $37,600 \mu \mathrm{g} / \mathrm{L}$ (micrograms per liter), for lead of $240 \mu \mathrm{g} / \mathrm{L}$, for cadmium of $180 \mathrm{\mu g} / \mathrm{L}$, for iron of $70 \mathrm{\mu g} / \mathrm{L}$, for manganese of $240 \mu \mathrm{g} / \mathrm{L}$, and for silica of $15 \mathrm{mg} / \mathrm{L}$. Water from mines in the western area contained dissolved-solids concentrations of generally more than $500 \mathrm{mg} / \mathrm{L}$, a median $\mathrm{pH}$ of 6.8 , sulfate concentrations that ranged between 170 and $2,150 \mathrm{mg} / \mathrm{L}$, and median concentrations for zinc of $3,200 \mu \mathrm{g} / \mathrm{L}$, for lead of $0 \mu \mathrm{g} / \mathrm{L}$ (minimum detection limit 
is $10 \mu \mathrm{g} / \mathrm{L})$, for cadmium of $6 \mu \mathrm{g} / \mathrm{L}$, for iron of $840 \mu \mathrm{g} / \mathrm{L}$, for manganese of $440 \mathrm{\mu g} / \mathrm{L}$, and for silica of $11 \mathrm{mg} / \mathrm{L}$.

No conclusive evidence of lateral migration of water from the mines into domestic well-water supplies in the shallow aquifer was found in the study area in Kansas. Analyses of water from public-supply wells tapping the deep aquifer did not indicate contamination with trace metals, although chemical analyses from four of six wells exhibited increasing trends through time in sulfate concentrations. These increases probably reflect localized leakage of water from the shallow aquifer along corroded or leaky well casings.

Effects of abandoned lead and zinc mines on tributaries of the Spring River in the eastern area are most severe in Short Creek. Compared with water samples from three other major streams in the eastern area, a sample collected from Short Creek, 2 miles west of Galena, Kansas, during August 1981 , contained the largest concentrations of dissolved sulfate $(240 \mathrm{mg} / \mathrm{L})$, zinc $(25,000 \mu \mathrm{g} / \mathrm{L})$, cadmium $(170 \mu \mathrm{g} / \mathrm{L})$, manganese $(1,700 \mu \mathrm{g} / \mathrm{L})$, and the lowest pH (6.0). Concentrations of these constituents are due primarily to inflow of ground water from the breccia, mines, and to seepage from chat piles in the Short Creek basin. The largest concentrations of zinc and manganese in the Spring River during August 1981, were observed in analyses of samples collected below Short Creek. In the western area, drainage from tailings, which act as perched aquifers on the impervious Pennsylvanian shales, appeared to have little effect on water quality in Willow Creek during low-flow conditions but caused larger concentrations of dissolved zinc just after a wet period during June 1981. Drainage from tailings cause large concentrations of sulfate, zinc, and cadmium in Tar Creek in Kansas. Compared with four other major streams in the western area in Kansas, Tar Creek contained the largest low-flow concentrations of sulfate $(910 \mathrm{mg} / \mathrm{L})$, zinc $(5,800 \mu \mathrm{g} / \mathrm{L})$, and cadmium $\left(40^{\circ} \mu \mathrm{g} / \mathrm{L}\right)$.

\section{INTRODUCTION}

Lead and zinc ores were mined in Cherokee County, Kansas, and adjacent areas in Missouri and OKlahoma for more than 100 years. Various problems with both ground- and surface-water contamination have been attributed to abandoned lead and zinc mines in Missouri and Oklahoma studies (Bailey, 1911; Barks, 1977; Haworth, 1904; Hittman Associates, 1981; Kansas Department of Health and Environment, 1980; Oklahoma Water Resources Board, 1981; Playton and others, 1978; Reed and others, 1955).

To assess the effects of abandoned lead and zinc mines on water resources in the Kansas part of the Tri-State District, the U.S. Geological Survey, as part of a cooperative program with the Kansas Department of Health and Environment, conducted a study to evaluate actual or potential water-resources problems related to abandoned lead and zinc mines in Cherokee County, Kansas, and adjacent areas in Missouri and 0klahoma. 


\section{Purpose and Scope}

The purpose of this report is to:

(1) Define water-quality characteristics of ground and surface waters of the lead-zinc mined areas of Cherokee County and adjacent areas,

(2) define the type and extent of chemical pollution, and

(3) describe the hydrology and geochemistry of the area.

Water-quality samples were collected and analyzed from wells, mines, and streams in the study area, and water levels were measured at wells and mines to describe water-quality and other hydrologic characteristics of the area. Chemical quality and water-level data obtained from previous studies were used also to allow as complete coverage of the area as possible, to fill in gaps where samples and water levels could not be obtained without drilling of new wells, and to provide a regional backdrop for the discussion of findings of the study in the Kansas part of the Tri-State District. Several geophysical and lithologic logs and well-construction records were utilized to clarify interpretations regarding hydraulic properties of rocks in the area. As much information from the literature as possible was incorporated to provide insight into interpretation of data obtained from this study.

An attempt was made, using hydrogeologic data compiled primarily from studies in Missouri, to estimate hydraulic properties of rocks in the study area and to estimate quantities of water in storage and in transit within the principal aquifer systems studied. Unpublished geologic data from a study of water resources of Cherokee County, Kansas, conducted by the U.S. Geological Survey in the early 1960's, were used to aid in evaluating lithologic and hydraulic properties of geologic units in Kansas. Interpretations of drill cuttings by various geologists of the Kansas Geological Survey, the U.S. Geological Survey, and the Missouri Geological Survey were used in lithologic descriptions shown in this report. Many of these descriptions are similar to those found in Feder and others (1969).

\section{Historical Background}

Lead and zinc ores in rocks of Mississippian age were mined in southeastern Cherokee County, Kansas, and adjacent areas in Missouri and Oklahoma for approximately 100 years. The location of major lead and zinc mines in the Tri-State District of Missouri, Kansas, and OKlahoma is shown in figure 1. Between 1850 and 1970 , approximately 460 million tons of lead and zinc ores were produced from the entire Tri-state District, with Kansas producing approximately 24 percent of the total (table 1). Production of lead began in Missouri around 1850 and peaked between 1900 and 1910. Production in Missouri ceased by 1957. Lead and zinc were mined in Kansas and Oklahoma beginning around the turn of the century and peaked by 1926. Major production in these states ended by the early 1960's, and the last mine in 


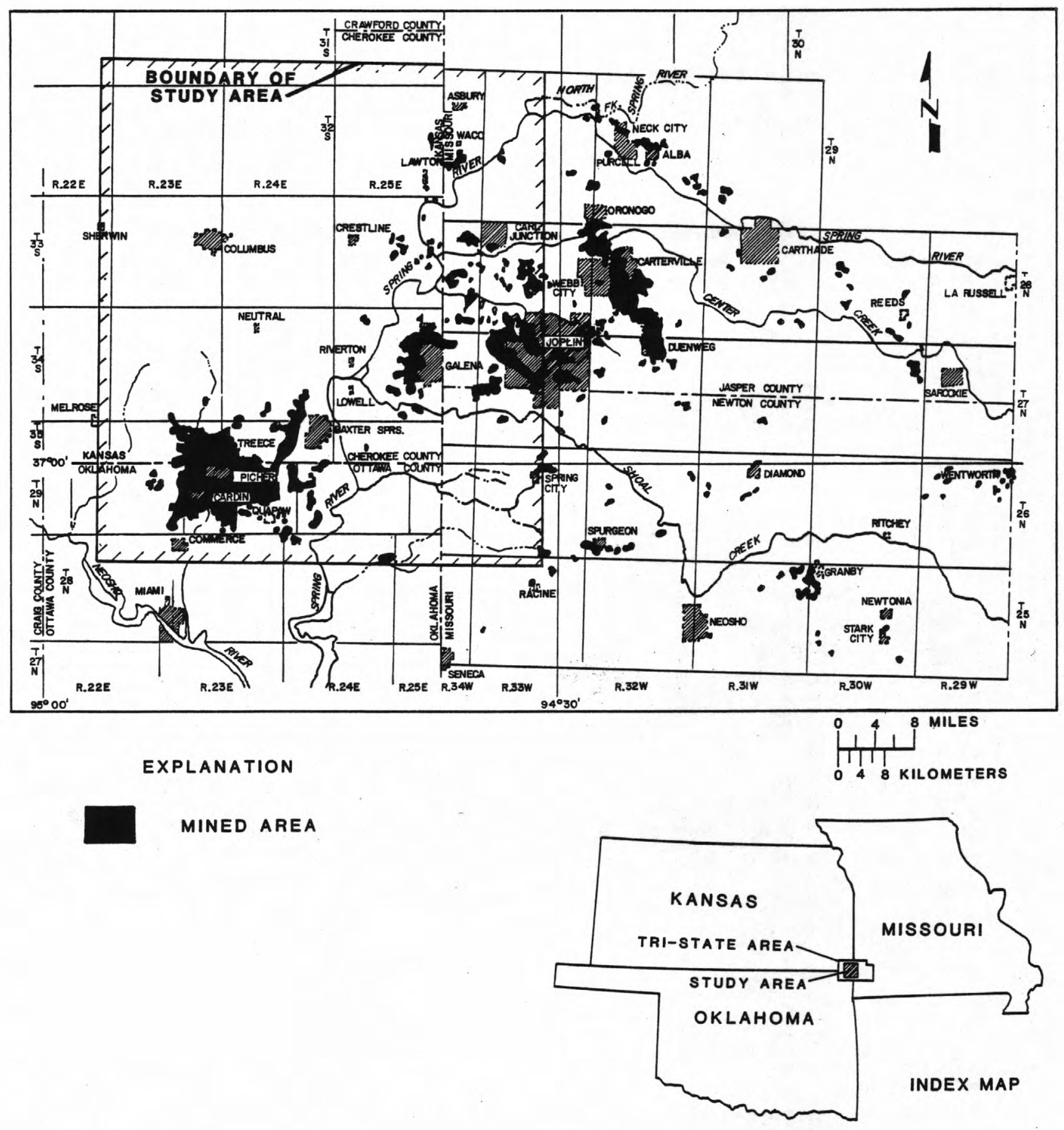

Figure 1.--Principal part of Tri-State lead-zinc district, mined areas, and location of study area (modified from Feder and others, 1969). 
Table 1.--Comparison of crude ore extracted in Tri-State lead-zinc district, 1850-1970, and estimated volume of water in flooded mines

[Data from Martin (1946) and U.S. Bureau of Mines (1946-70)]

\begin{tabular}{|c|c|c|c|c|c|}
\hline State & Period & $\begin{array}{c}\text { Crude ore } 1 \\
\text { (tons) }\end{array}$ & $\begin{array}{l}\text { Volume of } \\
\text { rock } 2 / \\
\text { (cubic feet) }\end{array}$ & $\begin{array}{l}\text { Volume } \\
\text { of mine } \\
\text { water } 3 \text { - } \\
\text { (acre- } \\
\text { feet) }\end{array}$ & $\begin{array}{l}\text { Percentage } \\
\text { of total } \\
\text { crude ore } \\
\text { extracted, } \\
\text { by State }\end{array}$ \\
\hline $\begin{array}{l}\text { Southwest } \\
\text { Missouri }\end{array}$ & $1850-19574$ & $181,373,800$ & $2,267,172,000$ & 52,050 & 39.5 \\
\hline Kansas & $1876-1970$ & $111,142,400$ & $1,389,280,000$ & 31,890 & 24.2 \\
\hline Oklahoma & $1891-1970$ & $167,068,000$ & $2,088,349,000$ & 47,940 & 36.3 \\
\hline Total & & $459,584,200$ & $5,744,801,000$ & 131,880 & 100.0 \\
\hline
\end{tabular}

1 Crude ore figures were not available in the sources consulted for years before 1907 and after 1945. For years when crude-ore production figures were not available, the zinc-concentrate values were divided by 0.059 (ore throughout the district is composed of approximately 5.9 percent zinc concentrate), and the tonnage of crude ore was obtained.

2 The conversion factor of 12.5 cubic feet per ton (Edward Hare, Hickory Creek 0il Company, oral commun., 1982) was used to estimate volume of rock extracted from mines.

3 It was assumed that the mines have completely filled.

4 Mining ended in southwestern Missouri by 1960 .

Kansas closed in 1970. Production of lead and zinc concentrates for each state for 1850-1970 is shown in figure 2.

Mining of lead and zinc occurred in three general areas of Kansas. The Galena Field, which was mined first, is located around Galena, east of the Spring River (fig. 1). Major production from mines in this area produced lead and zinc from about 1876 until 1920. The Badger-Peacock and Crestline-Lawton Area is located between Crestline and Lawton, Kansas, west of the Spring River. The Picher Field, located in Kansas and Oklahoma, was mined from 1891 until 1970, when the last mine closed down west of Baxter Springs, Kansas. Major production from the northern part of the Picher Field, which is located in Kansas between Baxter Springs and Treece, did not begin until 1917 (Martin, 1946, p. 59). Production estimates from these three general areas are shown in table 2. 


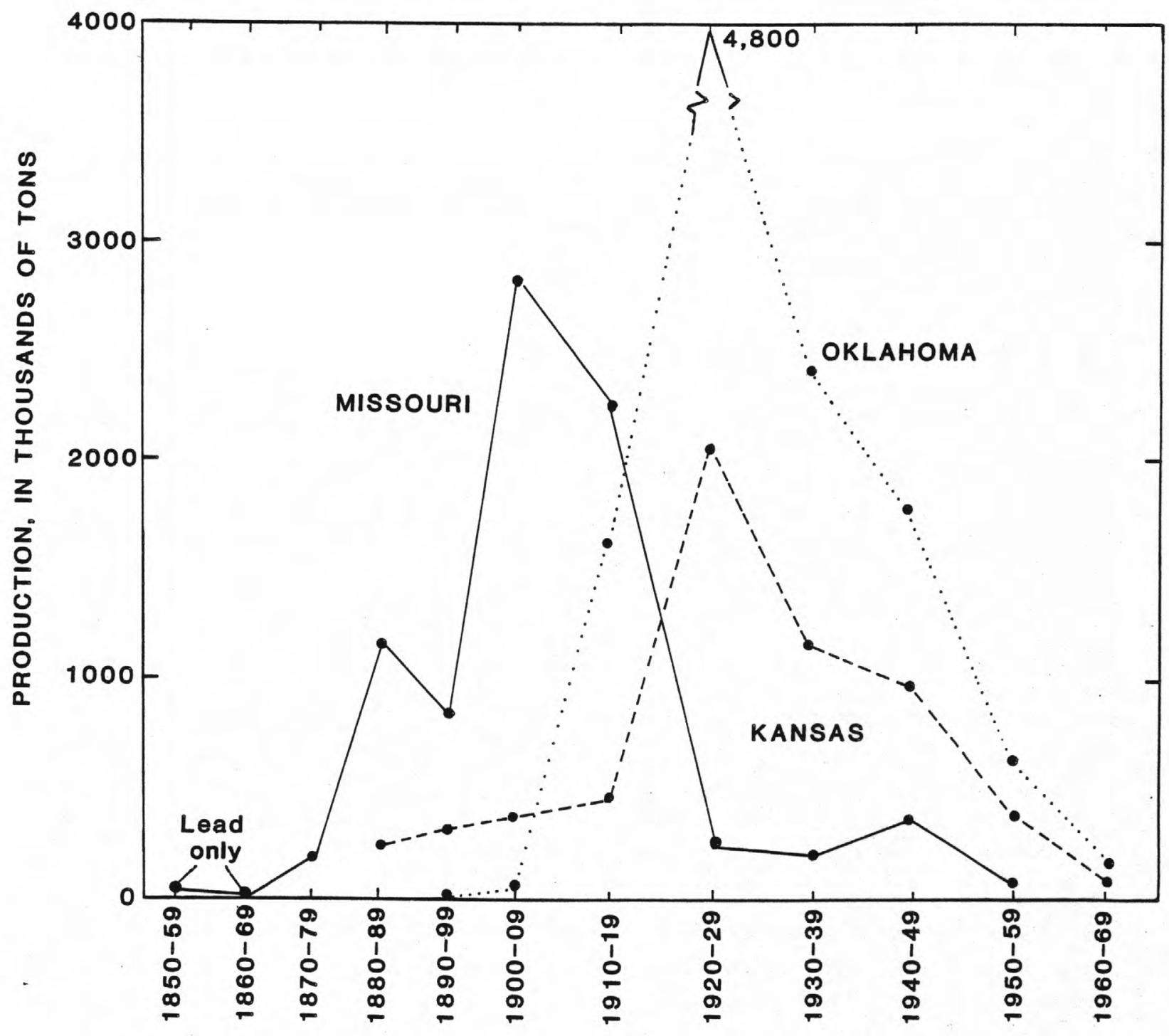

Figure 2.--Production of aggregate lead and zinc concentrates in Tri-State lead-zinc district, 1850-1970. Data from Martin (1946) and U.S. Bureau of Mines (1946-70).

Techniques used to mine the ores consisted of sinking a shaft in the vicinity of an ore body discovered by the drilling of exploration holes. Ground water then was pumped from the shaft and discharged into surface reservoirs or directly to streams so that "drifts" or lateral openings could be developed and the ore removed. The ore was transported to the shaft by means of cars on a track or tramway and removed for processing at the mill, which was usually located near the shaft. Wastes from the milling operations, called "chat" or tailings, were deposited around the mi11. Chat piles could reach 100 to 300 feet in height and cover several acres. 
Table 2.--Comparison of crude ore extracted from three mining districts in Kansas, 1876-1970, and estimated volume of water in flooded mines

[Data from Martin (1946) and U.S. Bureau of Mines (1946-70)]

Area

Period

Crude ore Volume of rock

(tons)

(cubic feet)

Volume of Percentage mine water of total

acre-feet) crude ore extracted, by area

$\begin{array}{lrrrrr}\begin{array}{l}\text { Baxter Springs } \\ \text { Treece }\end{array} & 1917-70 & 85,570,600 & 1,069,633,000 & 24,550 & 77.0 \\ \begin{array}{l}\text { Badger-Peacock } \\ \text { and Crest7ine- }\end{array} & 1904-45 & 7,043,000 & 88,037,000 & 2,020 & 6.3 \\ \begin{array}{l}\text { Lawton } \\ \text { Galena }\end{array} \quad 1876-1945 & \frac{18,528,800}{111,142,400} & \frac{231,610,000}{1,389,280,000} & \frac{5,320}{31,890} & \frac{16.7}{100.0} \\ \quad \text { Total } & & 11,14,400 & & & \\ \end{array}$

Review of Contamination Problems

Between 1850 and 1970, over 5.5 billion cubic feet of rock and crude ore were removed from the Tri-State District. Approximately 132,000 acrefeet of water are contained in abandoned mines in the Tri-State District (table 1). In Kansas, approximately 32,000 acre-feet of mine water resulted, with 77 percent located in the mine field west of Baxter Springs, 16.7 percent in the Galena area, and 6.3 percent in the Badger-CrestlineLawton area (table 2).

As a result of removal of ore-bearing rock, the hydrologic system may be affected in several ways. The major water-quality problems that may result from mining are summarized in table 3.

Surface-water quality problems have been reported within the Tri-State District since the early 20th century. Haworth (1904) noted that water from Shoal Creek was utilized for domestic consumption in the Galena area before mining began. However, as mining activities increased, water from Shoal Creek became "perceptibly contaminated with iron sulphate and zinc sulphate, making it somewhat objectionable." As a result, Empire City (now a part of Galena) "put down a deep well for artesian water and obtained a good supply not so highly mineralized as that coming from Shoal Creek and quite suitable for boilers" (Haworth, 1904, p. 94-95).

Other tributaries of the Spring River, such as Center, Turkey, and Short Creeks, which originate in Missouri, have exhibited evidence of being affected by mine drainage. Turkey and Short Creeks were reported to 
Table 3.-- Potential water-quality problems associated with abandoned lead and zinc mines

I. Surface water

A. Drainage of acid mine water from the drift and chat may have concentrations of trace chemical elements that are biologically detrimental.

B. Streams draining mined areas may contain large concentrations of sediment.

II. Ground water

A. Increased mineralization and lowered $\mathrm{pH}$ of water may be caused by the oxidation and solution of the disturbed rock.

B. Contamination of ground water in the shallow aquifer (Mississippian rocks) may occur by lateral migration of contaminated water in the mines to adjacent unmined parts of the aquifer.

C. Contamination of ground water in the deep aquifer (CambrianOrdovician rocks) may occur by downward migration through vertical fractures or unplugged wells.

contain large concentrations of sulfate, indicative of mine drainage, early in the 20th century (Bailey, 1911). More recently, Barks (1977) reported that the significant effects of abandoned mines in Center and Turkey Creek were (1) large dissolved-zinc concentrations during low flows due to subsurface seepage from the mines and sustained large concentrations of zinc at high flows from runoff from tailings piles, and (2) large zinc and lead concentrations in the bed material from deposition of tailings on the stream bottom.

The Kansas Department of Health and Environment (1980) reported that Short Creek, located near Galena, Kansas, was influenced by runoff and effluent containing large concentrations of zinc and cadmium from a smelter, as well as by a large nutrient concentration from effluent and seepage from a fertilizer plant located in Missouri (Kansas Department of Health and Environment, 1980, p. 28). This report further noted that before 1970, during runoff periods or during mine-dewatering operations, 1 arge concentrations of zinc and iron were introduced into the Spring River from Willow Creek, a tributary entering near Baxter Springs, Kansas (Kansas Department of Health and Environment, 1980, p. 31).

Tar Creek, which flows from Kansas into Oklahoma, has been contaminated recently with discharges of mine water from old drill holes near Commerce, Oklahoma (Hittmann Associates, 1981; Oklahoma Water Resources Board, 1981). These discharges, which began around 1979, are due to the rise of water 
levels within the mines. Discharges occur where open drill holes penetrate shales confining the underlying mined shallow aquifer and where the potentiometric surface of the aquifer is above the land surface. Large concentrations of dissolved lead, zinc, and cadmium and low pH occur in water from these drill holes and degrade stream-water quality below the discharge point.

In Missouri, Barks (1977) reported that although wells developed in the shallow aquifer (composed of rocks of Mississippian age--the geologic system that was mined) could be affected seriously by mine water near mining areas, there was no apparent widespread dispersion of contaminated water throughout the shallow aquifer ( $p$. 33-34). He further reported that although water quality in the deep aquifer, composed of rocks of Cambrian and Ordovician ages, was generally excellent, some deep wells near Webb City and Carthage, Missouri, could be contaminated with mine water ( $p .34)$. Playton and others (1978) concluded that mines in the Picher Field of OKlahoma and Kansas contained water that was not useable for any purpose and that water in the mines could migrate into and contaminate the Roubidoux Formation, shallow aquifers, or surface waters. Reed and others (1955, p. 131) stated that mine water possibly could move from the mined Mississippian rocks downward to the Cambrian-Ordovician rocks, the principal public-supply source in southeastern Kansas, southwestern Missouri, and northeastern Oklahoma. However, MacFarlane and others (1982, p. 32) state that al though hydrostatic-head differences in the Mississippian and Cambrian-Ordovician systems favor downward movement, no evidence of downward leakage was found.

\section{THE STUDY AREA}

The study area occupies 735 square miles in southeastern Kansas, southwestern Missouri, and northeastern Oklahoma, with approximately 410 square miles located in Cherokee County, Kansas (fig. 1). The major data-collection effort for this study was confined primarily to the area in Cherokee County. The location of ground- and surface-water sampling sites is shown in figures 3 and 4 .

Southeastern Cherokee County receives from 40 to 45 inches of rain annually and has a mean monthly temperature during January of between 30 and $40^{\circ} \mathrm{F}$ and during August of between 80 and $90^{\circ} \mathrm{F}$. Peak rainfall amounts occur in the spring and early fall, and minimum rainfall amounts occur during the winter and summer months. Maximum runoff, erosion, and sediment transport in streams generally occur in the spring and fall. A major part of streamflow in the dry summer and winter months is sustained by discharge of ground water from rocks and soils (base flow).

The study area is located within the 0sage section of the Central Lowlands and Ozark Plateau physiographic provinces proposed by Frye and Schoewe (1953). The Osage section of the Central Lowlands Province encompasses the area west of the Pennsylvanian-Mississippian contact (fig. 5) and is typical of the rolling prairie of eastern Kansas. This will be referred to as the western area. The Neosho River, located south and west of the study area, drains the 0sage section of the Central Lowlands and receives drainage 


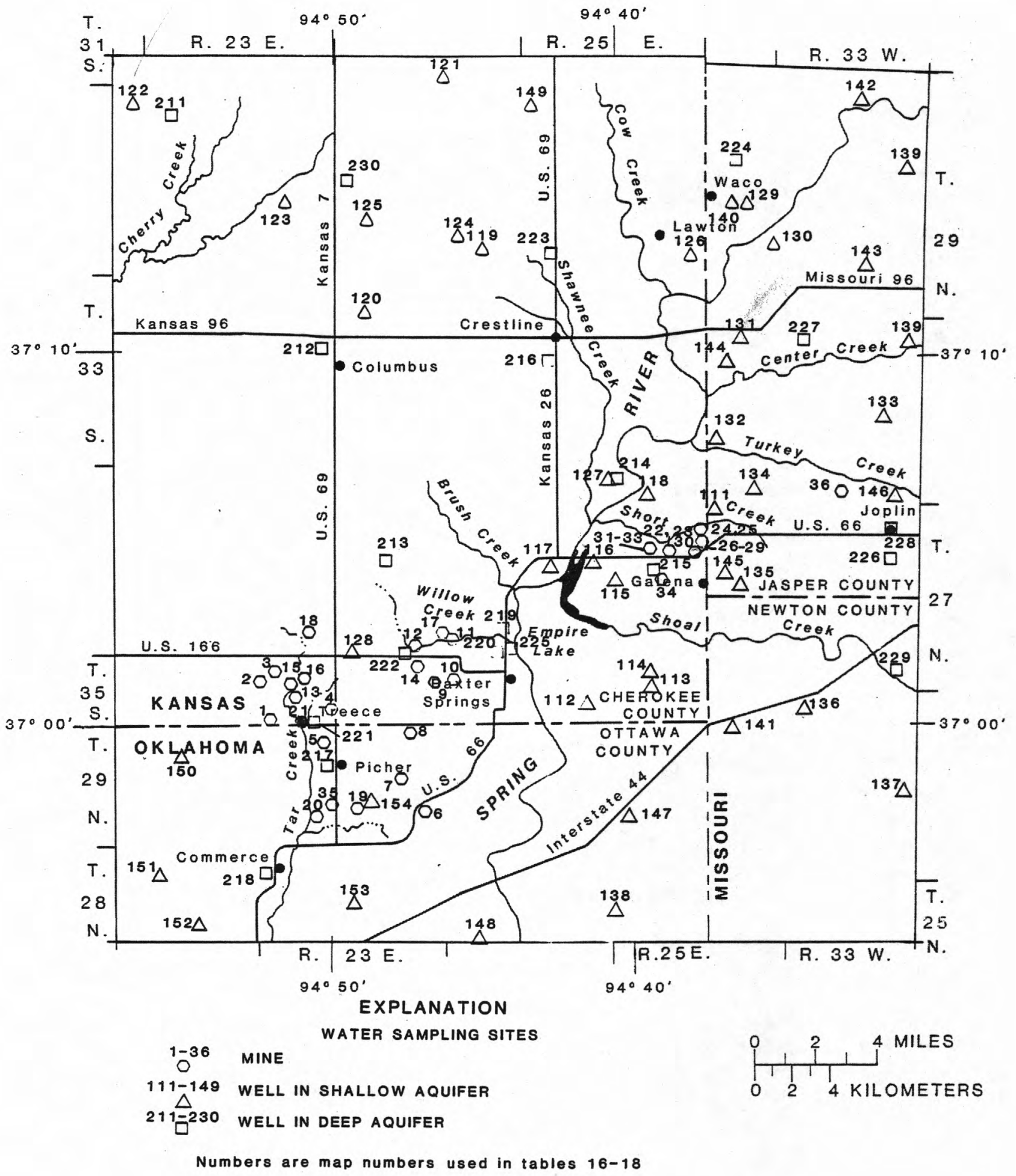

Figure 3.--Location of ground-water sampling sites. 


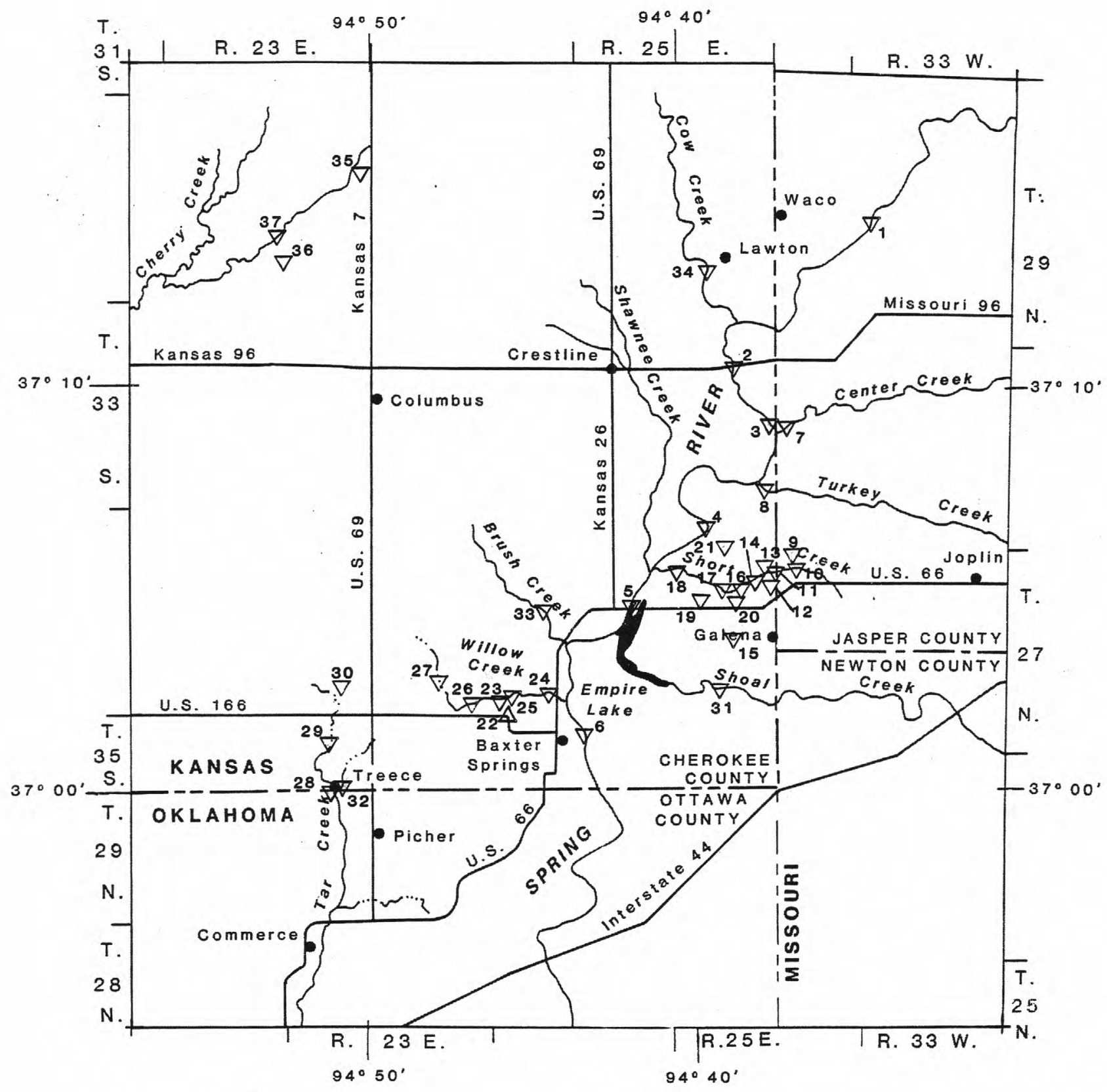

EXPLANATION

${ }^{27} \nabla$ SURFACE-WATER SAMPLING SITE--Number

is map number used in table 19

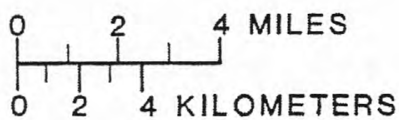

2

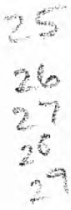

3

33 Figure 4.--Location of surface-water sampling sites. 


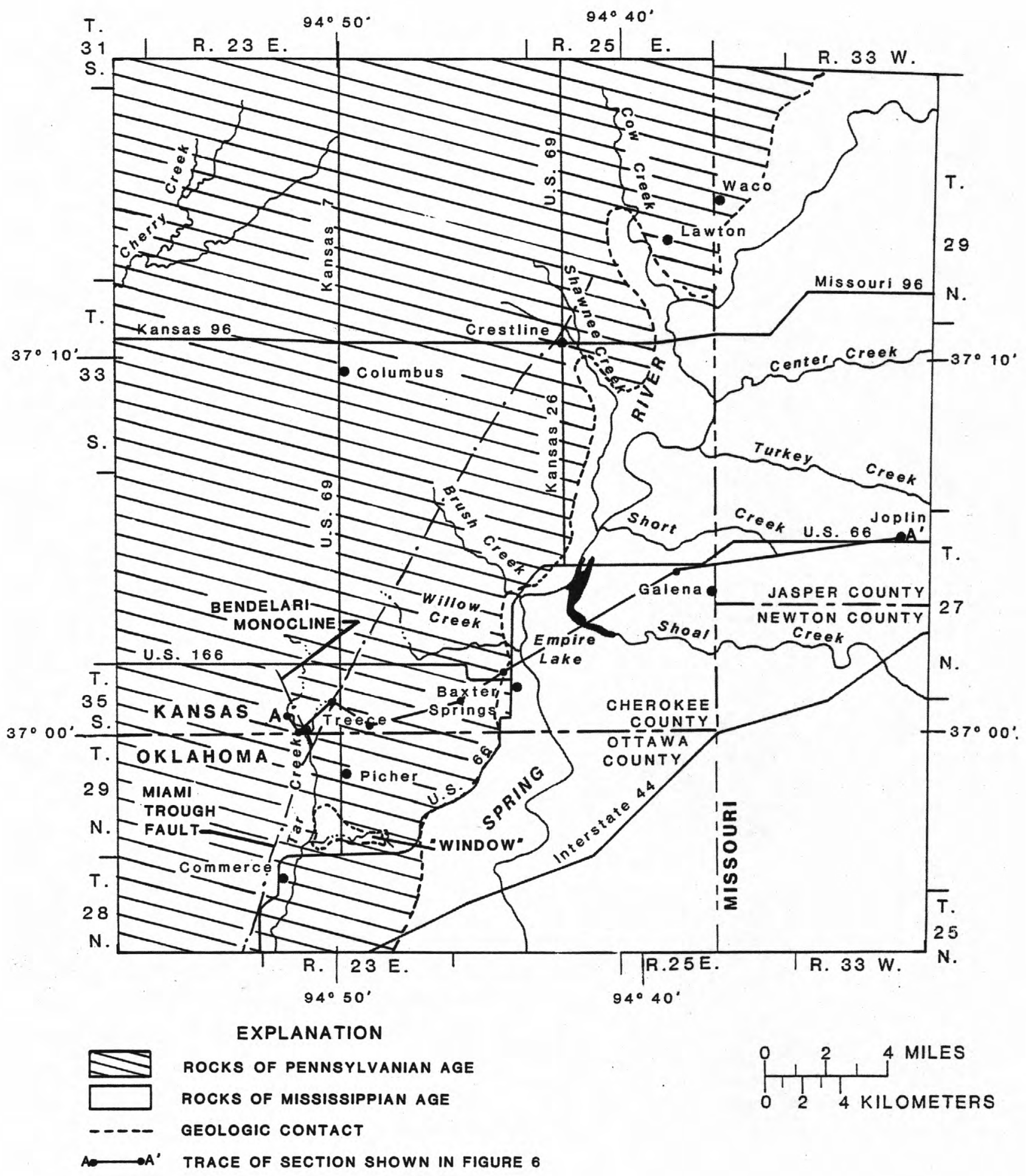

Figure 5.--Generalized geologic features of study area (modified from
Brichta, 1960). 
from Cherry Creek, located in the northwestern part, and from Tar Creek, which drains the western edge of the Picher lead-zinc field in the study area. Principal tributaries to the Spring River in the western area are Cow, Shawnee, Brush, and Willow Creeks. Land-surface elevations range from approximately 950 feet above the National Geodetic Vertical Datum of 1929 on hilltops to less than 800 feet in stream valleys.

The Ozark Plateau Province includes the area east of the PennsylvanianMississippian contact and is drained by the Spring River, which is approximately parallel to the contact (fig. 5). This area will be referred to as the eastern area. Land-surface elevations range from approximately 790 feet in the Spring River valley near the western edge of the province to more than 1,100 feet in the eastern part. Principal tributaries to the Spring River in the eastern area include Shoal, Short, Turkey, and Center Creeks.

Land use in the study area is primarily agricultural crop- or pastureland with scattered deciduous woodland. Large areas of mined land are found around Treece and Galena, Kansas, between Joplin, Missouri, and Galena, Kansas, and between Miami, Quapaw, and Picher, Oklahoma.

Soils in the study area are of three major associations. The Bodine-Baxter association is composed of deep, gently sloping soils with clayey subsoil and cherty soils weathered from underlying cherty limestones of Mississippian age. These soils coincide with the Ozark Plateau Province. The Parsons-Dennis association is a nearly level claypan formed primarily from weathered shales of Pennsylvanian age. The lead-zinc mined area west of Baxter Springs occurs in areas having this association, which generally coincides with the Central Lowlands Province. The Dennis-Bates association, a deep, sloping soil with clayey and loamy subsoils, is derived from weathered Pennsylvanian-age shales and sandstones and occurs in the northwestern quarter of the study area (U.S. Soil Conservation Service, 1972).

Predominant rocks in the study area are of Paleozoic age. These sedimentary rocks range in thickness from less than 1,200 feet in areas of granitic basement-rock highs to more than 2,000 feet. Outcropping and subcropping bedrock and structural features are shown in figure 5 . Regional dip of beds is toward the west and northwest. The westward dip of the rocks from Joplin, Missouri, to Treece, Kansas, is shown in figure 6 . The principal outcropping rocks are Pennsylvanian shales west of the Spring River and Mississippian limestones east of the Spring River. The major structural feature is the Miami trough (fig. 5). This trough and associated faults trend northeast from just west of Commerce, Oklahoma, to near Crestline, Kansas. The Bendelari trough trends (fig. 5) from the southeast to northwest and is well defined on the northwest side of the Miami trough. The stratigraphic sequence, lithology, range of thicknesses, water-bearing properties, and estimated hydrautic properties of principal geologic units in the study area are summarized in table 4.

Water supplies for public, rural domestic, stock, and irrigation purposes are derived primarily from ground water contained in rocks underlying 


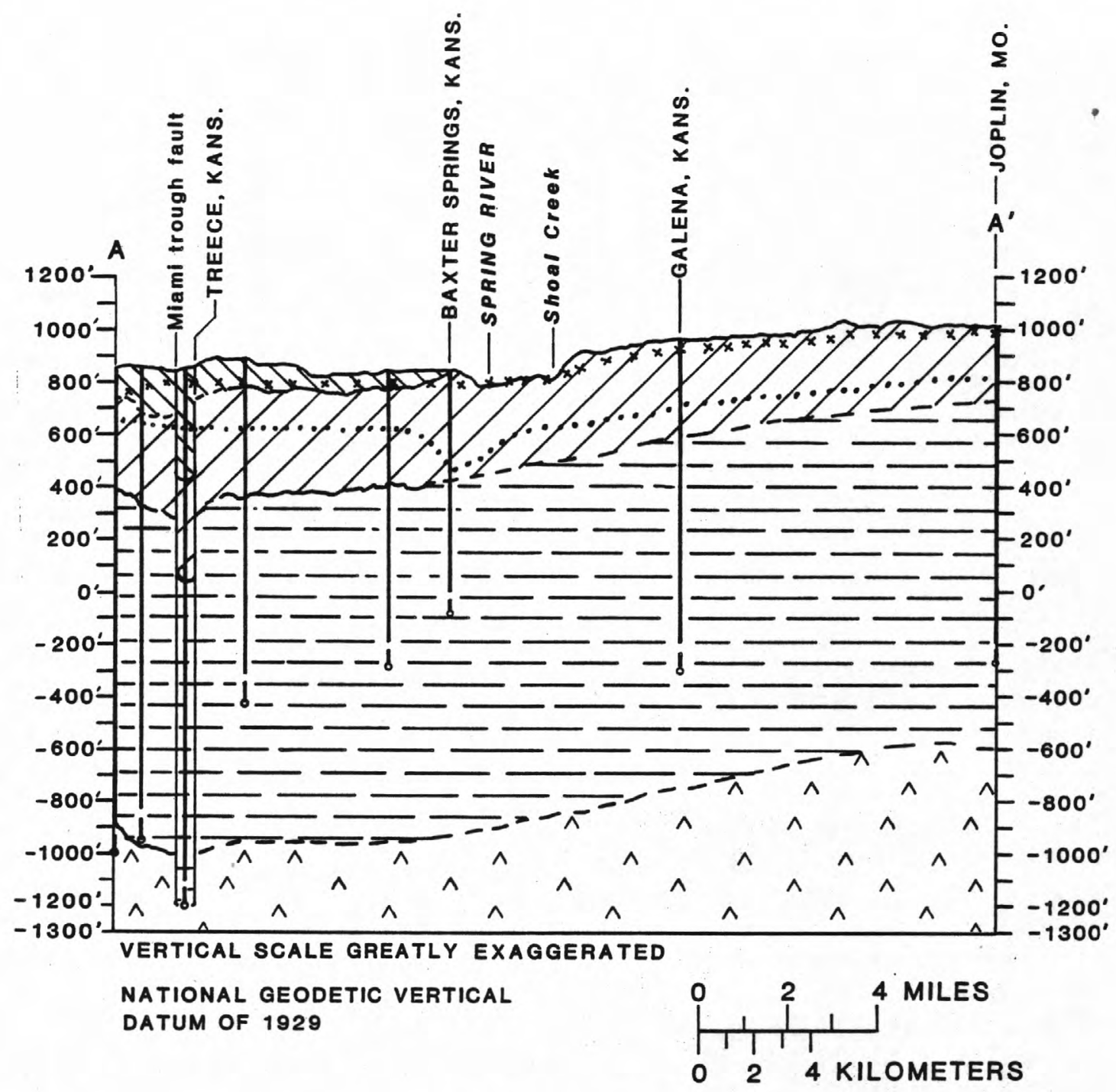

EXPLANATION
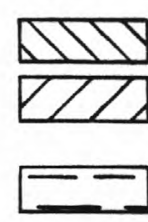

$\wedge \wedge \wedge$
PENNSYLVANIAN ROCKS

MISSISSIPPIAN ROCKS (Shallow aquifer)

CAMBRIAN AND ORDOVICIAN ROCKS (Deep aquifer)

PRECAMBRIAN ROCKS
- - GEOLOGIC CONTACT--

Dashed where inferred

$\star \times \times \times$ POTENTIOMETRIC SURFACE OF SHALLOW AQUIFER

- - POTENTIOMETRIC SURface OF DEEP AQUIFER

WELL OR BOREHOLE LOG

Figure 6.--Geologic section from near Treece, Kansas, to Joplin, Missouri. Trace of section shown in figure 5 . Potentiometric surfaces based on measured or reported water levels.

the study area. Based on water-use data from 1976-77 (U.S. Soil Conservation Service and the Kansas Water Resources Board, 1980), total water use for these purposes in Cherokee County, Kansas, was 1,042.8 million gallons, with approximately 928 million gallons, or 89 percent, supplied from deep wells drawing water primarily from Cambrian-Ordovician age rocks. These wells provide water for principal towns and surrounding rural areas. Water for 
the rural areas is distributed through rural water districts, which were established in the early 1960's. Based on estimates of unserved population in the townships, 11 percent of water supplied was from sources other than deep wells. Of this 11 percent, approximately 65.5 million gallons, or 6 percent, were obtained from the Lowell and Garden Townships east of the Spring River. Most of this water is probably obtained from wells developed into rocks of Mississippian age with some from alluvial deposits of Pleistocene age. The remaining 5 percent probably is derived from dug wells in rocks of Pennsylvanian age in the remaining townships west of the Spring River.

\section{METHODS}

Sample Collection and Laboratory Procedures

Samples were prepared and analyzed according to methods described by the American Public Health Association (1975) for inorganic constituents. Detection limits and reporting units for chemical constituents or physical properties analyzed are given in table 25 at the end of this report. Values that are less than the detection limit were reported as zero. Surface-water samples were collected according to methods described in Brown and others (1970). Samples were obtained from wells according to methods described in Wood (1976). Samples were obtained from mines by lowering a nonmetallic acrylic bottle into mine shafts or drill holes and closing the sampler at the desired depth. All ground-water and mine-water samples were filtered through a 0.45-micron millipore filter. Onsite measurements for dissolved oxygen, temperature, specific conductance, and $\mathrm{pH}$ were obtained from the mines using a Hydrolab or Ocean Data Aquameterl/ . unit equipped with 270 feet of cable and a multisensor probe. Alkalinity determinations were made on samples within 1 to 3 days after collection. Sample bottles for alkalinity were filled to the top, excluding air, tightly capped, and chilled until the time of determination. All chemical analyses were performed by the Division of Laboratories, Kansas Department of Health and Environment, Topeka, Kansas.

Water levels from mines and wells used for constructing the potentiometric-surface maps were obtained between July 1981 and March 1982, in the mined areas around Galena and between Treece and Baxter Springs, Kansas. For surrounding areas, available historical water-level information was used. Altitudes were obtained from topographic maps at most sites, although levels were run at selected sites as control points. Accuracy of water levels for this study are reported to the nearest 5 feet. At four sites selected as controls, measurements using topographic maps for altitude measurements were within 2 feet of altitudes established using levels.

1 The use of brand names in this report is for identification purposes only and does not imply endorsement by the U.S. Geological Survey or the Kansas Department of Health and Environment. 
Table 4.--Generalized section of geologic formations and their estimated hydraulic properties

[Hydraulic properties for Arbuckle formations are derived from specific-capacity data tabulated by Robertson 1963) for wells in Missouri. Storage coefficient was computed based on the method described by Lohman (1979). Median and ranges of transmissivity for each stratigraphic unit were computed from Meyer (1963, fig. 100)]

\begin{tabular}{|c|c|c|c|c|c|c|c|c|}
\hline $\begin{array}{l}\text { SYS- } \\
\text { TEM }\end{array}$ & SERIES & $\begin{array}{l}\text { Strati- } \\
\text { graphic } \\
\text { unit }\end{array}$ & $\begin{array}{c}\text { Lithology } \\
\text {. }\end{array}$ & $\begin{array}{c}\text { Thickness } \\
\left(\begin{array}{c}\text { in feet) } \\
\text { median, } \\
\text { range, } \\
\text { [] number } \\
\text { of logs }\end{array}\right.\end{array}$ & $\begin{array}{l}\text { Water-bearing } \\
\text { properties }\end{array}$ & 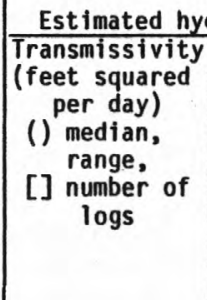 & $\begin{array}{l}\text { draulic pro } \\
\text { Storage } \\
\text { coeffi- } \\
\text { cient } \\
\text { (unitless) }\end{array}$ & \begin{tabular}{|c} 
Specifies \\
capacity \\
(unit- \\
less) \\
(1) median \\
range, \\
[] number \\
of \\
logs
\end{tabular} \\
\hline 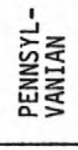 & 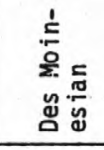 & $\begin{array}{l}\text { Undiffer- } \\
\text { entiated }\end{array}$ & $\begin{array}{l}\text { Shales and sandstones } \\
\text { with beds of coal. }\end{array}$ & $0-450$ & $\begin{array}{l}\text { Yields small supplies } \\
\text { for domestic and stock } \\
\text { uses; less than } 10 \\
\text { gallons per minute. }\end{array}$ & No data & No data & No data \\
\hline \multirow{6}{*}{ 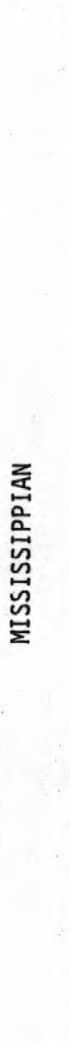 } & 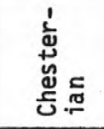 & $\begin{array}{l}\text { Undiffer- } \\
\text { entiated }\end{array}$ & $\begin{array}{l}\text { Limestones, shales, } \\
\text { and siltstones. }\end{array}$ & $\begin{array}{c}(0) \\
0-120 \\
{[10]}\end{array}$ & $\begin{array}{l}\text { Does not yield water } \\
\text { to wells. }\end{array}$ & No data & No data & No data \\
\hline & 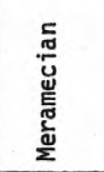 & $\begin{array}{l}\text { Warsaw } \\
\text { Lime- } \\
\text { stone }\end{array}$ & $\begin{array}{l}\text { Crinoidal limestone } \\
\text { with chert. Localized } \\
\text { outcrops at topographic } \\
\text { highs around Galena, } \\
\text { Kansas }\end{array}$ & $\begin{array}{c}(65) \\
0-180 \\
{[8]}\end{array}$ & \multirow{3}{*}{$\begin{array}{l}\text { yields little } \\
\text { water where } \\
\text { massive, put } \\
\text { yields adequate } \\
\text { to good supplies } \\
\text { from solution } \\
\text { channels, breccia, } \\
\text { and fractures. }\end{array}$} & \multirow{3}{*}{$\begin{array}{l}\text { Less than } \\
100 \text { where } \\
\text { massive; } \\
\text { greater than } \\
1,000 \text { in } \\
\text { brecciated } \\
\text { areas }\end{array}$} & \multirow[t]{3}{*}{$\begin{array}{l}2 \times 10^{-4} \\
\text { where } \\
\text { uncon- } \\
\text { fined }\end{array}$} & \multirow[t]{3}{*}{ No data } \\
\hline & \multirow[b]{2}{*}{ 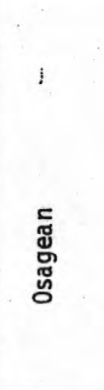 } & $\begin{array}{l}\text { Undiffer- } \\
\text { entiated } \\
\text { Burlington } \\
\text { and } \\
\text { Keokuk } \\
\text { Limestone }\end{array}$ & $\begin{array}{l}\text { Coarse crystalline } \\
\text { crinoidal limestone } \\
\text { with chert. }\end{array}$ & $\begin{array}{l}(115) \\
20-240 \\
{[9]}\end{array}$ & & & & \\
\hline & & $\begin{array}{l}\text { Fern Glen } \\
\text { Limestone }\end{array}$ & $\begin{array}{l}\text { Dolomitic limestone } \\
\text { in lower strata and } \\
\text { limestone with abun- } \\
\text { dant chert in upper } \\
\text { strata. }\end{array}$ & $\begin{array}{c}(160) \\
120-200 \\
{[6]}\end{array}$ & & & & \\
\hline & \multirow[b]{2}{*}{ 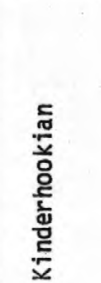 } & $\begin{array}{l}\text { Northview } \\
\text { Shale }\end{array}$ & $\begin{array}{l}\text { Calcareous gray-green } \\
\text { shale. }\end{array}$ & $\begin{array}{r}(15) \\
0-55 \\
{[9]}\end{array}$ & $\begin{array}{l}\text { Does not yield water } \\
\text { to wells. }\end{array}$ & No data & No data & No data \\
\hline & & $\begin{array}{l}\text { Compton } \\
\text { Limestone }\end{array}$ & $\begin{array}{l}\text { Textured greenish-gray } \\
\text { shaly limestone; } \\
\text { generally chert free. }\end{array}$ & $\begin{array}{r}(12) \\
0-25 \\
{[7]}\end{array}$ & $\begin{array}{l}\text { Does not yield water } \\
\text { to wells. }\end{array}$ & No data & No data & No data \\
\hline
\end{tabular}




\begin{tabular}{|c|c|c|c|c|c|c|c|c|c|c|}
\hline 离 & \multicolumn{2}{|c|}{ 造 } & \multirow{2}{*}{ 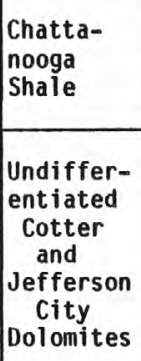 } & \multirow{2}{*}{$\begin{array}{l}\text { Fissile black shale; } \\
\text { generally not present } \\
\text { in study area. } \\
\begin{array}{l}\text { Cherty, dol omite and } \\
\text { sandstones and } \\
\text { partings of brown- } \\
\text { green shale. }\end{array}\end{array}$} & \multirow{2}{*}{$\begin{array}{c}0-10 \\
\\
\begin{array}{c}(360) \\
170-550 \\
{[9]}\end{array}\end{array}$} & \multicolumn{2}{|c|}{$\begin{array}{l}\text { Does not yield water } \\
\text { to wells. }\end{array}$} & \multirow{2}{*}{$\begin{array}{c}\text { No data } \\
\\
1 /(400) \\
70-940 \\
{[5]}\end{array}$} & \multirow{2}{*}{$\begin{array}{l}\text { No data } \\
3 \times 10^{-4}\end{array}$} & \multirow{2}{*}{$\begin{array}{l}\text { No dat } \\
\\
\begin{array}{c}(1.5) \\
0.2-3.1 \\
{[5]}\end{array}\end{array}$} \\
\hline 怘 & \multirow{3}{*}{ 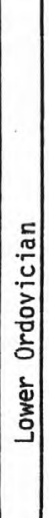 } & \multirow{3}{*}{ 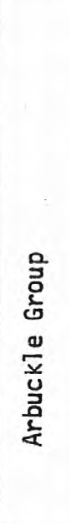 } & & & & \multirow{6}{*}{ 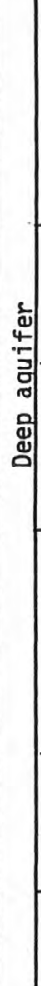 } & $\begin{array}{l}\text { Yields small quan- } \\
\text { tities of water } \\
\text { to wells. }\end{array}$ & & & \\
\hline & & & $\begin{array}{l}\text { Roubidoux } \\
\text { Formation }\end{array}$ & $\begin{array}{l}\text { Sandy dolomite with } \\
\text { chert. }\end{array}$ & $\begin{array}{c}(170) \\
120-200 \\
{[11]}\end{array}$ & & $\begin{array}{l}\text { Yields good sup- } \\
\text { lies of water to } \\
\text { wells. }\end{array}$ & $\begin{array}{c}(670) \\
14-27,000 \\
{[14]}\end{array}$ & $5 \times 10^{-4}$ & $\begin{array}{l}(2.0) \\
0.1 \\
{[14]}\end{array}$ \\
\hline & & & $\begin{array}{l}\text { Gasconade } \\
\text { Dolomite }\end{array}$ & $\begin{array}{l}\text { Light-gray coarse crys- } \\
\text { talline dolomite; lower } \\
\text { part composed of sandy } \\
\text { dolomite. }\end{array}$ & $\begin{array}{c}(250) \\
165-320 \\
{[10]}\end{array}$ & & $\begin{array}{l}\text { Yields adequate to } \\
\text { good supplies of } \\
\text { water to wells. }\end{array}$ & $\begin{array}{c}(1,070) \\
30-30,000 \\
{[52]}\end{array}$ & $7 \times 10^{-4}$ & $\begin{array}{l}(5) \\
0.3-1 \\
{[52]}\end{array}$ \\
\hline \multirow{3}{*}{ 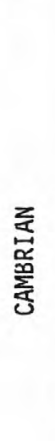 } & \multirow{3}{*}{ 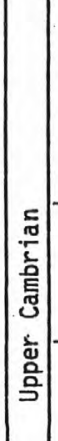 } & & $\begin{array}{l}\text { Eminence } \\
\text { Dolomite }\end{array}$ & $\begin{array}{l}\text { Medium to massive bed- } \\
\text { ded light-gray coarse- } \\
\text { grained dolomite. } \\
\text { Small amounts of chert } \\
\text { in upper section. } \\
\text { Glauconite present. }\end{array}$ & $\begin{array}{c}(160) \\
120-210 \\
{[9]}\end{array}$ & & $\begin{array}{l}\text { Yields adequate to } \\
\text { good supplies of } \\
\text { water to wells. }\end{array}$ & $\begin{array}{c}(1,400) \\
13-20,000 \\
{[37]}\end{array}$ & $9 \times 10^{-4}$ & $\begin{array}{r}(5.1) \\
0.2-56\end{array}$ \\
\hline & & & $\begin{array}{l}\text { Bonne- } \\
\text { terre } \\
\text { Dolomite }\end{array}$ & $\begin{array}{l}\text { Medium to fine crystal- } \\
\text { line dark gray-brown } \\
\text { dolomite. }\end{array}$ & $\begin{array}{c}(170) \\
140-230 \\
{[9]}\end{array}$ & & $\begin{array}{l}\text { Yields small to } \\
\text { good supplies of } \\
\text { water to wells. }\end{array}$ & No data & $1 \times 10^{-3}$ & $\begin{array}{l}\text { No } \\
\text { data }\end{array}$ \\
\hline & & & $\begin{array}{l}\text { Reagan } \\
\text { Sandstone }\end{array}$ & & & & & & $1 \times 10^{-3}$ & $\begin{array}{l}\text { No } \\
\text { data }\end{array}$ \\
\hline \multicolumn{4}{|c|}{ PRECAMBRIAN } & Granites and rhyolites. & \multicolumn{3}{|c|}{$\begin{array}{l}\text { Does not yield water } \\
\text { to wells. }\end{array}$} & No data & No data & $\begin{array}{l}\text { No } \\
\text { data }\end{array}$ \\
\hline
\end{tabular}

1 Values shown for estimated hydraulic properties for Arbuckle Group formations are cumulative and are representative of the interval from the Cotter and Jefferson City Dolomites to the stratigraphic unit for which the value is given. 
Chemical-quality data were summarized for each station by first computing median values for each chemical constituent or property. This technique prevents weighting of values from a single sample point with several measurements. Data from mines, wells, and streams (tables 20-24 at the end of this report) then were summarized based on two areal divisions, east and west of the Pennsylvanian-Mississippian contact.

Historical chemical-quality data from previous reports by Feder and others (1969) and Barks (1977) in Missouri and by Havens (1978) in Oklahoma were used in the discussion of ground-water quality in the shallow and deep aquifers. An asterisk in the last column of tables 16-18 (see section entitled "Supplemental Information" at the end of the report) indicates that the sample was collected for the current study and that the analys is is published in this report. For those sites having no asterisk, but which indicate that a chemical analysis is available, the reader is referred to the reports cited above or to NAWDEX (National Water Data Exchange) to obtain the information from the U.S. Geological Survey's WATSTORE waterquality file.

Previously unpublished chemical water-quality data from wells in the shallow and deep aquifer in the western area were used in the discussion on ground-water quality and in the statistical summaries for water quality in the shallow aquifer for the western area shown in table 6 of this report (p. 35). Data from these sites are presented in table 24 near the end of this report.

\section{HYDROGEOLOGY}

\section{Ground Water}

Two major aquifer systems, referred to as the shallow and deep aquifers, are present in the study area. Rocks of Mississippian age, referred to as the shallow aquifer by Feder and others (1969) and Barks (1977), provide water for rural domestic and stock supplies in the eastern part of the study area. Few wells are completed in Mississippian-age rocks in the western area, generally because better quality water is available through rural water districts from deep wells in the Cambrian- and Ordovician-age rocks. Rocks of Cambrian and Ordovician age, which provide the principal source of water for public, industrial, domestic, and stock supplies in Cherokee County and adjacent areas in southwestern Missouri and northeastern Oklahoma, were referred to by Feder and others (1969) and Barks (1977) as the deep aquifer.

\section{Shallow Aquifer}

Limestones of Mississippian age constitute the shallow aquifer. A major part of these water-bearing rocks occurs from the Warsaw Limestone to the base of the Fern Glen Limestone (table 4). This entire section, composed of Meramecian and Osagean Series rocks, corresponds to the Boone Formation that is referred to in OKlahoma and Missouri reports. 
In the eastern area, the shallow aquifer generally follows the topography and grossly exhibits unconfined, or water-table conditions, whereby the water-table configuration is controlled by surface streams (Harvey and Emmett, 1980, p. 26; al so see fig. 9). However, the shallow aquifer is hydraulically very heterogeneous. Brecciated zones, with which ore deposits are associated, occur in localized areas of less than an acre to several square miles throughout much of the area in Missouri (Harvey and Emmett, 1980, p. 15) and in Kansas (Haworth, 1904, p. 113). The largest brecciated zone in the eastern area in Kansas occurs in an approximately 5-square-mile area in the vicinity of Galena, Kansas (fig. 7). The brecciated zones, which consist of very fractured, porous material, have much higher transmissivities than the surrounding limestone areas (Harvey and Emmett, 1980, p. 14; Feder and others, 1969, p. 22), and movement of water is more rapid and regular than in the limestone. Water-table conditions occur in these brecciated zones (Feder and others, 1969, p. 27). The limestone areas exhibit confined conditions (Feder and others 1969, p. 27), and movement of water in the limestone is irregular and controlled by fractures, bedding planes, and solution channels.

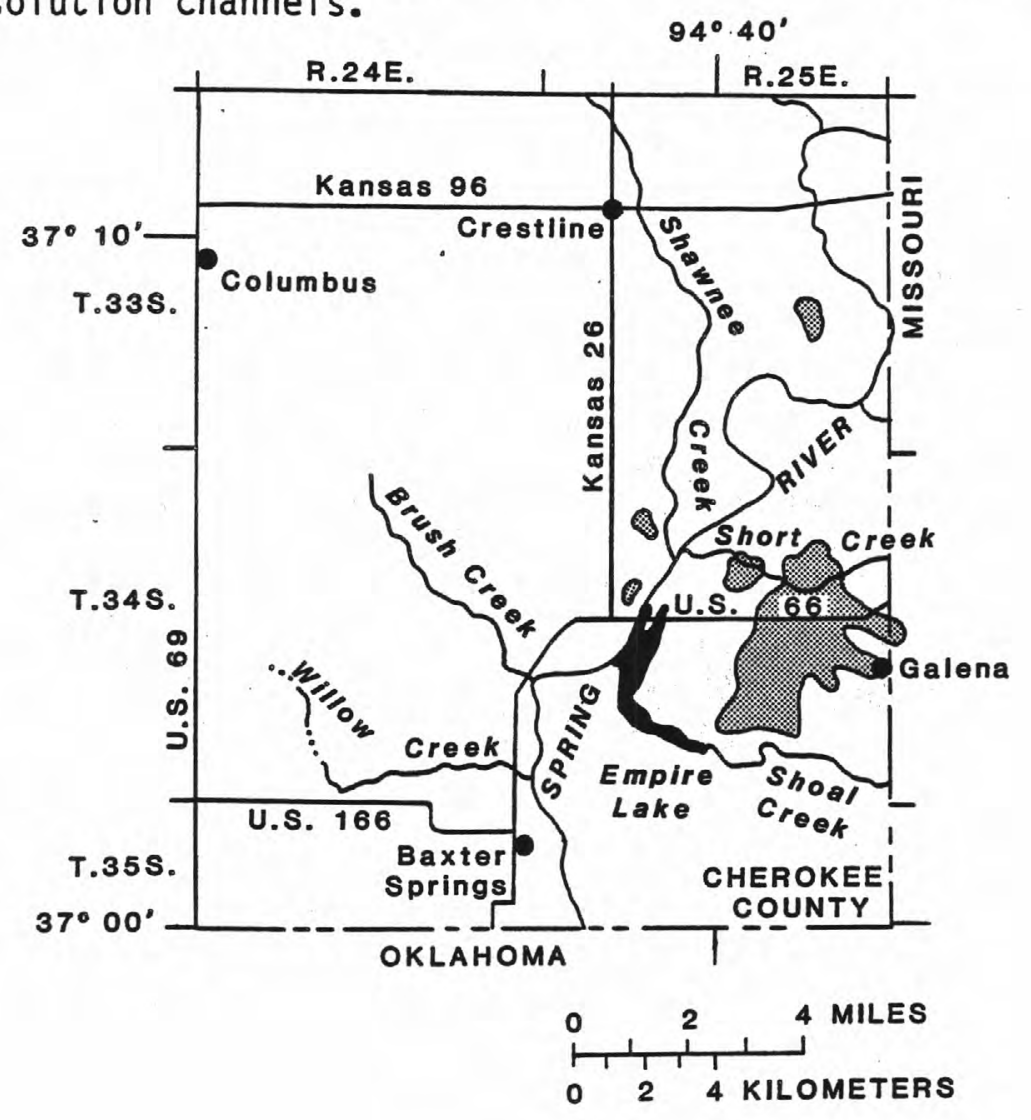

EXPLANATION

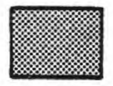

BRECCIATED ZONE

Figure 7.--Location of major brecciated zonẹs in eastern area of Kansas (modified from Haworth, 1904). 
General hydrologic characteristics of the shallow aquifers in the eastern area in Kansas are shown in figure 8. Extensive brecciated chert zones and mines are located in approximately 60 percent of the 3.5 miles of the Short Creek channel in Kansas (fig. 7). Ground water in the mines and in breccia in the Short Creek valley is generally under water-table conditions, as shown in figure 8. Ground water discharges to Short Creek, as indicated by the upvalley deflection of the water-table contours (see fig. 9) and by the downstream gain in discharge during August 1981 (see fig. 19). Ground water in the breccia and mines is recharged partially by drainage from chat, small tributaries to Short Creek, and drainage ditches. The discharges of many small streams, which flowed for several days after late spring rains, were observed by the author to disappear beneath the land surface or enter the mines directly. The amount of groundwater inflow to the mines and breccia from the surrounding limestones is controlled by the permeability of the limestones (Feder and others, 1969, p. 22).

In predominantly limestone areas surrounding the brecciated zones, such as near Shoal Creek (fig. 8), ground water is under confined conditions. In Shoal Creek, ground water discharges to the creek through seeps, springs, and abandoned wells when the potentiometric surface drops-below the land surface during wet periods (fig. 8A). Wells and some springs may cease discharge to the creek when the potentiometric surface drops below the land surface during dry periods (fig. $8 \mathrm{~B}$ ).
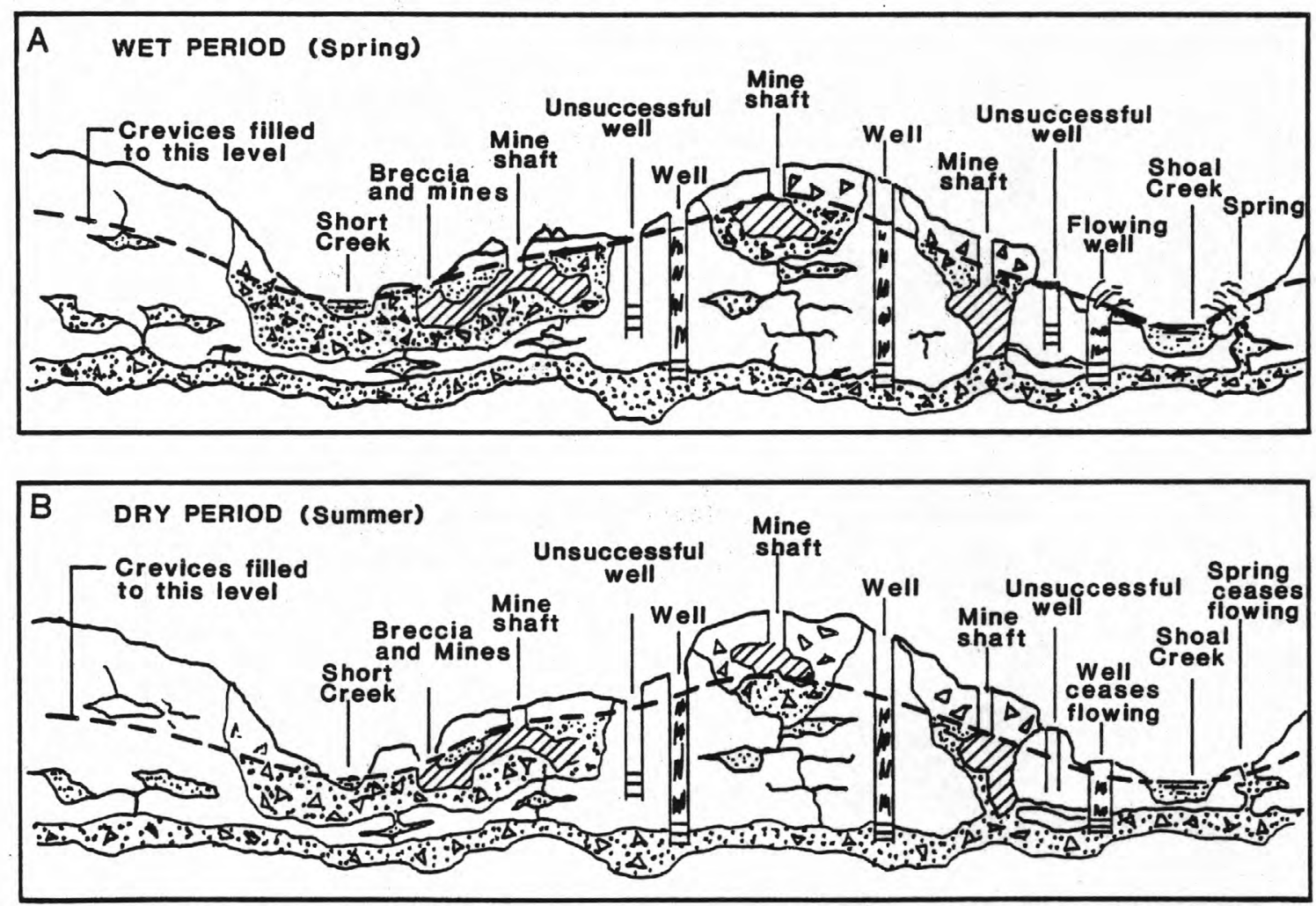

NOT TO SCALE

Figure 8.--Generalized hydrologic characteristics of shallow aquifer in eastern part of study area. (A) represents a wet period, and (B) represents a dry period. Aquifer is unconfined in breccia and mines and confined away from these areas. Shaded areas indicate presence of water. 
In the western area, the shallow aquifer is confined by shales of Pennsylvanian age or possibly Upper Mississippian rocks of the Chesterian Series, except where there are discontinuities or perforations in the shale (see fig. 12). Discontinuities or perforations in the shale may be due either to mine-related collapses, shafts, or drill holes or to natural erosional processes. An example of an area where the shale is absent due to natural erosional processes is a "window" in the shale located just west of Quapaw, Oklahoma, as shown in figure 5.

Variability in transmissive characteristics of the shallow aquifer may be observed in terms of its water-yielding properties. Well yields in limestones in Jasper and Newton Counties, Missouri, ranged from 2 to 390 gal/min, with a median of 20 gal/min (Harvey and Emmett, 1980, p. 17). Yields from wells completed in mines that are located in brecciated zones, however, were significantly larger; yields from Missouri ranged from 100 to 1,500 gal/min (Feder and others, 1969, p. 32), whereas yields west of Baxter Springs, Kansas, ranged from 1,000 to 2,000 gal/min (Abernathy, 1943, p. 234; Reed and others, 1955, p. 115). Estimates of hydraulic properties of the shallow aquifer are given in table 4 .

Using estimates of the saturated thickness, porosity, and storage coefficient of the aquifer, ground water in storage may be approximated. Cumulative median thickness for the undifferentiated Burlington-Keokuk and Fern Glen Limestones, which are present throughout the study area, is 275 feet (see table 4). In order to provide a conservative estimate, 200 feet of saturated thickness was assumed. Porosity estimates for rocks in the Boone Formation in Oklahoma ranged from 1.2 to 8.9 percent (Manger, 1963, see page E46 for method of porosity determination), with a mean value of 5.2 percent and a standard deviation of 3.7. Because large areas of breccia are scattered throughout the shallow aquifer, a slightly larger value of between 5 and 9 percent, or 7 percent, was used. The storage coefficient for the confined shallow aquifer was estimated, from a technique described by Lohman (1979, p. 53), to be approximately $2^{2} \times 10^{-4}$, based on an average saturated thickness of 200 feet. Therefore, a gross estimate of the approximate amount of water in storage in the shallow aquifer in the 735square-mile study area is $2.15 \times 10^{12}$ gallons, or 7 million acre-feet. Water contained in the mines, based on volume estimates in this report, constitutes less than 2 percent of this total for the entire study area. Twenty-four percent of the water contained in mines within the study area is in Kansas.

The potentiometric surface of the shallow aquifer in Cherokee County and adjacent areas is shown in figure 9. Regional movement of water is westward from Missouri, with a northward component in southern Cherokee County, as indicated by the westward deflection of the 800-foot contour.

The major source of regional recharge to the shallow aquifer is precipitation falling on exposed Mississippian rocks east of the Pennsylvanian shale (fig. 5). Local recharge occurs in the western area through discontinuities in the shale, such as collapses, open drill holes located near streams, and possibly through the "window" Tocated west of Quapaw, Oklahoma. 


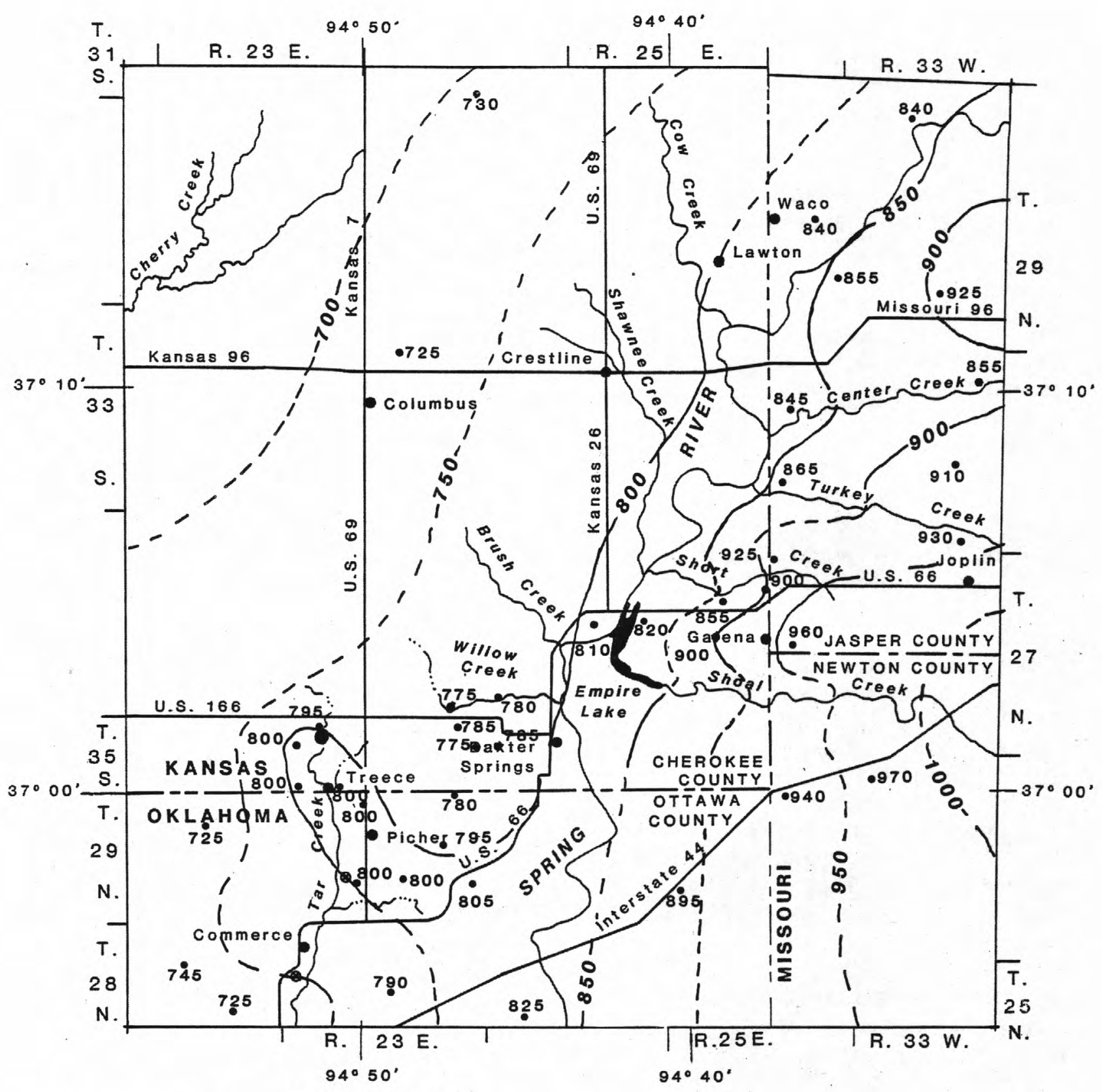

EXPLANATION

800 - - POTENTIOMETRIC CONTOUR--Shows altitude of 0224 MILES water level in mine shafts, drill holes and wells.

Dashed where inferred from historical data.

Contour interval 50 feet. National Geodetic

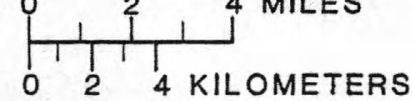

Vertical Datum of 1929

805 LOCATION OF WELL OR MINE--Number is altitude

of water level in feet. National Geodetic Vertical

Datum of 1929

COLLAPSE ON STREAMBED

GROUND-WATER DISCHARGE THROUGH DRILL HOLES AND SHAFTS

Figure 9.--Potentiometric surface of shallow aquifer. 
This is suggested by the presence of a ground-water mound in 0k1ahoma and southern Cherokee county (fig. 9). This mound also may be caused by the presence of the Miami trough (figs. 5 and 6), which could act as a partial boundary to flow due to displacement of Mississippian rocks. Sources of discharge in the eastern area are wells, seeps, surface streams, and springs, and visible sources of discharge in the western area are a few wells in Cherokee County, and open drill holes near Commerce, Oklahoma (fig. 9). The primary regional discharge area for water in the shallow aquifer is located outside of the study area, as the potentiometric surface declines in a westerly direction and is 100 feet or more below streambeds in the western area.

\section{Deep Aquifer}

The deep aquifer consists of dolomites and sandy dolomites of Cambrian and Ordovician age and extends from the Reagan Sandstone of Cambrian age, which lies on the Precambrian basement, to the Cotter Dolomite of Ordovician age. The Cotter Dolomite underlies either the Compton Limestone or the Northview Shale of Mississippian age (table 4) throughout most of the study area. The principal rock units tapped by most wells in the study area occur between the Eminence and Cotter Dolomites. Rocks between the Eminence and Cotter Dolomites are known collectively as the Arbuckle Group.

The deep aquifer is a confined system where the Chattanooga Shale (not present throughout most of the study area), Compton Limestone, or Northview Shale are present and a semiconfined system where they are not (MacFarlane and others, 1981). Storage-coefficient values derived from pump tests in OKlahoma and Kansas reported by MacFarlane and others (1981) are in the range expected for confined aquifers (between $10^{-5}$ and $10^{-3}$ ) (Lohman, 1979, p. 8). The deep aquifer is characterized by heterogeneous vertical and lateral hydraulic properties, which are caused by the presence of solution channels and fractures (MacFarlane and others, 1981). Estimates of hydraulic properties of the deep aquifer are given in table 4 .

Transmissive properties of the deep aquifer are variable, with largest transmissivities observed north of the study area. Transmissivity values calculated from specific-capacity data from 37 deep wells drawing water from the Arbuckle Group in Missouri (table 4) ranged from 13 to 20,000 $\mathrm{ft}^{2} / \mathrm{d}$. The median value calculated from data for these wells was 1,400 $\mathrm{ft}^{2} / \mathrm{d}$. Transmissivity values, reported by MacFarlane and others (1981) from 15 wells that occur within the boundary of the study area and are developed into rocks of Cambrian and Ordovician age, ranged from less than 100 to $100,000 \mathrm{ft} 2 / \mathrm{d}$. Eight wells, or 53 percent, had transmissivity values of less than $1,000 \mathrm{ft}^{2} / \mathrm{d}$.

A gross estimate of water stored in Arbuckle Group rocks in the deep aquifer is 14 trillion gallons or 42 million acre-feet. This estimate is based on cumulative median thicknesses of rock units in the Arbuckle Group 
(approximately 940 feet, see table 4) and an estimated porosity of 10 percent. Porosity values for Arbuckle Group rocks in Kansas ranged from 1.2 to 19.8 percent, with an average porosity of 10.3 percent (Manger, 1963, see $p$. E46 for description of method of porosity determination).

The potentiometric surface of the deep aquifer is shown in figure 10. Movement of water in the deep aquifer in the study area is westward from the eastern boundary of Cherokee County from recharge areas in Missouri, then southward across the southern part of Cherokee County towards Oklahoma. Precipitation falling on Cambrian and Ordovician rocks that outcrop east of the study area in Missouri on the western flank of the Ozark Dome (see Siebenthal, 1915; MacFarlane and others, 1981) is a major source of recharge to the deep aquifer.

In addition to recharge from precipitation on rock outcrops, the deep aquifer also may be recharged by leakage from the overlying shallow aquifer. Reed and others (1955) and Stramel (1957) hypothesized that the shallow and deep aquifers are hydraulically connected where the Chattanooga Shale is not present. The Chattanooga shale is not present throughout most of the study area, although the Northview Shale and Compton Limestone may act to varying degrees as confining layers. MacFarlane and others (1981) suggested that leakage of water from the shallow to the deep aquifer is likely where confining layers are not present and where the hydraulic head is greater in the shallow aquifer. By overlaying figures 9 and 10, differences in hydraulic head in the deep aquifer were determined to range from less than 50 feet to more than 400 feet bel ow that in the shallow (fig. 11), implying a potential for downward movement throughout most of the study area, with maximum potential in Ottawa County, Oklahoma.

Principal sources of discharge from the deep aquifer are public-supply and industrial wells in the study area. Annual pumpage for the entire study area is approximately $3.8 \times 10^{9}$ gallons or 11,660 acre-ft/yr, with 47 percent or 1.8 billion gallons in Oklahoma (R. W. Fairchild, U.S. Geological Survey, oral communi., 1983), about 26 percent or 1 billion gallons in Cherokee County, Kansas (U.S. Soil Conservation Service and Kansas Water Resources Board, 1980), and 1 billion gallons in Jasper and Newton Counties, Missouri (Gann and others, 1974).

\section{Effects of Abandoned Mines on Ground-Water Hydrology}

Past-mining activities and abandoned mines have affected both the regional and local hydrogeology in many ways. During active mining, the potentiometric surface of the shallow aquifer was lowered temporarily by pumping so that the mines could be worked. Pumping of the mines resulted in wells within and near the mining districts going dry. Hydraulic properties of the shallow aquifer were altered permanently as a result of ore extraction. The primary effects were creation of highly transmissive zones and increased ground-water storage properties of the aquifer due to enlarged void spaces created by removal of rock in the mine workings. Additionally, placement of fractured rock and porous tailings on the land 


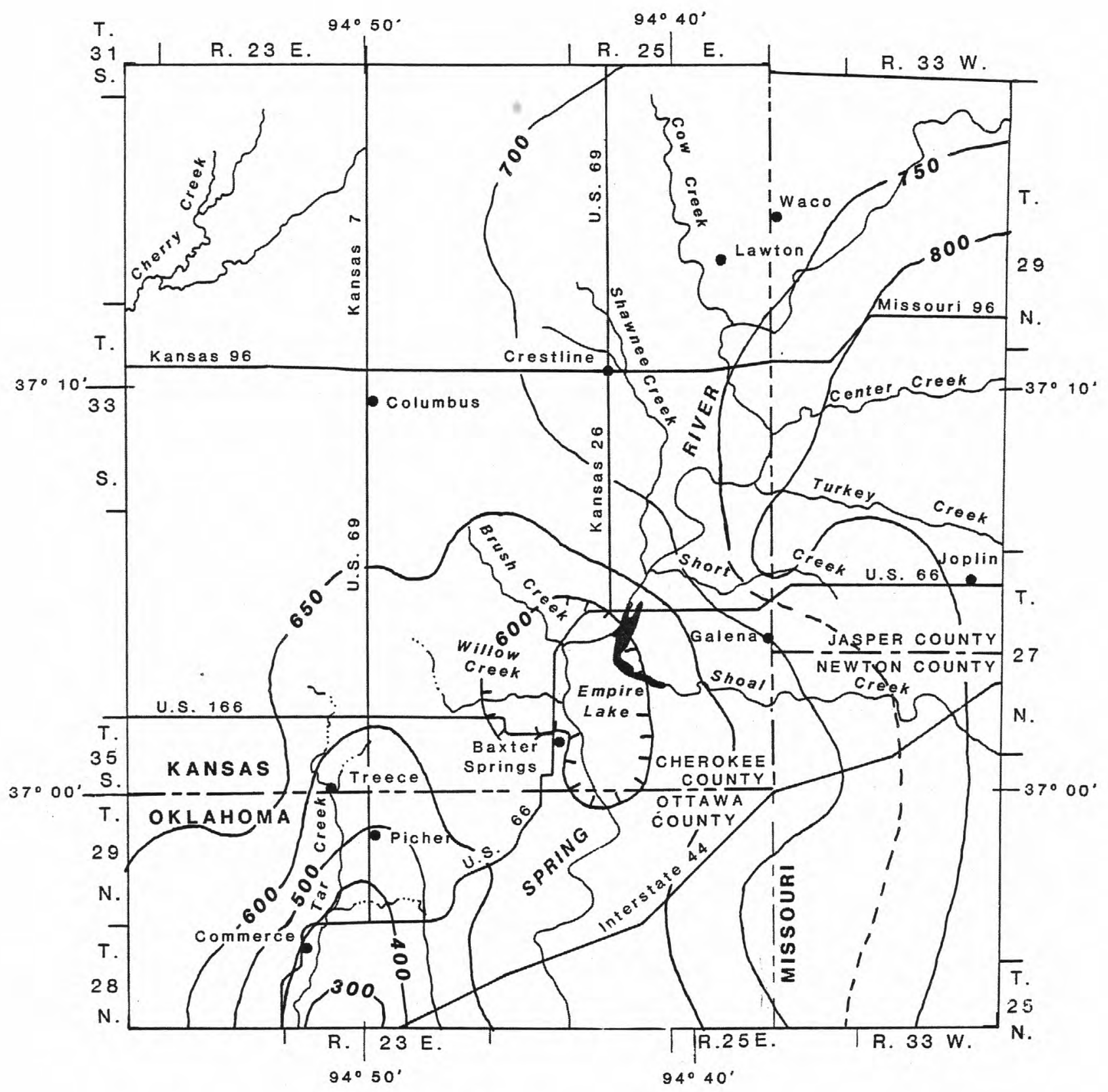

EXPLANATION

- 650 - - - POTENTIOMETRIC CONTOUR--Shows altitude of water level in wells. Dashed where inferred. Contour interval 50 and 100 feet. National

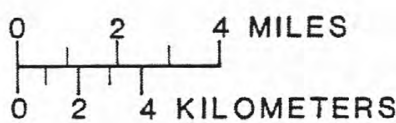

Geodetic Vertical Datum of 1929

Figure 10.--Potentiometric surface of deep aquifer (from Marcher and others, 1983). 


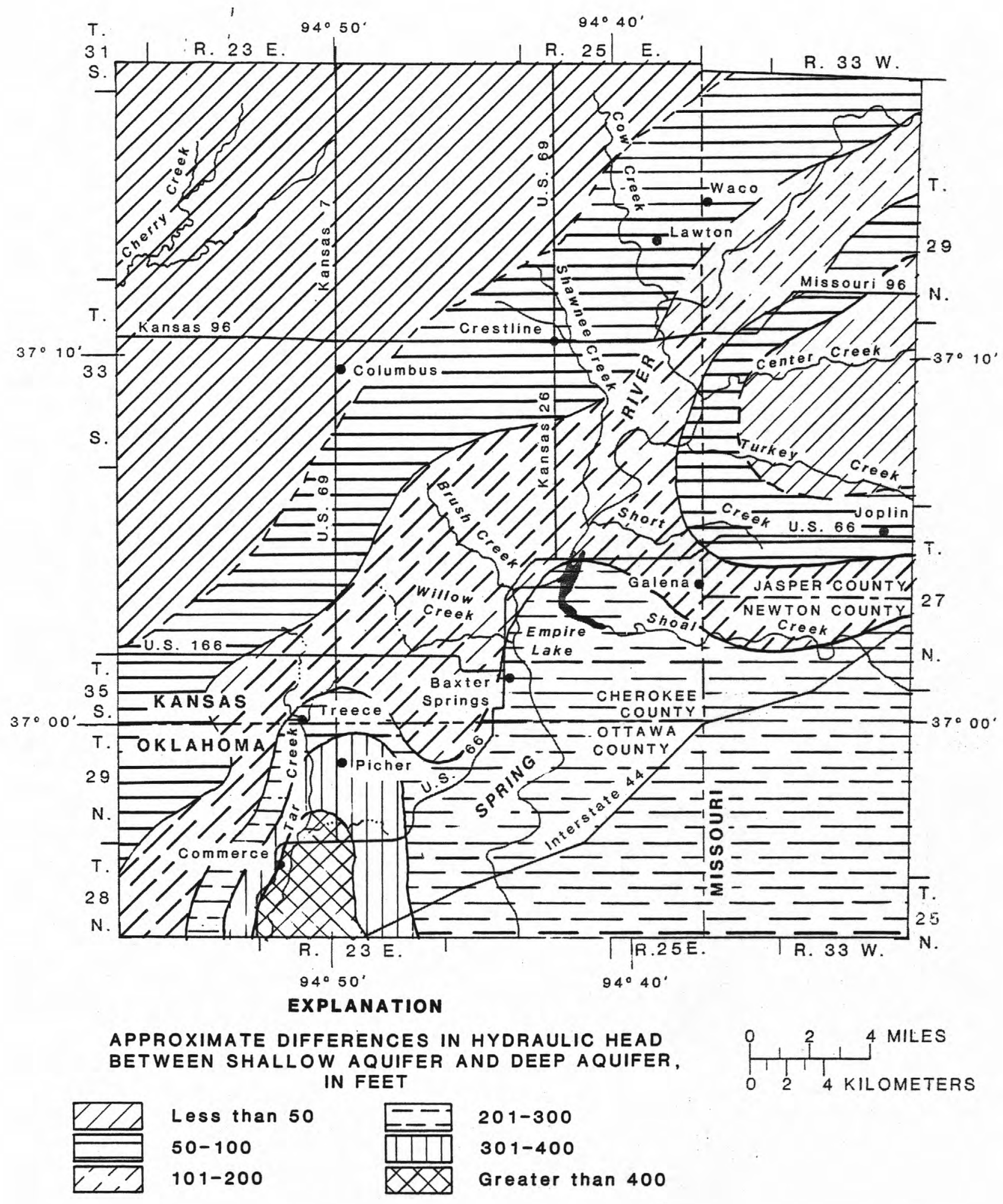

Figure 11.--Approximate differences in hydraulic head between shallow and deep aquifers. 
surface provided a medium for short-term water storage. In the eastern area, fractured rock and tailings increased the amount of water available for infiltration to the shallow aquifer; in the western area, tailings on the impermeable shales created artificially perched aquifer systems that slowly drain to surface streams. Also in the western area, artificialrecharge and discharge areas were created where the confining shale was breached by collapse of mine rooms, mine shafts, drill holes, or well bores. Recharge areas occur where the potentiometric surface of the shallow aquifer is below openings in the shale, which allows entry of surface water, particularly near stream channels [fig. 12 (C) and (D)]. Discharge areas occur where the potentiometric surface of the shallow aquifer is above the openings in the shale and the casing tops and allows discharge of contaminated ground water [fig. $12(\mathrm{~A})]$.

The most visible effects of abandoned lead and zinc mines on hydrogeology of the shallow aquifer are in the western area where artificialrecharge and discharge areas were created by mining. During active mining, water levels in the shallow aquifer were pumped below the level of the mine workings. Pumping created unconfined conditions, as indicated by water levels in the shallow aquifer in the Picher Field, which were 100 feet or more below the base of the confining shale, based on altitudes of the lower mine workings. When the last mine closed in 1970, water was no longer pumped to keep the mines dewatered, and water levels in the shallow aquifer rose to the base of the confining shale layer. Direct entry of surface water into the shallow aquifer through mining-related discontinuities and perforations of the confining shale accelerated recovery of water levels in the shallow aquifer, as indicated by a 120-foot rise in

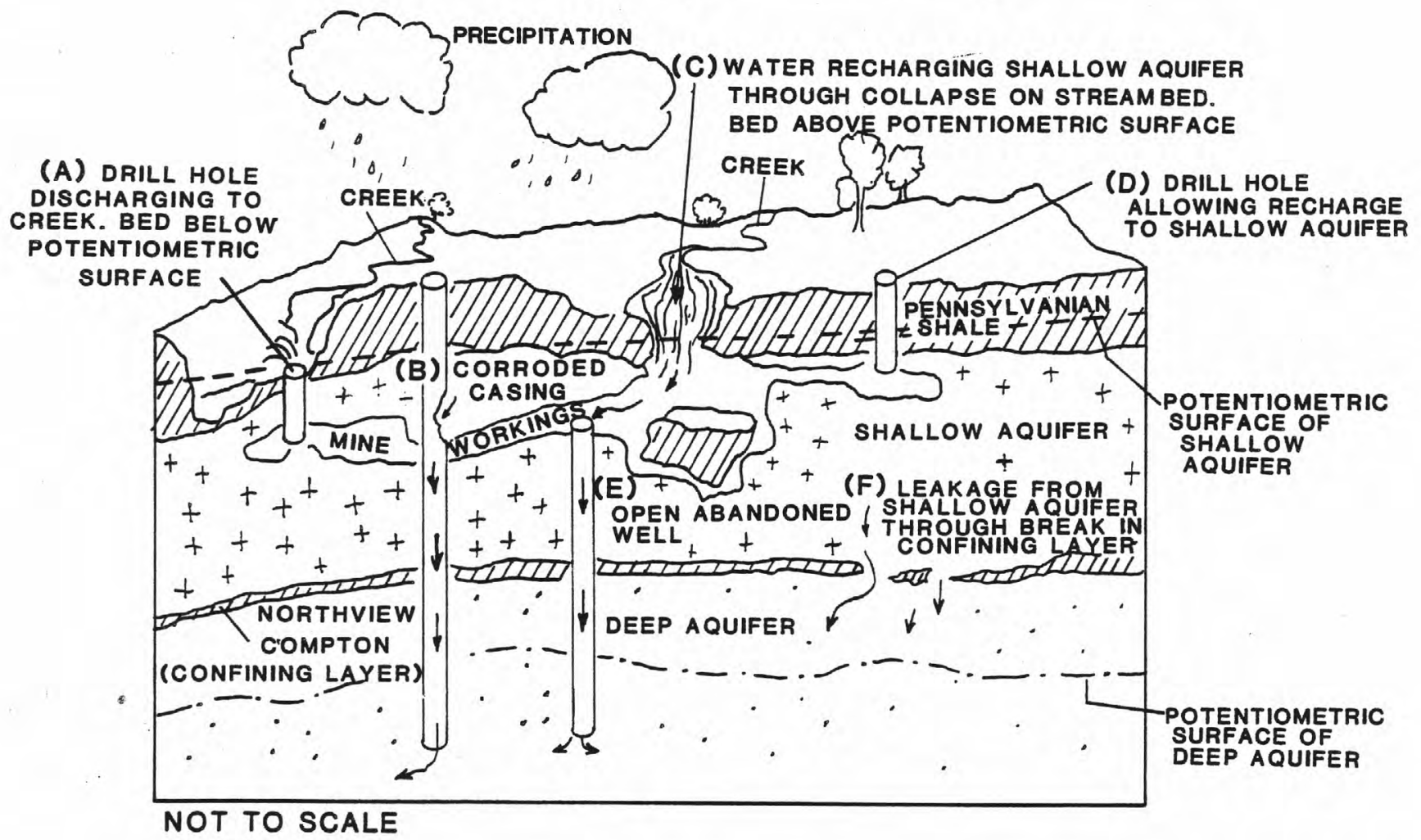

Figure 12.--Effects of abandoned lead-zinc mines on ground-water hydraulics in western area. 
water levels in the Lucky Jew Mine (mine 2, fig. 3) between 1976 and 1981. Direct entry of surface water into the shallow aquifer also has caused the ground-water mound northwest of Quapaw, Oklahoma (fig. 9).

Further evidence that significant localized recharge occurs through collapses, drill holes, and wells is indicated by the presence of localized ground-water mounds, which form during wet periods as shown in potentiometric maps published by Hittmann Associates (1981). Discharge of minecontaminated ground water from drill holes located south of Picher, Oklahoma, to Tar Creek began in 1979 when the potentiometric surface rose above the land surface and drill-hole casings (Hittmann Associates, 1981). These drill holes discharge as long as the potentiometric surface is above the land surface (approximately 800 feet). Discharges from these drill holes increase rapidly after periods of heavy rainfall (Ronald Jarman, Oklahoma Water Resources Board, oral commun., 1983), further indicating significant local recharge.

In the western area in Kansas, drill holes or well casings that discharged water continuously were not observed in the Tar Creek or Willow Creek basins at the time this study was conducted (April 1981 - March 1982), although some land owners in both basins reported short-term discharges from drill holes after heavy rainfall. It is possible that discharges from drill holes could occur in the future either in the Willow Creek basin or in a small unnamed creek basin (not shown) in the vicinity of Baxter Springs, Kansas, if the 800-foot potentiometric contour (fig. 9) shifts to the west. However, it is unlikely that continuous discharges will occur in the Tar Creek basin in Kansas because land-surface altitudes are generally above 820 feet. This is because the potentiometric surface of the shallow aquifer in OKlahoma and in a small part of the eastern part of the Picher Field in Kansas appears to have stabilized at approximately 800 feet, although during heavy rains it may rise above this altitude. The potentiometric surface may rise, however, if the discharging drill holes in $0 \mathrm{kl}$ ahoma are plugged without reducing local recharge.

A major effect of past-mining activities on the deep aquifer has been the lowering of the potentiometric surface below that of the shallow aquifer. This decline has been attributed to heavy pumpage resulting from increased demand by a growing population attracted to the area by the mining industry, as well as water demands of the industry itself (Stramel, 1957; MacFarlane and others, 1981). Even after mining stopped, towns and industries that remained in the area have maintained the large water demand. Stramel (1957) showed a historical decline in water levels in the deep aquifer, and Reed and others (1955) noted a decline of more than 400 feet between 1905 and 1947. Current (1983) water levels are more than 450 feet bel ow the 1905 levels at Miami, Oklahoma.

Lowering the potentiometric surface of the deep aquifer has created conditions favorable for downward movement of water from the shallow aquifer. Because of this, a potential problem that is of concern is the possible movement of water from mines in the shallow aquifer to the deep aquifer through "windows" in confining layers separating the shallow and deep aquifers [fig. 12(F)] or through deep, open drill holes or abandoned wells [fig. 12(B) and (E)]. Although several workers, as cited previously, have hypothesized that hydraulic connection between the shallow and deep aquifers is likely, no definitive data are available to confirm this. 
A gross estimate of possible downward-leakage volumes was calculated using reasonable hydraulic-conductivities values from similar lithologic units reported in published literature. Application of Walton's (1970) formula using an estimate of vertical hydraulic conductivity of $5 \times 10^{-5}$ $(\mathrm{gal} / \mathrm{d}) / \mathrm{ft}^{2}\left(7 \times 10^{-11} \mathrm{ft} / \mathrm{s}\right)$ given by Walton (1960) for the Maquoketa Shale in Illinois, which is assumed to be lithologically similar to the Northview Shale, yields an estimated annual leakage of approximately 3 billion gallons over the entire 735 square-mile area. The method of downward-leakage computation is described in the "Supplemental Information" section at the end of this report.

There is qualitative evidence, however, which suggests that leakage from the shallow aquifer is not regionally an important source of recharge to the deep aquifer. First, comparison of the potentiometric surface of ths shallow aquifer (fig. 9) with the deep aquifer (fig. 10) suggests that leakage from the shallow to the deep aquifer is small because there are no apparent cones of depression in the shallow aquifer coincident with those in the deep aquifer. If the two aquifers were hydraulically connected, effects of pumping in the deep aquifer should be visible in the shallow aquifer. Figure 9, in fact, shows a mound in the shallow aquifer where a cone should be if the two aquifer systems were hydraulically connected. Second, water-level data from an observation well in Miami, Oklahoma, presented by Marcher and others (1983) indicate that water levels declined between 1910 and 1973 and remained relatively constant until 1980. Water levels at the observation well have continued to decline since 1980 (Al MacFarlane, Kansas Geological Survey, oral commun., 1984). The observation well at Miami (not shown) is located approximately 3 miles south of Commerce, Oklahoma, and is in the area where the downward-leakage potential is greatest (see figure 11). Thus, even though water levels in the shallow aquifer rose rapidly since 1970, when the mines ceased operation, no corresponding rise has been observed in the well at Miami, Oklahoma. Continued water-level declines at this well suggest that leakage from the shallow aquifer is not significant. Third, a gamma log from a well at Galena, Kansas (fig. 13) suggests that the interval between 500 and 740 feet (the Cotter and Jefferson City Dolomites) contains low permeability, shaly rocks, as indicated by the high gamma activity. The low permeability rocks in the Cotter and Jefferson City Dolomites could retard downward movement of water and substantially reduce leakage.

Open drill holes or abandoned wells in the area potentially present the greatest contamination hazard to water supplies from the deep aquifer. Fifty-two deep wells were located in 0klahoma in mining areas (Oklahoma Water Resources Board, written commun., Tar Creek Briefing Document, April 5, 1983). Seven deep wells, formerly used for milling supplies, and four deep drill holes were located on maps of mine areas in Kansas. Several more abandoned, deep public-supply or former mine wells may exist in the area.

The following example illustrates the potential for downward movement of contaminated water from brecciated or mined zones of the shallow aquifer to the deep aquifer through drill holes open to both aquifers in the western area. A finite-difference radial-flow model of a well completed in two aquifers without leakage was developed by D. G. Jorgensen of the U.S. Geological Survey and was utilized to compute a hypothetical annual downward discharge. 


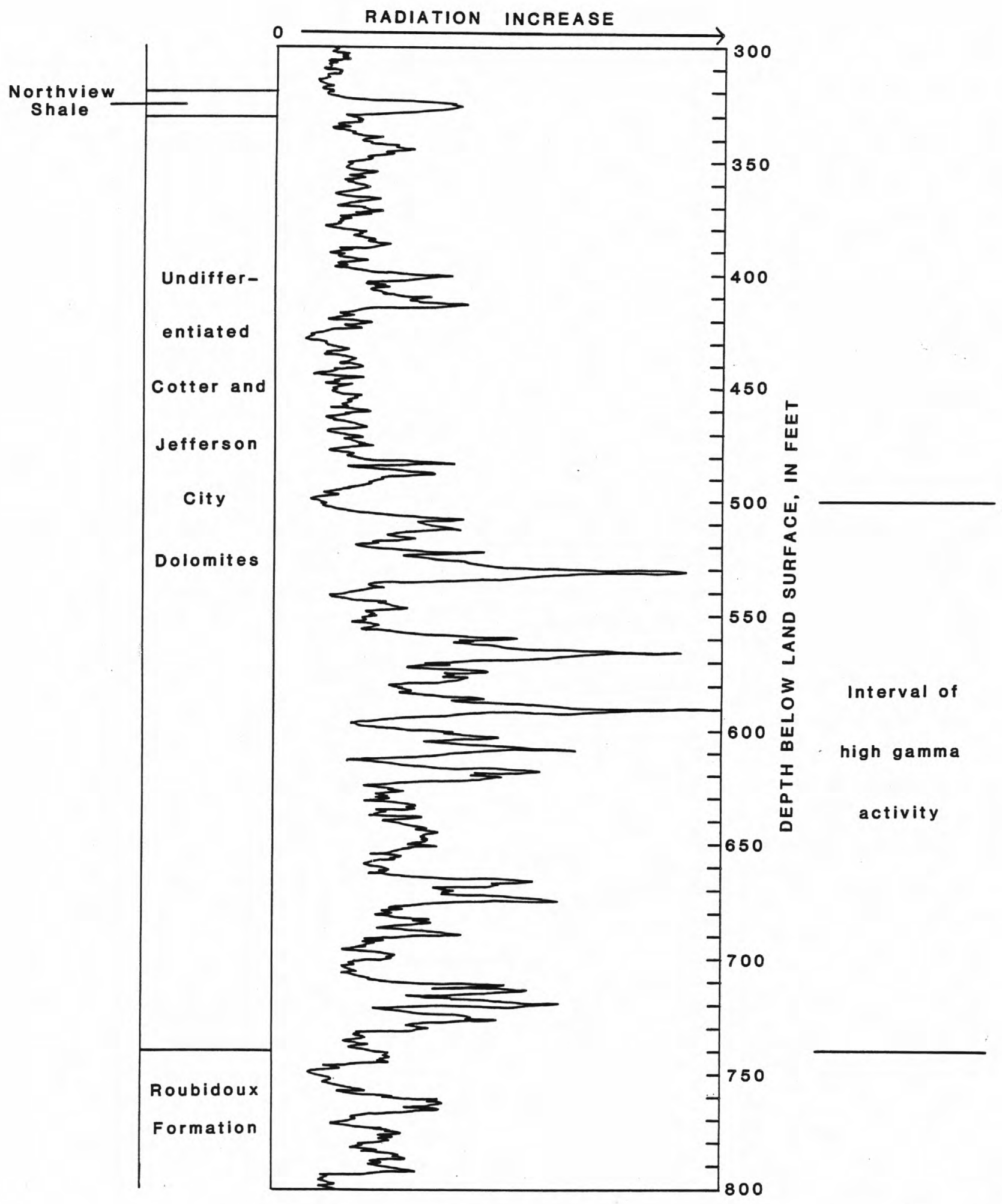

Figure 13.--Gamma log from well at Galena, Kansas. Log is shown for interval between 300 and 800 feet below land surface. 
The volume of water that may be moved through a 7-inch casing (the standard diameter for production wells in the area) is shown in table 5 for areas having a 50-foot and a 450-foot hydraulic-head difference between the shallow and deep aquifers. Typical hydraulic properties of the shallow and deep aquifers selected for the example were based on data shown in table 4. Although the potential is present for as much as 364 million gallons of water to move downward annually through a single well casing under the conditions assumed, there is no evidence currently (1983) available in Kansas that suggests deep drill holes are open and are not plugged. In addition, actual leakage would probably be orders of magnitude less than that hypothetically possible because of partially open casings and small holes restricting flow into and through the casing. However, there is great potential for movement of large volumes of undiluted water through drill holes into the deep aquifer in localized areas.

Table 5.--Hypothetical estimate of the volume of water that could discharge to the deep aquifer through an open, 7-inch well casing for a 50-foot and a 450-foot difference in hydraulic heads between the shallow and deep aquifers

[A nonleaky aquifer is assumed]

\begin{tabular}{|c|c|c|c|c|c|}
\hline \multirow[t]{2}{*}{$\begin{array}{c}\text { Hydraulic- } \\
\text { head difference } \\
\text { (feet) }\end{array}$} & \multicolumn{2}{|c|}{$\begin{array}{l}\text { Assumed } \\
\text { transmissivity } \\
\text { (feet squared } \\
\text { per day) }\end{array}$} & \multicolumn{2}{|c|}{$\begin{array}{l}\text { Assumed } \\
\text { storage coefficient } \\
\text { (dimensionless) }\end{array}$} & \multirow[t]{2}{*}{$\begin{array}{c}\text { Estimated } \\
\text { discharge } \\
\text { (gallons per year) }\end{array}$} \\
\hline & $\begin{array}{l}\text { Shallow } \\
\text { aquifer }\end{array}$ & $\begin{array}{l}\text { Deep } \\
\text { aquifer }\end{array}$ & $\begin{array}{l}\text { Shall ow } \\
\text { aquifer }\end{array}$ & $\begin{array}{l}\text { Deep } \\
\text { aquifer }\end{array}$ & \\
\hline 50 & 1,000 & 1,400 & 0.0003 & 0.0009 & $40,000,000$ \\
\hline 450 & 1,000 & 1,400 & .0003 & .0009 & $364,000,000$ \\
\hline
\end{tabular}

\section{Surface Water}

Regional Characteristics

Flow characteristics of streams that drain the Pennsylvanian shales in the western area differ significantly from flow characteristics of streams draining Mississippian limestones east of the Spring River. These differences are illustrated in figure 14.

Lightning Creek near McCune, Kansas (drainage area, 197 square miles), which is located approximately 6 miles west of the study area, is probably representative of most streams draining the Pennsylvanian shales. Streams draining the shales are typically ephemeral; for almost 50 percent of the year, flows from Lightning Creek near McCune are less than $0.05\left(\mathrm{ft}^{3} / \mathrm{s}\right) \mathrm{mi}^{2}$. 


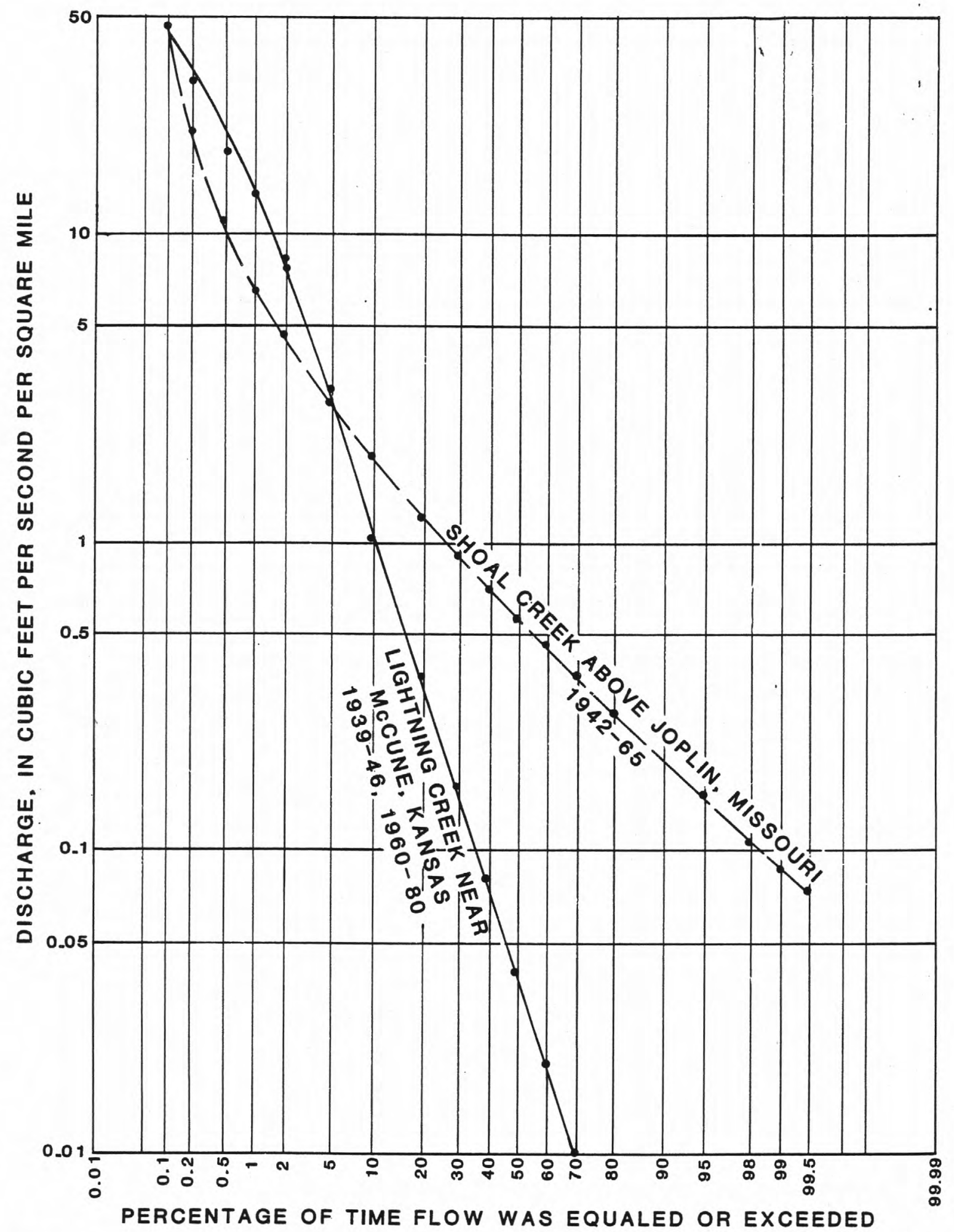

Figure 14.--Flow-duration curves of streams draining Pennsylvanian-age shales (Lightning Creek) and Mississippian-age limestones (Shoal Creek).

Figure 14 indicates that the relatively impervious Pennsylvanian rocks contribute very little base flow. During July and August of 1981, when seepage investigations were conducted in the area, most of the streams were dry, with exception of the downstream part of Tar Creek near the 
Kansas-0klahoma State line and Willow Creek near Baxter Springs, Kansas.

Streams in the eastern area are typically perennial, with base flows sustained by discharge of ground water from the limestones. A typical stream east of the Spring River, Shoal Creek above Joplin, Missouri (drainage area, 410 square miles), exhibited signifjcant base flow; flow at this location never declined below $0.07\left(\mathrm{ft}^{3} / \mathrm{s}\right) / \mathrm{mi}^{2}$, and 98 percent of the time flows exceeded $0.1\left(\mathrm{ft}^{3} / \mathrm{s}\right) / \mathrm{mi}^{2}$. Figure 14 indicates that this stream exhibits lower flows during periods of runoff compared to Lightning Creek and suggests that generally a greater proportion of rainfall in this basin infiltrates into the soil and rocks.

\section{Effects of Abandoned Mines on Streamflow}

The effects of abandoned lead and zinc mines on surface-water hydrology in the study area are difficult to assess quantitatively because very little long-term data from comparable stations in mined and unmined areas are available. Therefore, evaluation of effects of the abandoned mines on surface-water hydrology is necessarily qualitative and is based on general hydrologic principles and on observations by the author.

One of the major general effects on surface-water hydrology associated with the mines is increased base flows due to increased ground-water storage either in the fractured porous material in the chat on the land surface or in voids in the mines, or both. In the eastern area in the Short Creek valley near Galena, Kansas, where ground water discharges from the breccia to the stream, voids created by mining and pervious chat on the land surface probably have caused increased base flows. In the western area in Kansas, ore deposits were mined more than 100 feet below the land surface. The mines, therefore, were developed below impervious Pennsylvanian shales confining the shallow aquifer. These shales, as indicated in the previous section, naturally provide little or no base flow to streams in the western area. Chat, or mine tailings, however, were placed on the land surface in vast quantities and thus provide a porous medium for storage and recharge derived from precipitation. These chat piles act as perched aquifer systems on the impervious shales, slowly drain for several days or weeks, and provide a source of base flows to streams that was not present before mining took place. Seven hundred and forty-seven acres (McCauley and others, 1983, p. 34) or more than 10 percent of the Tar Creek basin in Kansas is covered with chat.

Qualitative evidence that chat piles significantly affect the surfacewater hydrology by increasing base flow is derived from the observation by the author during August 1981, that Tar Creek in the vicinity of the extensive chat piles near Treece, Kansas, and Willow Creek downstream from the mined areas were the only streams in the western area in Kansas that were flowing. Neither Tar Creek nor Willow Creek were flowing upstream from the mined areas. Brush Creek and Shawnee Creek to the north (fig. 4) did not flow during August 1981. 
Another observable effect of past-mining activities on surface-water hydrology in the western area is physical alteration of the stream channel and reduction of water moving in the stream channel. This has occurred in the Tar Creek basin in Kansas where the stream channel subsided due to collapse of a mine room and where the potentiometric surface of the shallow aquifer is below the altitude of the stream channel. Consequently, surface water drains directly into a collapse located in T. 34 S., R. 23 E., sec. 2 from approximately 4.5 square miles upstream from the collapse (fig. 9). Collapses, drill holes, and shafts on the flood plain or streambed intercept water in the stream and reduce the amount of water moving in the stream channel downstream from the points of interception. This situation is shown schematically in figure 12 (C). Interception of water in the channel by breaches in the shales would tend to substantially reduce flood flows.

Surface-water hydrology in the western area also may be affected by discharge of ground water in the shallow aquifer from abandoned drill holes to surface streams (fig. 13) where the potentiometric surface of the shallow aquifer is above the altitude of the stream channel. Such discharges increase base flow of surface streams. As noted al ready, this problem has been observed in Tar Creek in Oklahoma (fig. 9) but was not observed in Kansas.

\section{QUALITY OF WATER}

\section{Ground Water}

Shallow Aquifer

Chemical-quality characteristics of water from wells in the shallow aquifer in Kansas are shown in table 6. Water from wells in the shallow aquifer generally met Federal drinking-water standards (table 7), although some wells (wells 111, 115-117, table 20 near the end of this report) contained concentrations of iron, manganese, and sulfate that were larger than the suggested maximum concentration.

In the eastern area, water from most wells located north of Shoal Creek produced calcium bicarbonate sulfate or calcium sulfate type water, with largest concentrations of dissolved chemical constituents occurring near the Pennsylvanian-Mississippian contact (fig. 15). The largest concentrations of dissolved iron, sulfate, and zinc occurred in water from wells 111, 115-117 (fig. 3 and table 20 near the end of this report). These large concentrations may be due either to local dissolution of sulfide deposits (well 117 is not located downgradient from any known mined area) or to movement of mineralized water from upgradient mines or mineralized zones.

Water samples from wells south of Shoal Creek in the eastern area did not appear to be affected by water from mined or mineralized zones. Few mines (see fig. 1) or brecciated areas (which are associated with mineralization, see fig. 7) are located south of Shoal Creek. Water from wells in this area (wells 112, 114, 136, 137, and 138, fig. 3) was a calcium bicarbonate type (fig. 15), and wells 112-114 (table 20) contained concentrations of trace metals, with the exception of zinc, of 1 ess than $20 \mu \mathrm{g} / \mathrm{L}$ (micrograms per liter). 
Table 6.--Summary of water-quality data for wells in the shallow aquifer

[Values are given in milligrams per liter $(\mathrm{mg} / \mathrm{L})$ or micrograms per liter $(\mu \mathrm{g} / \mathrm{L})$, except as noted]

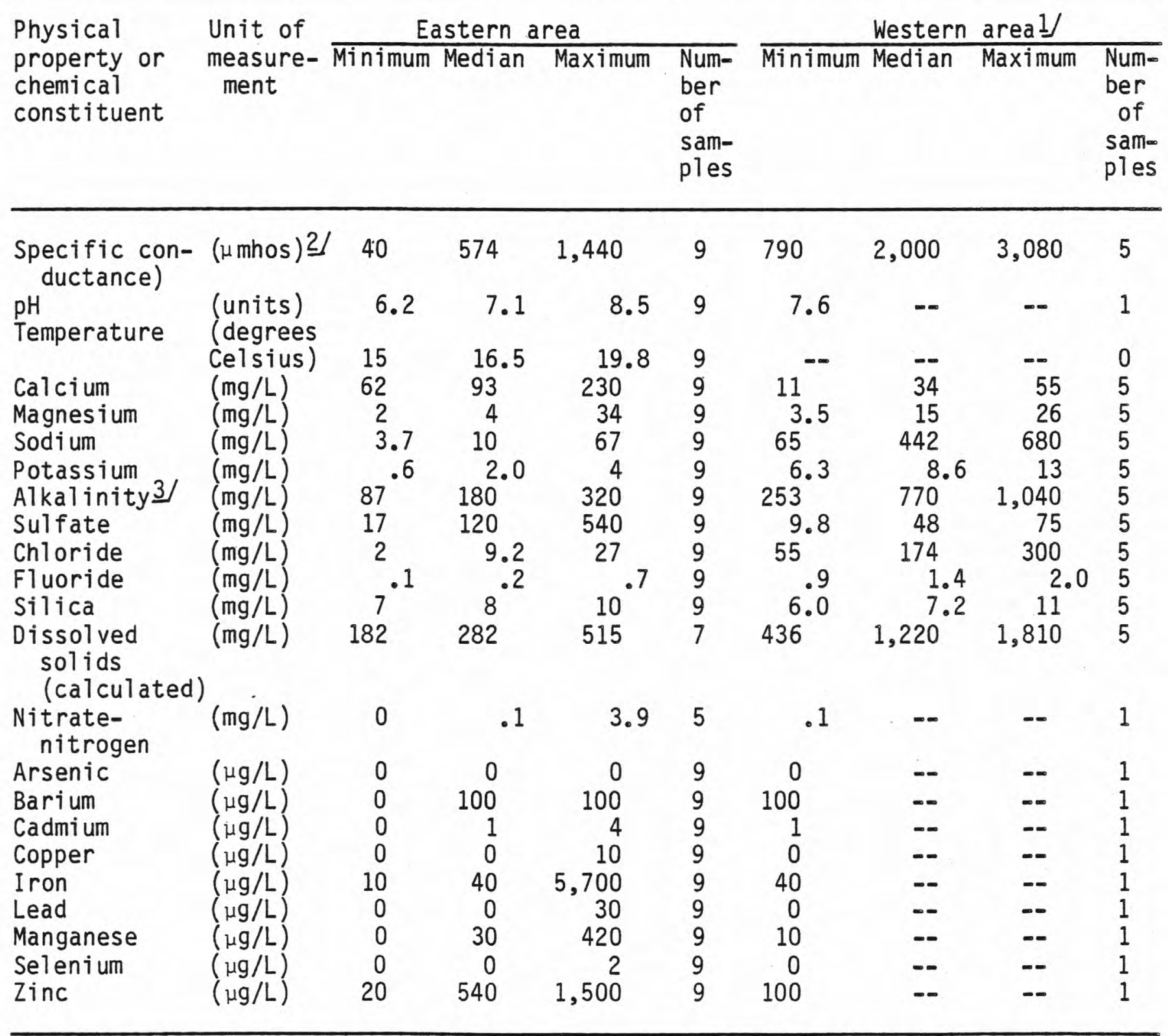

1 Data from four of the five wells were collected before this investigation.

2 Micromhos per centimeter at $25^{\circ}$ Celsius.

3 Alkalinity may be converted to bicarbonate by dividing by 0.82 . 
Table 7.--Selected chemical constituents and physical properties of water for wells in the shallow aquifer with percentages of observed values exceeding maximum contaminant concentrations established by the U.S. Environmental Protection Agency (1976b; 1977).

\begin{tabular}{|c|c|c|c|c|c|}
\hline $\begin{array}{l}\text { Chemical } \\
\text { constituent } \\
\text { or physical } \\
\text { property }\end{array}$ & $\begin{array}{l}\text { Unit } \\
\text { of } \\
\text { measure- } \\
\text { ment }\end{array}$ & $\begin{array}{l}\text { Maximum contaminant } \\
\text { concentration or } \\
\text { recommended } \\
\text { maximum } \\
\text { concentration }\end{array}$ & $\begin{array}{l}\text { Percentage } \\
\text { of samples } \\
\text { exceeding } \\
\text { maximum con- } \\
\text { taminant con- } \\
\text { centration }\end{array}$ & $\begin{array}{l}\text { Ratio of } \\
\text { maximum } \\
\text { observed } \\
\text { concentra- } \\
\text { tion to } \\
\text { maximum } \\
\text { contaminant } \\
\text { concentration }\end{array}$ & $\begin{array}{l}\text { Number } \\
\text { of } \\
\text { samples }\end{array}$ \\
\hline Arsenic & $(\mu \mathrm{g} / \mathrm{L}) \underline{1}$ & 50 & 0 & 0 & 10 \\
\hline Barium & $(\mu \mathrm{g} / \mathrm{L})$ & 1,000 & 0 & 0.1 & 10 \\
\hline Cadmi um & $(\mu \mathrm{g} / \mathrm{L})$ & 10 & 0 & .4 & 10 \\
\hline Iron & $(\mu \mathrm{g} / \mathrm{L})$ & $2 / 300$ & 22 & 19 & 10 \\
\hline Lead & $(\mu \mathrm{g} / \mathrm{L})$ & 50 & 0 & .4 & 10 \\
\hline Manganese & $(\mu \mathrm{g} / \mathrm{L})$ & $2 / 50$ & 22 & 8.4 & 10 \\
\hline $\mathrm{pH}$ & (units) & $2 / 6.5-8.5$ & 0 & - & 10 \\
\hline Sulfate & $(\mathrm{mg} / \mathrm{L})^{3 /}$ & $2 / 250$ & 7 & 2.2 & 14 \\
\hline Zinc & $(\mu \mathrm{g} / \mathrm{L})$ & $2 / 5,000$ & 0 & .3 & 10 \\
\hline
\end{tabular}

1 Micrograms per liter.

2 Recommended maximum or range based on aesthetic reasons only (that is, taste or color).

3 Milligrams per liter.

Water from mines in the eastern area contained relatively small dissolvedsolids concentrations (generally less than $500 \mathrm{mg} / \mathrm{L}$ ), $1 \mathrm{ow} \mathrm{pH}(3.6-6.5)$, and generally very large concentrations of zinc, cadmium, lead, and manganese (table 8). Large iron concentrations were observed in water analyses from the lower levels of two mines (analyses from mines 24 and 31 , see table 21 at the end of this report), but the median concentration from all mines sampled was only $70 \mathrm{\mu g} / \mathrm{L}$, indicating generally small concentrations of iron in mines in the eastern area. Zinc, cadmium, and lead occur at concentrations many times greater than suggested by Federal aquatic and mandatory, primary drinking-water 


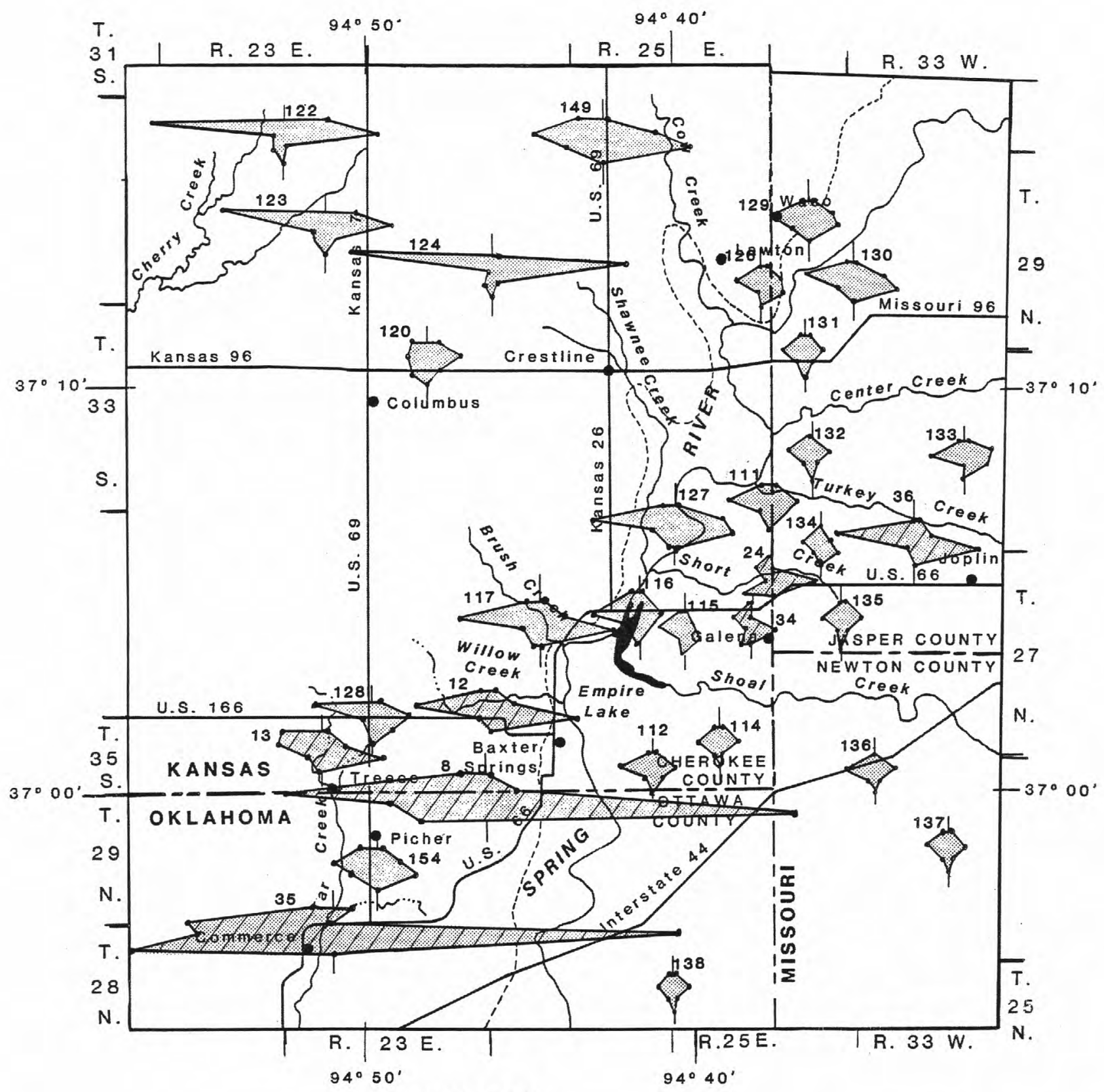

EXPLANATION

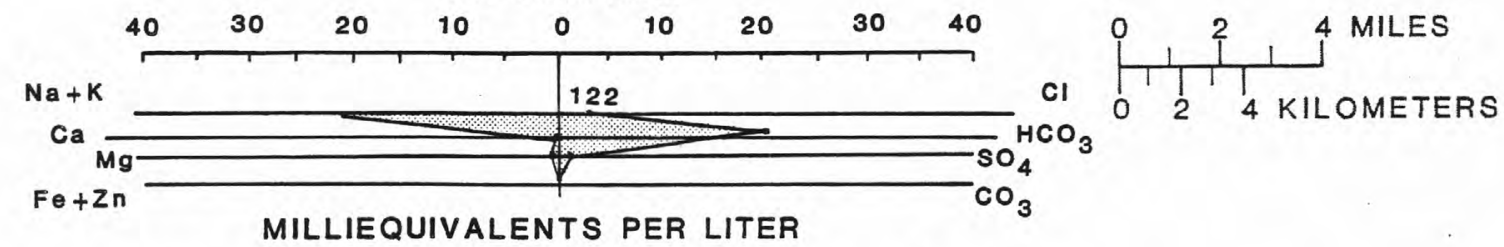

Number at top of diagram refers to map number shown

in figure 3. Diagonal lines indicate water is from a mine

----APPROXIMATE LOCATION OF GEOLOGIC CONTACT BETWEEN

PENNSYLVANIAN AND MISSISSIPPIAN ROCKS

Figure 15.--Chemical-quality characteristics of water from selected wells and mines in shallow aquifer. 
Table 8.--Summary of water-quality data for mines in the shallow aquifer

[Values are given in milligrams per liter $(\mathrm{mg} / \mathrm{L})$ or micrograms per liter $(\mu \mathrm{g} / \mathrm{L})$, except as noted]

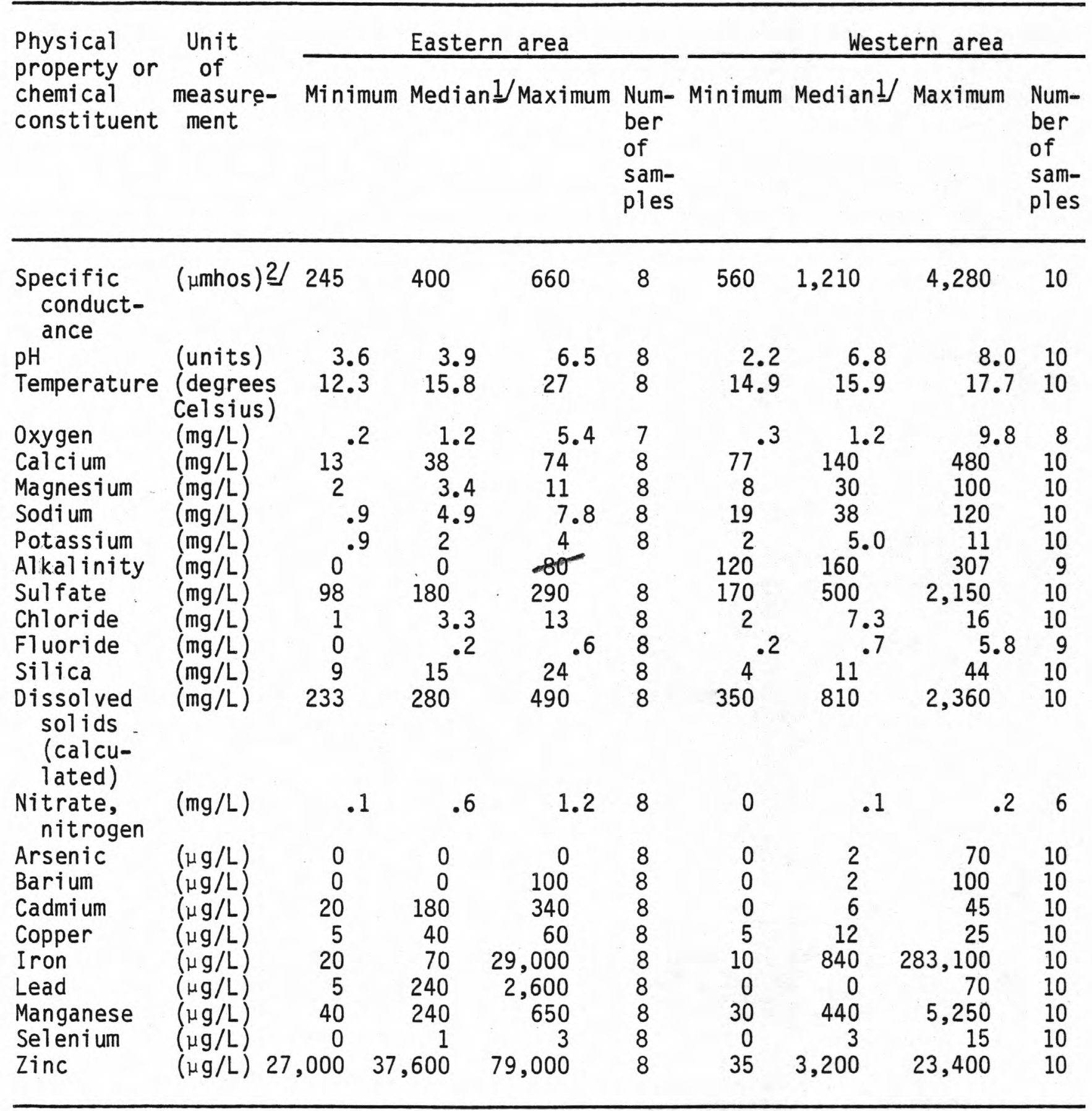

1 Sampling-site medians were computed before areal medians.

2 Micromhos per centimeter at $25^{\circ}$ Celsius. 
standards for these constituents (see U.S. Environmental Protection Agency, $1976 \mathrm{a} ; 1976 \mathrm{~b})$. Water from eastern-area mines is generally a calcium sulfate or calcium zinc sulfate type water (fig. 15, mines 24, 34, and 36). Because mines in this area occur in brecciated areas where the lithology is primarily siliceous chert and is essentially devoid of limestone [calcium carbonate $\left(\mathrm{CaCO}_{3}\right)$ ] (Haworth, 1904, p. 112), these waters have very little buffering capacity and very small concentrations of the bicarbonate ion $\left(\mathrm{HCO}_{3}{ }^{-}\right)$. Any available bicarbonate is consumed by the acidity of waters in the mines.

Water from wells in the shallow aquifer generally is characterized as a sodium bicarbonate or calcium sodium bicarbonate chloride type water near the western edge of the study area (fig. 15, wells 120, 122, 123, and 124, tables 20 and 24 near the end of this report). A water sample obtained from a well in the western area (well 120, table 20 at the end of this report) near Columbus, Kansas, exhibited small concentrations of iron, manganese, cadmium, and zinc. Sulfate reduction in the presence of anaerobic microbes was suggested by the presence of a strong hydrogensulfide $\left(\mathrm{H}_{2} \mathrm{~S}\right)$ odor from this well. Water from other wells in the area also contains hydrogen sulfide. Few wells in the shallow aquifer in the western area are used because of the presence of hydrogen sulfide.

Water from mines in the western area ranged in dissolved-solids concentrations from 350 to $2,360 \mathrm{mg} / \mathrm{L}$, with a $\mathrm{pH}$ of between 2.2 and 8.0 , and contained large median concentrations of calcium, iron, manganese, zinc, and sulfate (table 8). Water in the mines ranged from a calcium sodium sulfate bicarbonate type (mine 13, fig. 15) to a calcium magnesium iron sulfate type (mine 8, fig. 15).

\section{Deep Aquifer}

Water from the deep aquifer in the eastern area is characterized by dissolved-solids concentrations of generally less than $500 \mathrm{mg} / \mathrm{L}$, small concentrations of trace metals, and a calcium bicarbonate or calcium magnesium bicarbonate type water adequate for most uses (fig. 16 and tables 9 and 10). Water from the deep aquifer in the western area is characterized by dissolved-solids concentrations of between 167 and $1,030 \mathrm{mg} / \mathrm{L}$ and generally small concentrations of trace metals, although wells 217,219 , and 220 (table 22 near the end of this report) contained iron concentrations of more than $300 \mathrm{\mu g} / \mathrm{L}$. Calcium bicarbonate or calcium bicarbonate sulfate type water was obtained from wells at Baxter Springs and Treece, Kansas, (well 225, not shown, and well 221, fig. 16) and at Commerce and Picher, Oklahoma (wells 217, 218, fig. 16). Well 220 at Baxter Springs produced calcium sulfate type water (fig. 16). Sodium chloride or sodium bicarbonate type water was produced from wells north and west of a line between Baxter Springs and Crestline, Kansas (wells 211-213, 216, and 219, fig. 16). Hydrogen sulfide $\left(\mathrm{H}_{2} \mathrm{~S}\right)$ is associated with many wells in the western area. The area where $\mathrm{H}_{2} \mathrm{~S}$ is produced was referred to as the "transition zone" by MacFarlane and others (1981). They also reported that water in the deep aquifer west of the "transition zone" is a sodium chloride type. MacFarlane and others (1981) attributed the occurrence of sodium and bicarbonate in the deep aquifer to contributions from the overlying shallow aquifer as a result of wells that are open between the two aquifer systems. Water-quality variations in different formations in the deep aquifer and lack of segregation of formation waters also may be responsible for highly variable water-quality characteristics observed in the western area. 


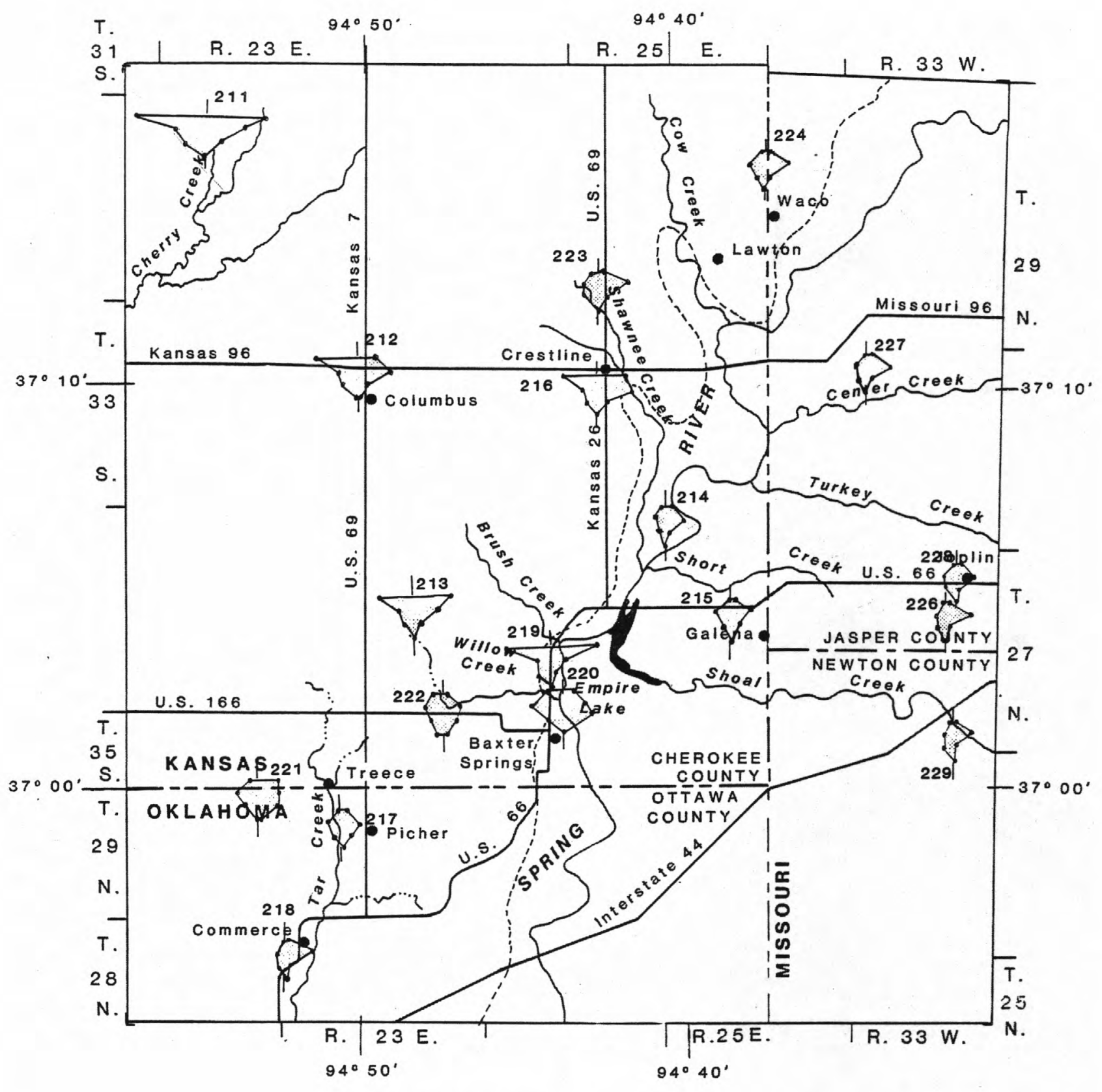

EXPLANATION
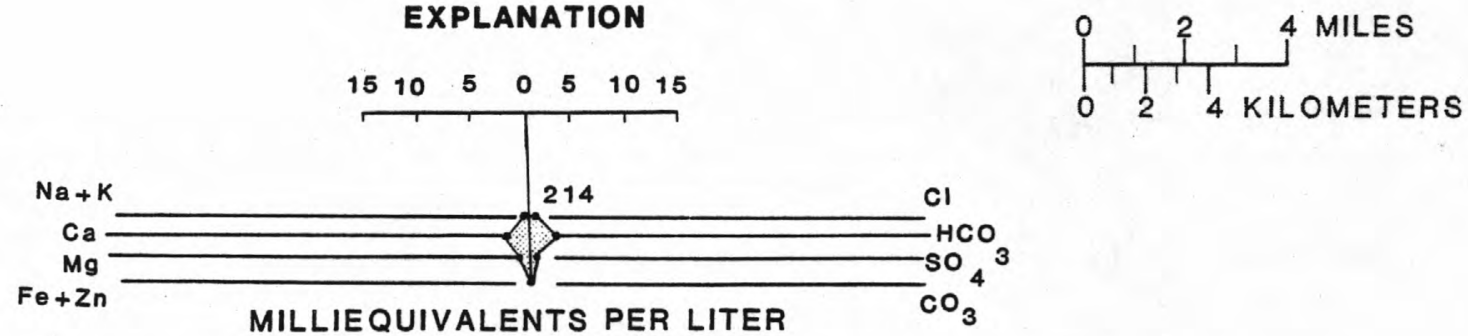

Number at top of diagram refers to map number shown in figure 3

APPROXIMATE LOCATION OF GEOLOGIC CONTACT BETWEEN PENNSYLVANIAN AND MISSISSIPPIAN ROCKS

Figure 16.--Chemical-quality characteristics of water from selected wells in deep aquifer. 
Table 9.--Summary of water-quality data for wells in the deep aquifer [Values given in milligrams per liter $(\mathrm{mg} / \mathrm{L})$ or micrograms per liter $(\mu \mathrm{g} / \mathrm{L})$, except as noted]

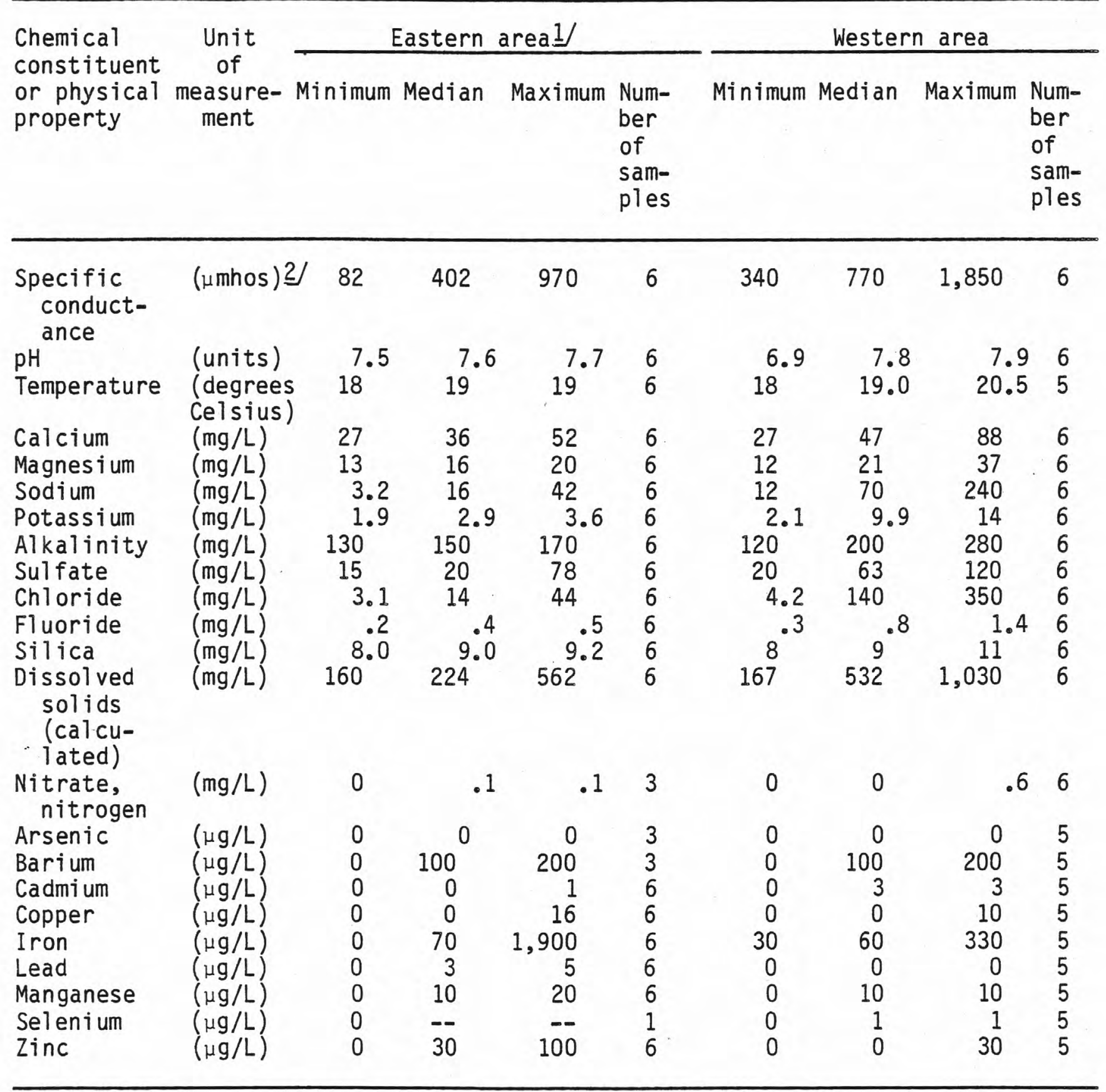

1 Three wells were sampled at Baxter Springs, Kansas. Median concentrations for these constituents were computed for these three wells and utilized as one observation for the areal summary.

2 Micromhos per centimeter at $25^{\circ}$ Celsius. 
Table 10.--Selected chemical constituents and physical properties of water for wells in the deep aquifer with percentages of observed values exceeding maximum contaminant concentrations established by the U.S. Environmental Protection Agency (1976b; 1977)

\begin{tabular}{|c|c|c|c|c|c|}
\hline $\begin{array}{l}\text { Chemical } \\
\text { constituent }\end{array}$ & $\begin{array}{c}\text { Unit } \\
\text { of }\end{array}$ & $\begin{array}{c}\text { Maximum } \\
\text { contaminant }\end{array}$ & $\begin{array}{l}\text { Percentage } \\
\text { of samples }\end{array}$ & $\begin{array}{l}\text { Ratio of } \\
\text { maximum ob- }\end{array}$ & $\begin{array}{c}\text { Number } \\
\text { of }\end{array}$ \\
\hline $\begin{array}{l}\text { or } \\
\text { physical } \\
\text { property }\end{array}$ & $\begin{array}{c}\text { measure- } \\
\text { ment }\end{array}$ & $\begin{array}{l}\text { concentration } \\
\text { or recommended } \\
\text { maximum con- } \\
\text { centration }\end{array}$ & $\begin{array}{l}\text { exceeding } \\
\text { maximum } \\
\text { contaminant } \\
\text { concentration }\end{array}$ & $\begin{array}{l}\text { served con- } \\
\text { centration to } \\
\text { maximum con- } \\
\text { taminant con- } \\
\text { centration }\end{array}$ & samples \\
\hline
\end{tabular}

\begin{tabular}{llcccc}
\hline Arsenic & $(\mu \mathrm{g} / \mathrm{L}) 1 /$ & 50 & 0 & 0 & 9 \\
Barium & $(\mu \mathrm{g} / \mathrm{L})$ & 1,000 & 0 & .20 & 9 \\
Cadmi um & $(\mu \mathrm{g} / \mathrm{L})$ & $2 / 30$ & 0 & .30 & 9 \\
Iron & $(\mu \mathrm{g} / \mathrm{L})$ & $2 / 300$ & 22 & 6.3 & 9 \\
Lead & $(\mu \mathrm{g} / \mathrm{L})$ & 50 & 0 & .10 & 9 \\
Manganese & $(\mu \mathrm{g} / \mathrm{L})$ & $2 / 50$ & 0 & .40 & 9 \\
pH & $(\mathrm{units})$ & $2 / 6.5-8.5$ & 0 & --.49 & 9 \\
Sulfate & $(\mathrm{mg} / \mathrm{L}) 3$ & $2 / 250$ & 0 & .02 & 9 \\
Zinc & $(\mu \mathrm{g} / \mathrm{L})$ & $2 / 5,000$ & 0 & .02 & \\
\hline
\end{tabular}

1 Micrograms per liter at $25^{\circ}$ Celsius.

2 Recommended maximum or range based on aesthetic reasons only (that is, taste or color).

3 Milligrams per liter.

\section{Effects of Abandoned Mines on Water Quality}

Potential effects of abandoned lead-zinc mines on chemical quality of ground water are:

1. Local changes in ground-water chemical quality in mineralized zones that were mined,

2. migration of contaminated water laterally from the mines into areas of the shallow aquifer used for domestic and stock supplies, and

3. vertical migration of contaminated water from the mines towards the deep aquifer, which is used for public-water supplies.

Local changes in water quality in the mineralized areas cannot be evaluated statistically because very few water samples were obtained from wells in the mineralized areas before they were mined. However, an early report by Bailey (1911) for the eastern area indicates that water in the ore-bearing rocks were "devoid of zinc, iron, and calcium sulphate and... free sulphuric acid when the ore deposits [were] first opened." After 
mining began, both Bailey (1911) and Haworth (1904) reported that highly corrosive acid water formed in the mines. These authors reported that water quality was poorest from mines in which the water levels fluctuated due to periodic pumping. The poor water quality was attributed to cyclic oxidation-dissolution of the ore deposits.

Mining in the eastern area caused disturbance of the sulfide ores and exposed them to large quantities of oxygen, creating a geochemically oxidizing environment conducive to dissolution of sulfide minerals and generation of acidity. Although changes in analytical and sampling methods could account for observed differences in concentrations, comparison of median concentrations of calcium, iron, manganese, zinc, lead, and silica in water from 11 mines reported by Bailey (1911) (table 11) with water in the mines in 1981 (table 8) suggests a decrease in concentrations of trace metals and sulfate. 1/ The large concentrations of trace metals and sulfate present in the mine waters in the early 1900's probably were maintained due to continual disturbance of the ore deposits and constant introduction of oxygen and water to the mines. The following equation may explain the presence of large iron and sulfate concentrations observed during the period of active mining:

$$
\mathrm{FeS}_{2}+\frac{7}{2} \mathrm{O}_{2}+\mathrm{H}_{2} \mathrm{O} \longrightarrow \mathrm{Fe}^{2+}+2 \mathrm{SO}_{4}^{2-}+2 \mathrm{H}^{+} .
$$

After mining activities ceased in the Galena Field in the eastern area by the 1940's, pumpage to allow dewatering of the mines stopped, and water filled the mines. As the hydrologic system stabilized somewhat, the amount of soluble oxidation products [iron sulfate $\left(\mathrm{FeSO}_{4}\right)$ ] probably decreased because large quantities of sulfide minerals were no longer exposed to moist air or periodically saturated with water. Eventually, with less iron sulfide $\left(\mathrm{FeS}_{2}\right)$ being exposed and oxidized, the decrease in iron concentrations could be due to oxidation of ferrous iron $\left(\mathrm{Fe}^{2+}\right)$ to ferric iron $\left(\mathrm{Fe}^{3+}\right)$ and finally precipitation of iron hydroxide:

$$
\begin{aligned}
& \mathrm{Fe}^{2+}+\frac{1}{2} \mathrm{O}_{2}+\mathrm{H}^{+} \rightarrow \mathrm{Fe}^{3+}+\frac{1}{2} \mathrm{H}_{2} \mathrm{O} \\
& \mathrm{Fe}^{3+}+3 \mathrm{H}_{2} \mathrm{O} \rightarrow \mathrm{Fe}(\mathrm{OH})_{3} \text { (solid) }+3 \mathrm{H}^{+} .
\end{aligned}
$$

Geochemically oxidizing conditions have persisted in ground water in mines and breccia in the eastern area. Water from shafts sampled during 1981 indicated the presence of oxygen, even in the lower level mines. Largest concentrations of dissolved oxygen occurred in water from the upper

1/ Values given by Bailey (1911) are total concentrations, while those reported here (table 8) are dissolved. Although this should be kept in mind, the dissolved fractions of iron, manganese, zinc, and lead probably composed at least 75 percent of the reported concentrations based on recent analyses of mine waters (see Playton and others, 1978). Values for calcium, sulfate, and silica probably are comparable. 
Table 11.--Statistical summary of selected chemical constituents in water collected from mines and concentration mills near Galena, Kansas, during March and April 1905

[Data from Bailey (1911). Values given in milligrams per liter (mg/L) and in micrograms per liter $(\mu \mathrm{g} / \mathrm{L})]$

\begin{tabular}{|c|c|c|c|c|c|}
\hline $\begin{array}{l}\text { Chemical } \\
\text { constituent }\end{array}$ & $\begin{array}{c}\text { Unit } \\
\text { of } \\
\text { measure- } \\
\text { ment }\end{array}$ & Minimum & Median & Maximum & $\begin{array}{l}\text { Number } \\
\text { of } \\
\text { samples }\end{array}$ \\
\hline
\end{tabular}

\begin{tabular}{lrrrrr}
\hline Total calcium & $(\mathrm{mg} / \mathrm{L})$ & 136 & 280 & 457 & 11 \\
Total sulfate & $(\mathrm{mg} / \mathrm{L})$ & 307 & 3,028 & 5,500 & 11 \\
Total iron & $(\mu \mathrm{g} / \mathrm{L})$ & 1,800 & 237,000 & 855,000 & 11 \\
Total manganese & $(\mu \mathrm{g} / \mathrm{L})$ & 4,100 & 7,300 & 311,200 & 4 \\
Total zinc & $(\mu \mathrm{g} / \mathrm{L})$ & 678,000 & $1,238,000$ & $1,852,000$ & 11 \\
Total lead & $(\mu \mathrm{g} / \mathrm{L})$ & 5,700 & 21,350 & 37,000 & 2 \\
Total silica & $(\mathrm{mg} / \mathrm{L})$ & 18 & 58 & 1,850 & 11 \\
& & & & & \\
\hline
\end{tabular}

part of the mine shafts (table 21 at the end of this report), indicating an influx of oxygenated recharge from precipitation. Although sulfide deposits in the mined areas probably have been substantially oxidized, oxygenated recharge moving through large deposits of chat and rock, which contain sulfide minerals, and seasonal fluctuations in the water table, which allow wetting and drying of sulfide minerals near the water table, have caused continued oxidation of sulfide minerals, as indicated by the predominance of the sulfate ion and large concentrations of trace metals and low pH (table 8).

Mines in the eastern area during 1981 and 1982 contained "poor" quality water; water in these mines generally had a pH of below 5 and concentrations of zinc, cadmium, manganese, and, in some cases, lead that precluded use of this water for any purpose. Because these mines are located in siliceous chert with little limestone and apparently do not receive significant quantities of ground water from surrounding limestones, the mine waters are poorly buffered and will probably remain chemically similar to that observed for an indefinite period of time (until the exposed sulfide minerals are entirely oxidized).

Quantitative information was not found on pre-mining water quality in mineralized zones of the western area. Although from the chemical-quality information obtained for this study north of the Picher Field in Kansas, it appears that water in the shallow aquifer of the western area was probably a calcium bicarbonate sulfate or calcium sulfate type within the Picher Field. Water in the shallow aquifer at the western. edge of the mining district and west of the district is a calcium or sodium bicarbonate type, which is low in sulfate as shown by wells 120, 122-124, and 128 in figure 15. 
Water in the Kansas-0klahoma mining district probably was usable for most purposes but contained large concentrations of hydrogen sulfide $\left(\mathrm{H}_{2} \mathrm{~S}\right)$. McKnight and Fischer (1970, p. 145) reported that $\mathrm{H}_{2} \mathrm{~S}$ was conspicuous in many of the workings when they were first opened and that water pumped from the Garrett mine (mine 18, fig. 3) in early stages of dewatering reeked of $\mathrm{H}_{2} \mathrm{~S}$.

Mining caused degradation of ground-water quality in the vicinity of the mines. Conversations with area residents indicated that their wells went dry during the mid-1920's to 1930 's as a result of pumping the mines. However, after water levels partially recovered during the late 1940's, most residents apparently did not use water from the shallow aquifer. One resident reported that the water iron-stained plumbing fixtures and tasted bitter after the peak of the mining days. Maximum concentrations of sulfate, iron, manganese, zinc, cadmium, lead, selenium, and some other chemical constituents (table 8) indicate that water in the mines during 1981 was not usable for most purposes (based on information in tables 15-19 in Playton and others, 1978, and in-table 7 of this report).

During active mining of the Picher Field, the poorest water quality in Kansas was associated with mines near the eastern edge of the field. This was attributed by Kinney (1941) to the presence of pyrite and marcasite, which-were associated with the basal part of the Cherokee Group (Des Moinesian Series) in the upper part of mine workings near Baxter Springs. In fact, Kinney (1941) did not discuss mine waters near the Treece-Picher area because he reported that these waters contained "no objectionable impurities." He reported $\mathrm{pH}$ values ranging from 2.4 to 3.9 and total iron concentrations from $350 \mathrm{mg} / \mathrm{L}[350,000$ micrograms per liter $(\mu \mathrm{g} / \mathrm{L})$ ] to $2,715 \mathrm{mg} / \mathrm{L}\left(2.715 \times 10^{6} \mu \mathrm{g} / \mathrm{L}\right)$ in waters from mines near Baxter Springs, compared to water from mines near Treece and Picher that had $\mathrm{pH}$ values ranging from 6.2 to 8.0 and total iron concentrations from $0.120 \mathrm{mg} / \mathrm{L}(120 \mu \mathrm{g} / \mathrm{L})$ to $1.4 \mathrm{mg} / \mathrm{L}(1,400 \mu \mathrm{g} / \mathrm{L})$.

Utilizing data from the current study, table 12 shows that specific conductance and concentrations of silica, dissolved iron, zinc, lead, and cadmium were much larger, and the pH and alkalinity-to-sulfate ratio was smaller in mine waters nearest the Pennsylvanian-Mississippian contact (eastern part of the Picher Field near Baxter Springs) than in those mine waters sampled in the western part of the Picher Field near Treece, Kansas, away from the geologic contact. Data shown in table 12 suggest that there are more oxidized sulfide minerals present in the Baxter Springs area (supporting Kinney's hypothesis) or that there is a less abundant source of bicarbonate ions available to neutralize sulfuric acid produced by sulfide oxidation in the mines near Baxter Springs.

In the Picher Field, the poorer-quality water from mines near the Pennsylvanian-Mississippian geologic contact may result from the relative absence of limestone in these ore deposits combined with acid-producing pyritic shales in the Cherokee Group, as suggested by Kinney (1941). McKnight and Fischer (1970, p. 135) noted that extensive "sheet-ground" ore deposits are associated with the highly siliceous Grand Falls Chert Member of the Boone Formation southwest of Baxter Springs, Kansas, and south of Cardin, Oklahoma. Table 12 indicates a larger dissolved-silica content from mines at the eastern edge of the Picher Field compared to those at the western edge. 
Table 12.--Comparison of selected chemical constituents and physical properties of water for mines in eastern and western parts of the Picher Field, Cherokee County, Kansas

[Values given in milligrams per liter (mg/L) and micrograms per liter ( $\mu \mathrm{g} / \mathrm{L})$, except at noted]

\begin{tabular}{|c|c|c|c|c|c|c|c|c|c|}
\hline \multirow{2}{*}{$\begin{array}{l}\text { Chemical } \\
\text { constituent } \\
\text { or physical } \\
\text { property }\end{array}$} & \multirow{2}{*}{$\begin{array}{l}\text { Unit } \\
\text { of } \\
\text { measure- } \\
\text { ment }\end{array}$} & \multicolumn{4}{|c|}{$\begin{array}{l}\text { Western part } 1 / \\
\text { (near Treece) }\end{array}$} & \multicolumn{4}{|c|}{$\begin{array}{c}\text { Eastern part2/ } \\
\text { (near Baxter Springs) }\end{array}$} \\
\hline & & Minimum & Median & Maximum & $\begin{array}{l}\text { Num- } \\
\text { ber } \\
\text { of } \\
\text { sam- } \\
\text { ples }\end{array}$ & Minimum & Median & Maximum & $\begin{array}{l}\text { Num- } \\
\text { ber } \\
\text { of } \\
\text { sam- } \\
\text { ples }\end{array}$ \\
\hline $\begin{array}{l}\text { pH } \\
\text { Specific }\end{array}$ & (units) & 6.4 & 7 & 7.1 & 5 & 2.2 & 6.2 & 7.4 & 5 \\
\hline $\begin{array}{l}\text { conduct- } \\
\text { ance }\end{array}$ & (jimhos) $3 /$ & 557 & 1,020 & 1,240 & 5 & 1,210 & 1,760 & 4,280 & 5 \\
\hline $\begin{array}{l}\text { Sulfate } \\
\text { Alkalinity- } \\
\text { sulfate } \\
\text { ratio }\end{array}$ & $\begin{array}{l}(\mathrm{mg} / \mathrm{L}) \\
\text { (dimen- } \\
\text { sionless) }\end{array}$ & 170.24 & $\begin{array}{r}320 \\
.46\end{array}$ & $\begin{array}{r}530 \\
.76\end{array}$ & $\begin{array}{l}5 \\
5\end{array}$ & $\begin{array}{r}450 \\
.01\end{array}$ & $\begin{array}{r}1,030.20\end{array}$ & $\begin{array}{r}2,150.57\end{array}$ & $\begin{array}{l}5 \\
4\end{array}$ \\
\hline $\begin{array}{l}\text { Iron } \\
\text { Zinc } \\
\text { Cadmium } \\
\text { Lead } \\
\text { Silica }\end{array}$ & $\begin{array}{l}(\mu \mathrm{g} / \mathrm{L}) \\
(\mu \mathrm{g} / \mathrm{L}) \\
(\mu \mathrm{g} / \mathrm{L}) \\
(\mu \mathrm{g} / \mathrm{L}) \\
(\mathrm{mg} / \mathrm{L})\end{array}$ & $\begin{array}{l}10 \\
0 \\
0 \\
6\end{array}$ & $\begin{array}{r}60 \\
1,100 \\
1 \\
0 \\
8\end{array}$ & $\begin{array}{r}1,500 \\
4,200 \\
12 \\
0 \\
14\end{array}$ & $\begin{array}{l}5 \\
5 \\
5 \\
5 \\
5\end{array}$ & $\begin{array}{r}15 \\
35 \\
0 \\
0 \\
8\end{array}$ & $\begin{array}{c}1,750 \\
4,750 \\
4.5 \\
5 \\
11\end{array}$ & $\begin{array}{r}283,100 \\
23,400 \\
45 \\
70 \\
44\end{array}$ & $\begin{array}{l}5 \\
5 \\
5 \\
5 \\
5\end{array}$ \\
\hline
\end{tabular}

1 Data from sites $2,3,13,15$, and 16 (figure 3 ).

Data from sites $9,10,11,12$, and 17 (figure 3 ).

3 Micromhos per centimeter at $25^{\circ}$ Celsius. 
Mine waters in the Picher Field typically are stratified. Table 13 shows that the largest specific-conductance values and concentrations of iron, manganese, zinc, and sulfate and the lowest $\mathrm{pH}$ occurred in water from the lower anoxic part of the stratified mine waters. When water is discharged at the surface from drill holes, which intercept the mine water in lower levels of the mines, ferric iron and acid are produced as a result of oxidation and hydrolysis reactions shown in equations 2 and 3 . Large concentrations of trace metals also occur in these discharges. It may be inferred that drill holes that discharge from the upper levels of the mines may not produce appreciable quantities of acid-mine water.

There are very little data available to predict future water-quality changes in mines in the Picher Field. However, comparison of samples collected during 1976 and 1977 by Playton and others (1978) from the lower level of the Consolidated No. 2 mine in Oklahoma with samples collected by the Oklahoma Water Resources Board (1981) during 1980 and 1981 (fig. 17) indicates that zinc, lead, and cadmium concentrations decreased. Concentrations of iron and sulfate, which appear to be inversely related to $\mathrm{pH}$, have fluctuated but have not decreased significantly.

Krauskopf (1967, p. 516) shows that the sulfide iron ( $S^{2-}$ ), which is known to be present in well waters in the confined shallow aquifer in other parts of the western area, limits concentrations of zinc, cadmium, lead, and some other trace metals, but not iron or manganese, in water with a $\mathrm{pH}$ of 3. Thus, movement of water containing hydrogen sulfide $\left(\mathrm{H}_{2} \mathrm{~S}\right)$ from the shallow aquifer or production of $\mathrm{H}_{2} \mathrm{~S}$ in the mines appears to be the most likely explanation of decrease of zinc, cadmium, and lead under conditions of low $\mathrm{pH}$ (fig. 17), although precipitation of hydrates and carbonates of compounds containing these trace metals also is possible.

Large concentrations of iron and sulfate could be maintained in the mines for long periods of time, even with small concentrations of oxygen. This is because pyrite and marcasite, which are present in the ore deposits in the mines (McKnight and Fischer, 1970, p. 113-116), may be rapidly oxidized by ferric iron $\left(\mathrm{Fe}^{3+}\right.$ ) to produce ferrous iron sulfate (Stumm and Morgan, 1970, p. 541). However, solubility of iron, as well as other trace-metal constituents, could be limited if enough bicarbonate and carbonate ion are present to neutralize acidity created by oxidation of sulfide minerals. This could occur if these ions enter the mines in water from unmined carbonate rocks adjacent to the mines or if 1 imestone $\left(\mathrm{CaCO}_{3}\right)$ is dissolved from rocks in the mines and the mine walls. Only future monitoring through time, however, will yield reliable information on changes in the chemical quality of these mine waters.

In the absence of detailed sampling and site-specific drill-hole placement, it is difficult to evaluate the extent of lateral movement of water from the mines. However, water from shallow wells sampled for this study in the eastern area, located adjacent to and downgradient from the mines and generally in the limestone areas, did not exceed the maximum contaminant concentrations set for zinc and cadmium (table 7). Largest observed concentrations of these constituents may be the result of localized dissolution of sulfide deposits near the well. These results are consistent with the findings of Barks (1977) who reported that contaminated water was apparently 
Table 13.--Comparison of selected chemical constituents and physical properties of water for upper and lower levels of mines in the Picher Field, Kansas and Oklahoma

[Values given in milligrams per liter (mg/L) and micrograms per liter ( $\mu \mathrm{g} / \mathrm{L})$, except as noted]

\begin{tabular}{|c|c|c|c|c|c|c|c|c|c|}
\hline \multirow[b]{2}{*}{$\begin{array}{l}\text { Chemical con- } \\
\text { stituent or } \\
\text { physical } \\
\text { property }\end{array}$} & \multirow[b]{2}{*}{$\begin{array}{l}\text { Unit } \\
\text { of } \\
\text { measure- } \\
\text { ment }\end{array}$} & \multicolumn{4}{|c|}{ Upper level } & \multicolumn{4}{|c|}{ Lower level } \\
\hline & & Minimum & Median & Maximum & $\begin{array}{l}\text { Number } \\
\text { of } \\
\text { samples }\end{array}$ & Minimum & Median & Maximum & $\begin{array}{l}\text { Number } \\
\text { of } \\
\text { samples }\end{array}$ \\
\hline pH & (units) & 3.1 & 6.6 & 8 & 11 & 2.2 & 6.2 & 7.1 & 8 \\
\hline $\begin{array}{l}\text { Specific } \\
\text { conduct- } \\
\text { ance }\end{array}$ & $(\mu \text { mhos })^{1 /}$ & 65 & 1,123 & 2,340 & 11 & 1,220 & 2,145 & 4,280 & 8 \\
\hline $\begin{array}{c}\text { Dissolved } \\
\text { oxygen }\end{array}$ & $(\mathrm{mg} / \mathrm{L})$ & 1.9 & 5.8 & 8.8 & 10 & .4 & .9 & 5.2 & 7 \\
\hline Sulfate & $(\mathrm{mg} / \mathrm{L})$ & 124 & 460 & 1,500 & 11 & 450 & 1,170 & 3,050 & 8 \\
\hline Iron & $(\mu \mathrm{g} / \mathrm{L})$ & 10 & 50 & 6,200 & 11 & 10 & 13,050 & 560,000 & 8 \\
\hline Manganese & $(\mu \mathrm{g} / \mathrm{L})$ & 30 & 250 & 6,400 & 11 & 20 & 1,045 & 4,100 & 8 \\
\hline Zinc & $(\mu \mathrm{g} / \mathrm{L})$ & 10 & 940 & 4,600 & 11 & 20 & 4,150 & 43,000 & 8 \\
\hline Cadmi um & $(\mu \mathrm{g} / \mathrm{L})$ & 0 & 5 & 12 & 11 & 0 & 5 & 85 & 8 \\
\hline Lead & $(\mu \mathrm{g} / \mathrm{L})$ & 0 & 0 & 40 & 11 & 0 & 0 & 100 & 8 \\
\hline Silica & $(\mathrm{mg} / \mathrm{L})$ & 4 & 11 & 45 & 11 & 6 & 9.5 & 17 & 6 \\
\hline
\end{tabular}

\footnotetext{
1 Micromhos per centimeter at $25^{\circ}$ Celsius.
} 


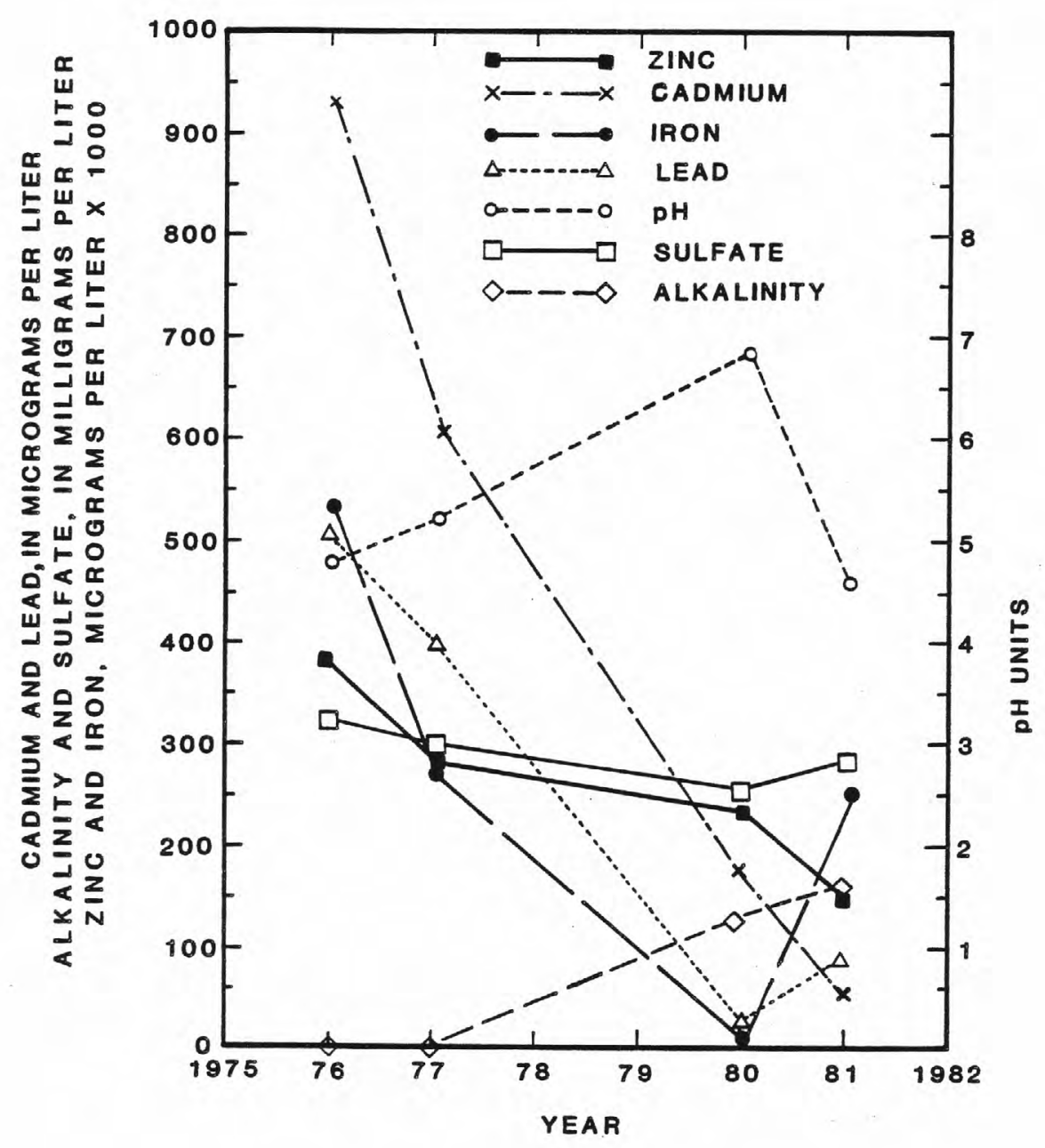

Figure 17.--Changes through time in selected chemical constituents and physical properties in samples from lower level of Consolidated No. 2 mine, Oklahoma. Samples were obtained at depths of more than 200 feet below 1 and surface.

confined to the mines. No wells could be located in the shallow aquifer downgradient from or near the mined areas for. sampling in the western area. As al ready noted, most residents use either water from the Cherokee Group or water from the deep aquifer. It may be inferred from information in Krauskopf (1967, p. 516), however, that some fraction of chemical constituents such as zinc, cadmium, and lead could precipitate in the presence of the carbonate or sulfide ion, both of which are present in the shallow aquifer (as well as the deep aquifer) in the western area. The presence of the carbonate, bicarbonate, and sulfide ions, therefore, could possibly limit concentrations of trace metals away from the mines.

It is difficult to evaluate whether contamination of the deep aquifer has taken place for two reasons. The first is that the deep wells are "open-hole" through several hundred feet, making areal comparisons difficult because vertical differences in water quality and hydraulic characteristics may be reflected by an analysis from a well. Thus, even though a well may 
exhibit relatively large sulfate concentrations, for example, this may be due to contributions of water from rock units within the deep aquifer, rather than from the overlying shallow aquifer. Without segregation of individual rock units in the deep aquifer, definitive conclusions are difficult to draw.

The second reason is that leakage may occur in the annular space around the well allowing vertical movement of water. In addition, leakage may occur at breaks in the casing, whether caused by corrosion or by casing joints that are not watertight. This problem was discussed by Williams (1948). Thus, it is difficult to discern whether widespread contamination is taking place or whether individual wells are somehow faulty and are allowing vertical leakage from the shallow aquifer.

Examination of figure 16 indicates that wells near Baxter Springs and Treece, Kansas, and Picher, Oklahoma, exhibit relatively large percentages of sulfate. However, the wells sampled for this study at Baxter Springs, Kansas, and Picher, Oklahoma, do not exhibit large concentrations of zinc or cadmium (wells 217, 219, 220, and 225; table 22 at the end of this report). Only a deep well with a leaky casing or one that was located near a well open to the shallow aquifer [fig. 12(B) and (E)] would be likely to produce water with large trace-metal concentrations. For reasons stated above, it cannot be shown conclusively that the water in the deep aquifer is contaminated by water from a shallow aquifer. However, if contamination were occurring, either locally or regionally, the water-quality deterioration would be statistically observable through time.

Because sulfate is a highly mobile ion and the least susceptible to changes in sample collection and analysis through time, sulfate data from six water-supply wells at Columbus, Crestline, Galena, Treece, and Baxter Springs, Kansas, were tested for trend with a Spearman-rho test (Conover, 1971). Results of the Spearman-rho test are shown in figure 18.

The Spearman correlation coefficient (rho) measures the degree of correlation of ranked values of the independent variable (year) with the dependent variable (sulfate concentration). If a positive correlation or increasing trend exists, the Spearman rho will be positive and will approach 1. A perfect positive correlation would be 1 ; no correlation would be indicated by 0 ; and a perfect negative correlation would approach -1 . The Spearman rho is a nonparametric test and is, therefore, not influenced by the distribution of the data (Conover, 1971). The level of significance is indicated by the number below the Spearman-rho coefficient shown in figure 18 and indicates the probability that a trend would be indicated due to chance alone. Thus, a level of significance of 0.10 indicates that there is a 10-percent chance that the observed correlation is due to chance al one (that is, there is a 10-percent chance that there really is no trend). To be 95-percent certain that the trend is "real," a significance level of 0.05 (or 5 percent) would be acceptable.

A positive trend in sulfate concentrations is indicated in wells at Crestline, Galena, Baxter Springs, and Treece, Kansas; all of these wells are located near former lead-zinc mine areas. The two wells located north 
and west of the mining districts (fig. 18, D and E) do not show a significant trend. This may be due to the fact that sulfate concentrations in the overlying shallow aquifer are low in this area. The most significant increase in sulfate concentrations is at the Treece public-supply well, which increased from 20 to $120 \mathrm{mg} / \mathrm{L}$ in 19 years. Use of this well was terminated in the early 1970's due to a strong hydrogen-sulfide odor associated with water from this well (Jack Burris, Kansas Department of Health and Environment, oral commun., 1982). Although an increasing trend is indicated in four of the wells, sulfate concentrations in water from these wells are well below the suggested maximum concentration of $250 \mathrm{mg} / \mathrm{L}$ (U.S. Environmental Protection Agency, 1977).

As noted, it is difficult, based on available information, to conclusively determine whether the increase in sulfate concentrations in the deep aquifer is due to localized movement of water from the shallow aquifer through leaky casings or whether it is due to an increase in concentrations in the deep aquifer from regional leakage. A variety of evidence, however, suggests leaky well casings are the principal cause of the trends observed. A well at Picher, Oklahoma, which started producing water with large sulfate concentrations, was recased, and sulfate concentrations decreased to normal (R. W. Fairchild, U.S. Geological Survey, oral commun., 1982).

A further indication that leaky well casings are at fault is suggested by data from three wells sampled at Baxter Springs, Kansas (wells 219,220 , and 225, fig. 3). Well 220 was the only well in the deep aquifer that produced a calcium sulfate type water (fig. 16). The sample from this well (table 22 near the end of this report) contained $230 \mathrm{mg} / \mathrm{L}$ of sulfate, a concentration that was almost three times larger than the largest concentration observed in water from other wells in the deep aquifer. The abnormally large sulfate concentration in well 220 strongly suggests.leakage from the shallow aquifer. This well also contained the largest observed dissolved-calcium concentration (table 22). Examination of well-construction records showed that this is the only well of the three that has a casing joint in the shallow aquifer. This suggests that some of the calcium and sulfate ions in water from well 220 could be derived from the shallow aquifer; calcium concentrations are more than $200 \mathrm{mg} / \mathrm{L}$, and sulfate concentrations are more than $400 \mathrm{mg} / \mathrm{L}$ at the two well $\mathrm{s}$ in the shallow aquifer (well 117, table 20, and well 127, table 24 near the end of this report) located near the Pennsylvanian-Mississippian geologic contact north of Baxter springs. Additionally, most of the public-supply wells sampled were constructed before 1940, and deterioration of well casings through time could allow leakage of water from the shallow aquifer into the well.

\section{Surface Water}

\section{Regional Characteristics}

Low-flow chemical-quality characteristics from all surface-water sampling sites in the study area in Kansas that had chemical-quality data available and from selected sampling sites in Missouri are shown in figure 19. Availability of chemical-quality data from streams in the study area 

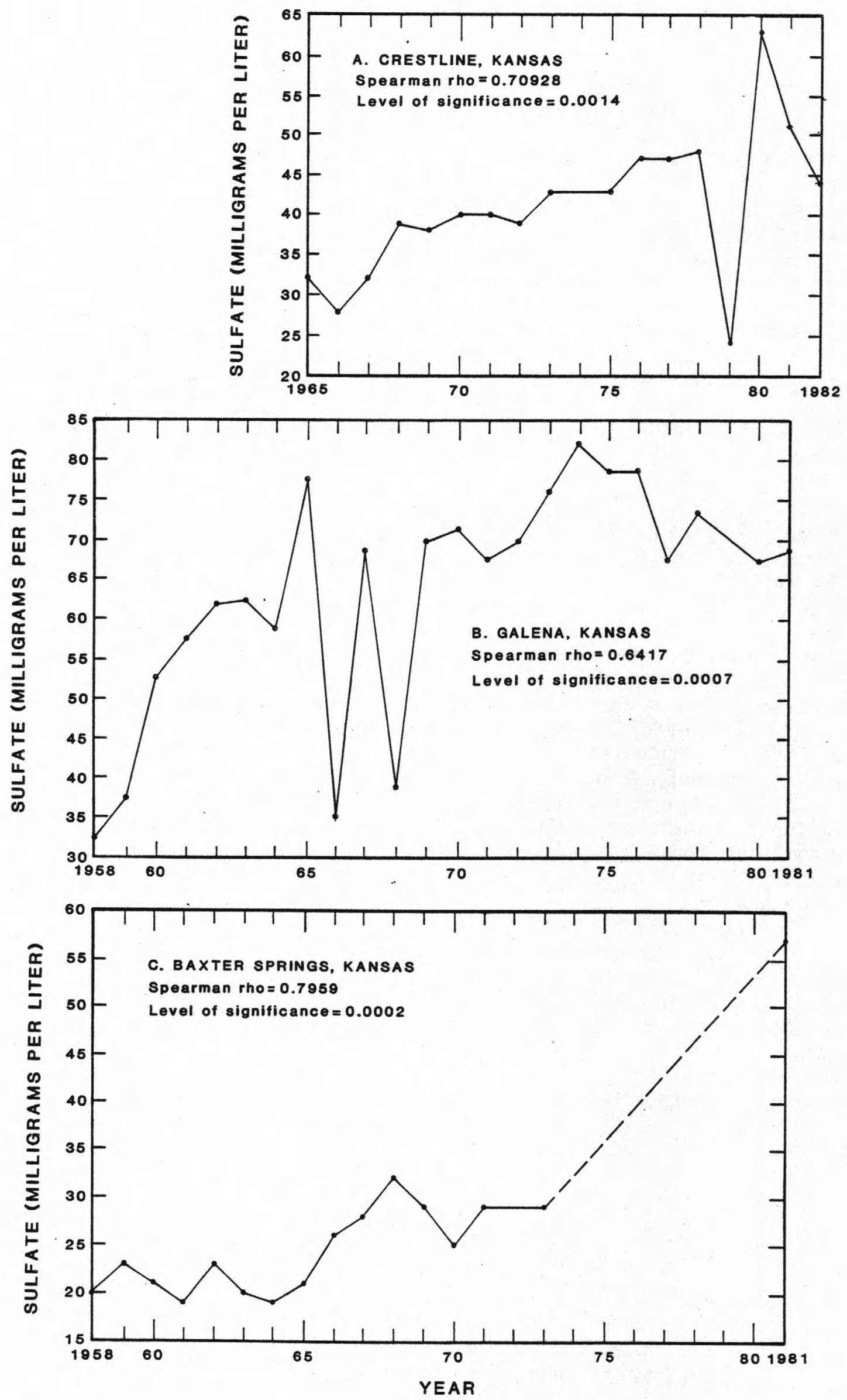

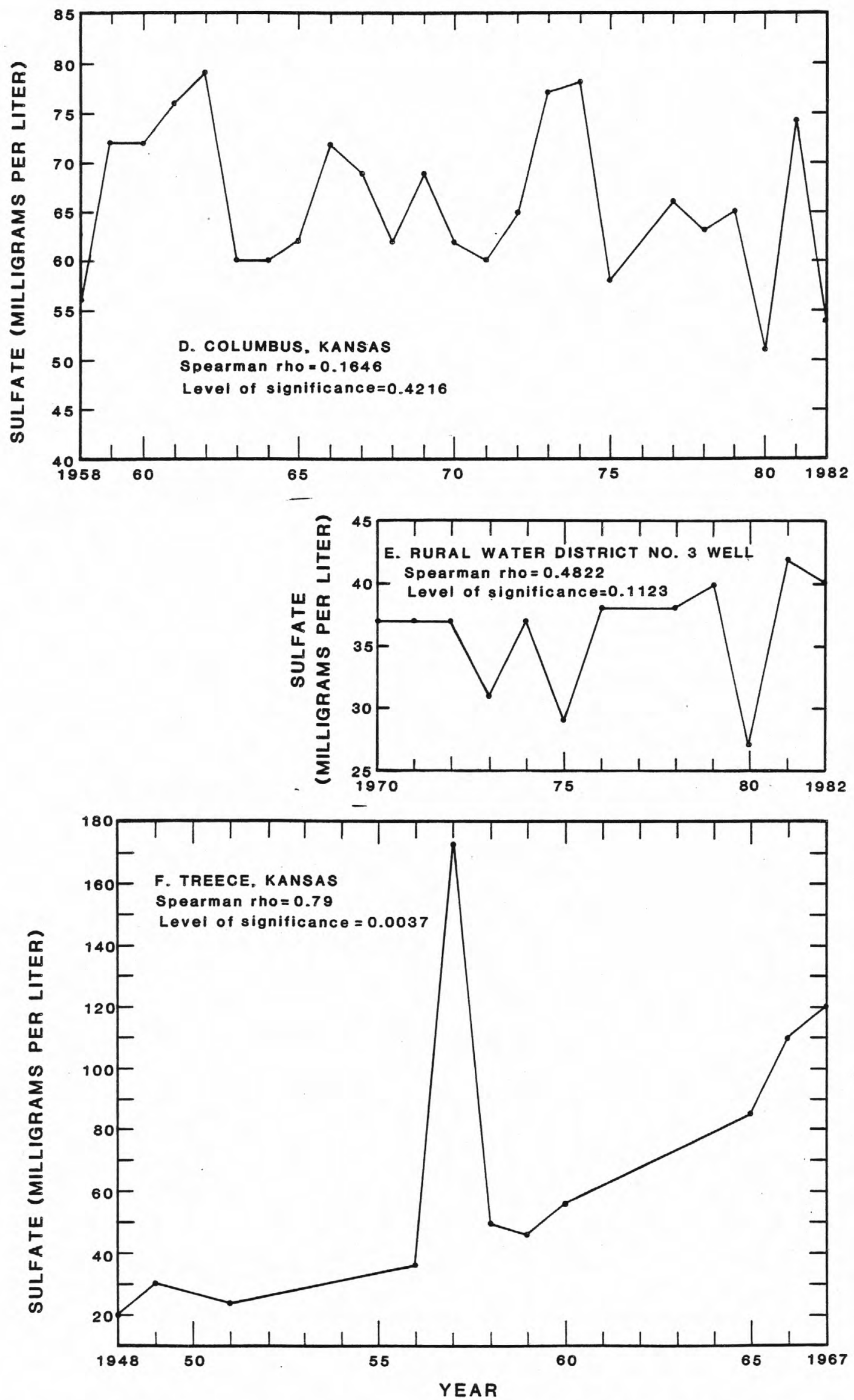

Figure 18.--Sulfate concentrations in water from selected public-supply wells. 


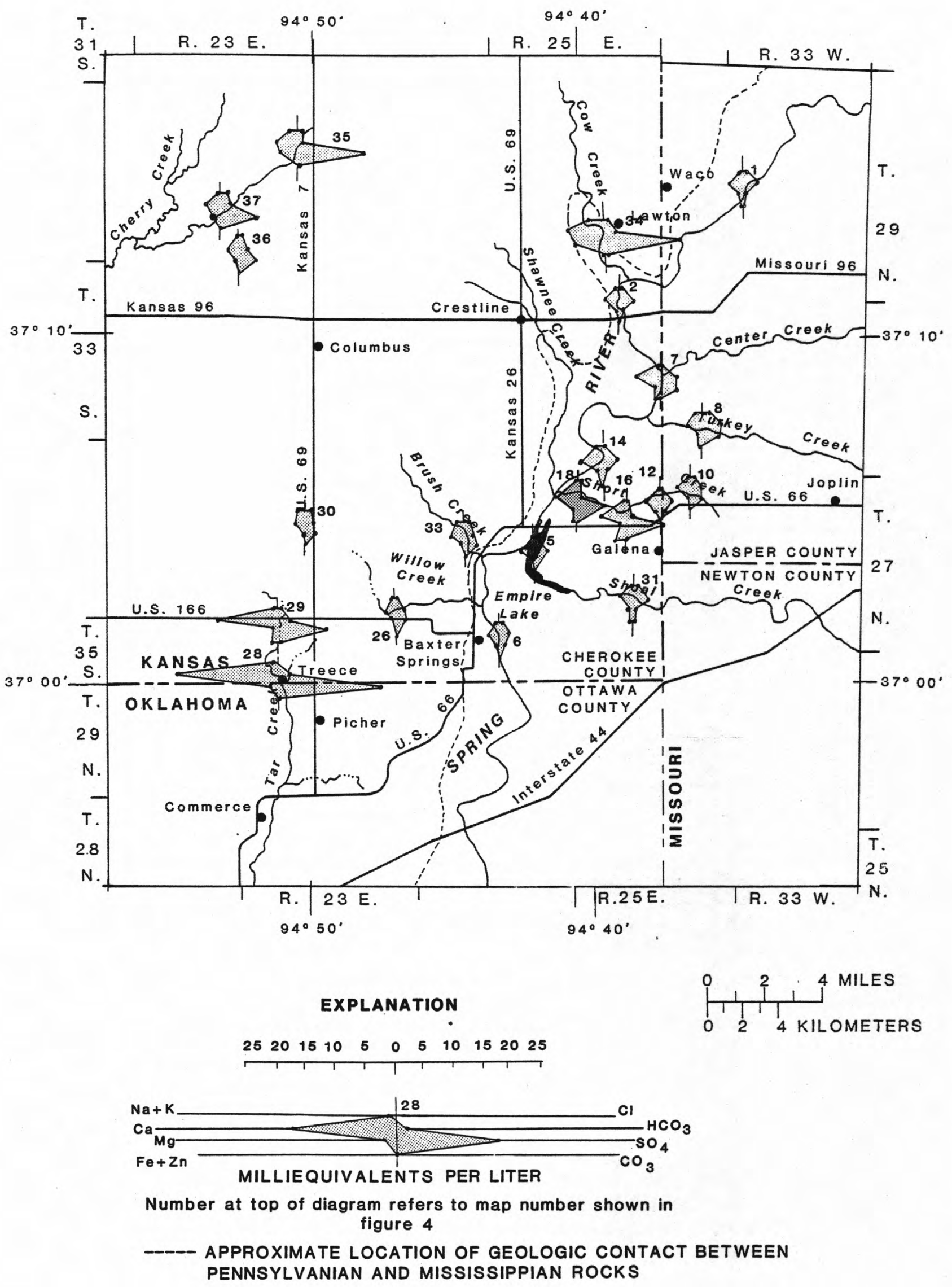

Figure 19.--Chemical-quality characteristics of selected streams in study area. 
was extremely limited, and, in most cases, only one or two analyses, which would represent low-flow chemical water quality, were available for each stream. Low-flow chemical-quality data indicate maximum mineral contributions from rocks, soils, and discharges from mines or chat-pile seepage. Because little or no mining occurred in the watershed above sampling sites $26,1 / 30,1 / 31,33$, and $1 / 36$ (fig. 19), chemical water-quality data from these sites probably best represent chemical water-quality characteristics unaffected by mining.

In order to statistically characterize low-flow chemical quality of small streams in the study area, low-flow chemical water-quality data from selected sampling sites on four streams in the eastern area (sampling sites $7,8,18$, and $1 / 31$, fig. 4) and on five streams in the western area (sampling sites $24,28,1 / 31,1 / 34$, and $1 / 37$, fig. 4) were summarized (table 14). One chemical analysis from a sample collected during low flow was selected to represent chemical-quality characteristics of each stream. The chemical analysis included for each stream in the data summary in table 14 was selected from the most downstream sampling site on each tributary of the Spring River within the eastern and western area boundaries and the most downstream sampling site on Cherry Creek before exiting the study area and on Tar Creek before exiting the study area in Kansas. The following discussion refers only to the nine sampling sites included in the statistical data summary.

Streams in the eastern area contain a calcium bicarbonate (sampling site 31, fig. 19) or a calcium bicarbonate sulfate (sampling sites 7 and 8, fig. 19) type water with a specific conductance of generally less than 600 micromhos (micromhos per centimeter at $25^{\circ}$ Celsius) and median dissolved concentrations of most trace elements, except zinc and manganese, of less than $20 \mu \mathrm{g} / \mathrm{L}$. The chemical analysis for Short Creek, 2 miles west of Galena (sampling site 18, fig. 4; table 23 at the end of this report), exhibited the largest concentrations of sulfate, all trace elements, and the lowest $\mathrm{pH}(6.0)$. Short Creek contains a calcium sulfate type water, as indicated in figure 19 (sampling site 18).

Streams draining the western area contain calcium sulfate or calcium sodium sulfate bicarbonate type waters (fig. 19) and exhibit a specific conductance ranging between 375 and 1,530 micromhos (table 14). Maximum iron and manganese concentrations shown in table 14 may be due to drainage from pyritic rock and residual soils, although most streams in this area are affected by either abandoned coal or lead and zinc mines.

\section{Effects of Abandoned Mines}

Streams in the eastern area, which drain watersheds underlain by rocks of Mississippian age, contain larger concentrations of dissolved sulfate, zinc, cadmium, and manganese in areas downstream from abandoned lead-zinc

1 Data published in U.S. Geological Survey, 1976-79. 
Table 14.--Summary of low-flow water-quality data for selected streams in study area1

[Values given in milligrams per liter $(\mathrm{mg} / \mathrm{L})$ and micrograms per liter $(\mu \mathrm{g} / \mathrm{L})$, except as noted]

Chemical Unit

constituent of Minimum Median Maximum

or physical measure-

ment

Eastern area

property
Num- Minimum Median Maximum ber

of

sam-

ples
Western area

Num

ber

of

sam

ples

$283 \quad 540$

730

$4 \quad 375$

1,300

1,530

ductance

Discharge

$\mathrm{pH}$

$\left(\mathrm{ft}^{3} / \mathrm{s}\right)$
(units)
(degrees
Celsius)
$(\mathrm{mg} / \mathrm{L})$
$(\mathrm{mg} / \mathrm{L})$
$(\mathrm{mg} / \mathrm{L})$
$(\mathrm{mg} / \mathrm{L})$
$(\mathrm{mg} / \mathrm{L})$
$(\mathrm{mg} / \mathrm{L})$
$(\mathrm{mg} / \mathrm{L})$
$(\mathrm{mg} / \mathrm{L})$
$(\mathrm{mg} / \mathrm{L})$

Temperature

3/

$\begin{array}{ccc}5 & 31 & 250 \\ 6.0 & 7.7 & 8.3 \\ 22.8 & 25 & 28\end{array}$

4

4.08

2.2
7.5

14.8

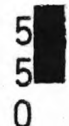

Calcium

Magnesium

Sodium

Potassium

Alkalinity

Sulfate

Chloride

Fluoride

Silica

Dissolved

solids

Nitrate-

nitrogen

Arsenic

Barium

Cadmium

Copper

Iron

Lead

Manganese

Selenium

Zinc

$(\mathrm{mg} / \mathrm{L})$

(mg/L)

$\begin{array}{cccc}50 & 71 & 89 & 3 \\ 1.8 & 5.3 & 6.5 & 4 \\ 4.7 & 11.2 & 31 & 4 \\ 1.6 & 3.7 & 9 & 4 \\ <10 & 120 & 160 & 4 \\ 9 & 130 & 240 & 4 \\ 9 & 10.5 & 36 & 4 \\ .17 & -- & -- & 1 \\ 8 & 9 & 17 & 4\end{array}$

165

$1.2 \quad-\overline{1.8} \quad \overline{7.4}$

27

6.9

130

6.9

1.1

0

72

1

$5^{.3}$

21

53

4

4

4

4

5

4.2
64
620
18
6
6

963

4

0

$--$

370

63

65

$(\mu \mathrm{g} / \mathrm{L})$
$(\mu \mathrm{g} / \mathrm{L})$
$(\mu \mathrm{g} / \mathrm{L})$
$(\mu \mathrm{g} / \mathrm{L})$
$(\mu \mathrm{g} / \mathrm{L})$
$(\mu \mathrm{g} / \mathrm{L})$
$(\mu \mathrm{g} / \mathrm{L})$
$(\mu \mathrm{g} / \mathrm{L})$
$(\mu \mathrm{g} / \mathrm{L})$

$\begin{array}{rrr}-- & -- & -- \\ 0 & 0 & 0 \\ 0 & 0 & 170 \\ 0 & 10 & 20 \\ 10 & 15 & 20 \\ 0 & 0 & 0 \\ 20 & 90 & 1,700 \\ -- & -- & -\overline{0} \\ 110 & 200 & 25,000\end{array}$

0
3
3
4
4
3
4
0
4

0
0
0
0
20
0
40
--
20

$\begin{array}{rr}-- & -- \\ -- & -- \\ 0 & 40 \\ 0 & 10 \\ 80 & 1,100 \\ 0 & 0 \\ 170 & 6,300 \\ -- & =- \\ 180 & 5,800\end{array}$

1 Low-flow data from streams with drainage areas of greater than 10 square miles were used. Data from streams, with the exception of Tar Creek in the western area, and Shoal Creek in the eastern area, were collected between 1976 and 1979. All other data were obtained during August 1981.

2 Micromhos per centimeter at $25^{\circ}$ Celsius.

3 Cubic feet per second. 
mines than in areas upstream from the mines. This may be seen by comparison of samples collected by Barks (1977, tables 12 and 13, p. 45-48) from sites upstream and downstream from mined areas on Center Creek in Missouri. Analyses of samples obtained from the upstream station (Center Creek near Fidelity, Missouri) contained the following maximum dissolved concentrations: sulfate $(8.2 \mathrm{mg} / \mathrm{L})$, zinc $(20 \mu \mathrm{g} / \mathrm{L})$, cadmium $(1 \mu \mathrm{g} / \mathrm{L})$, and manganese (less than $10 \mu \mathrm{g} / \mathrm{L}$ ). Maximum dissolved concentrations observed at the most downstream station. (Center Creek near Smithfield, Missouri) were sulfate $(64 \mathrm{mg} / \mathrm{L})$, zinc $(700 \mu \mathrm{g} / \mathrm{L})$, cadmium $(7 \mu \mathrm{g} / \mathrm{L})$, and manganese $(80 \mu \mathrm{g} / \mathrm{L})$.

Water samples collected during low-flow conditions during August 1981, from Turkey, Center, and Short Creeks (sampling sites 7, 8, and 18, fig. 4 and table 23 at the end of this report), which are tributaries to the Spring River in the eastern area, contained concentrations of sulfate and trace metals indicative of lead-zinc mine drainage. Short Creek (sampling site 18, fig. 4) exhibited the most severe water-quality effects of mine drainage. Compared with water samples from three other major streams in the eastern area (table 14), a sample collected from Short Creek contained the maximum dissolved concentrations of sulfate (240 $\mathrm{mg} / \mathrm{L})$, zinc $(25,000 \mu \mathrm{g} / \mathrm{L})$, cadmium $(170 \mu \mathrm{g} / \mathrm{L})$, manganese $(1,700 \mu \mathrm{g} / \mathrm{L})$, and the lowest $\mathrm{pH}(6.0)$. The calcium sulfate type water in this stream (fig. 19) further indicates severe effects of drainage from abandoned lead and zinc mines.

A seepage investigation was conducted on Short Creek during August 1981, to determine major chemical inputs along the stream. Chemical types of water from four sampling sites on Short Creek (see fig. 4) are shown on Collins diagrams in figure $20(\mathrm{~A})$, and downstream concentrations of calcium $(\mathrm{Ca})$, bicarbonate $\left(\mathrm{HCO}_{3}\right)$, sulfate $\left(\mathrm{SO}_{4}\right)$, lead $(\mathrm{Pb})$, zinc $(\mathrm{Zn})$, cadmium $(\mathrm{Cd})$, iron ( $\mathrm{Fe})$, and manganese $(\mathrm{Mn})$ and streamflow (Q) are shown in figure $20(B)$. The following discussion is based on data shown in figure 20. Interpretations based on figure 20 were checked and are consistent with mass-balance calculations shown in table 26 in the "Supplementary Information" section.

Site 10 exhibited a calcium bicarbonate sulfate type water, with relatively small dissolved-solids concentrations and small concentrations of trace elements. Site 11 is located approximately 0.5 mile downstream. Figures $20(A)$ and $(B)$ indicate a calcium sulfate bicarbonate type water with significant increases in calcium, sulfate, zinc, cadmium, and manganese, and with moderate increases in iron at this site. The increases in sulfate, zinc, and cadmium at site 11 reflect ground-water inflows from rocks in the mined area. Site 16, located approximately 1 mile downstream from site 11, exhibited a calcium sulfate type water with the greatest increases in zinc (147x), cadmium (290x), and manganese (88x). Three tributary streams (sites 12-14) contributed only $0.35 \mathrm{ft}^{3} / \mathrm{s}$, or approximately 22 percent of the $1.6 \mathrm{ft}^{3} / \mathrm{s}$ gain in discharge between sites 11 and 16, indicating ground-water inflow from the breccia and mines accounted for 78 percent of the gain. The large increase in manganese concentrations at site 16, however, may be due to creation of geochemical conditions (due to discharge of acid ground water) conducive to dissolution of manganese from the streambed or from vegetation. Concentrations of dissolved manganese in mines in the eastern area (table 8) would not 

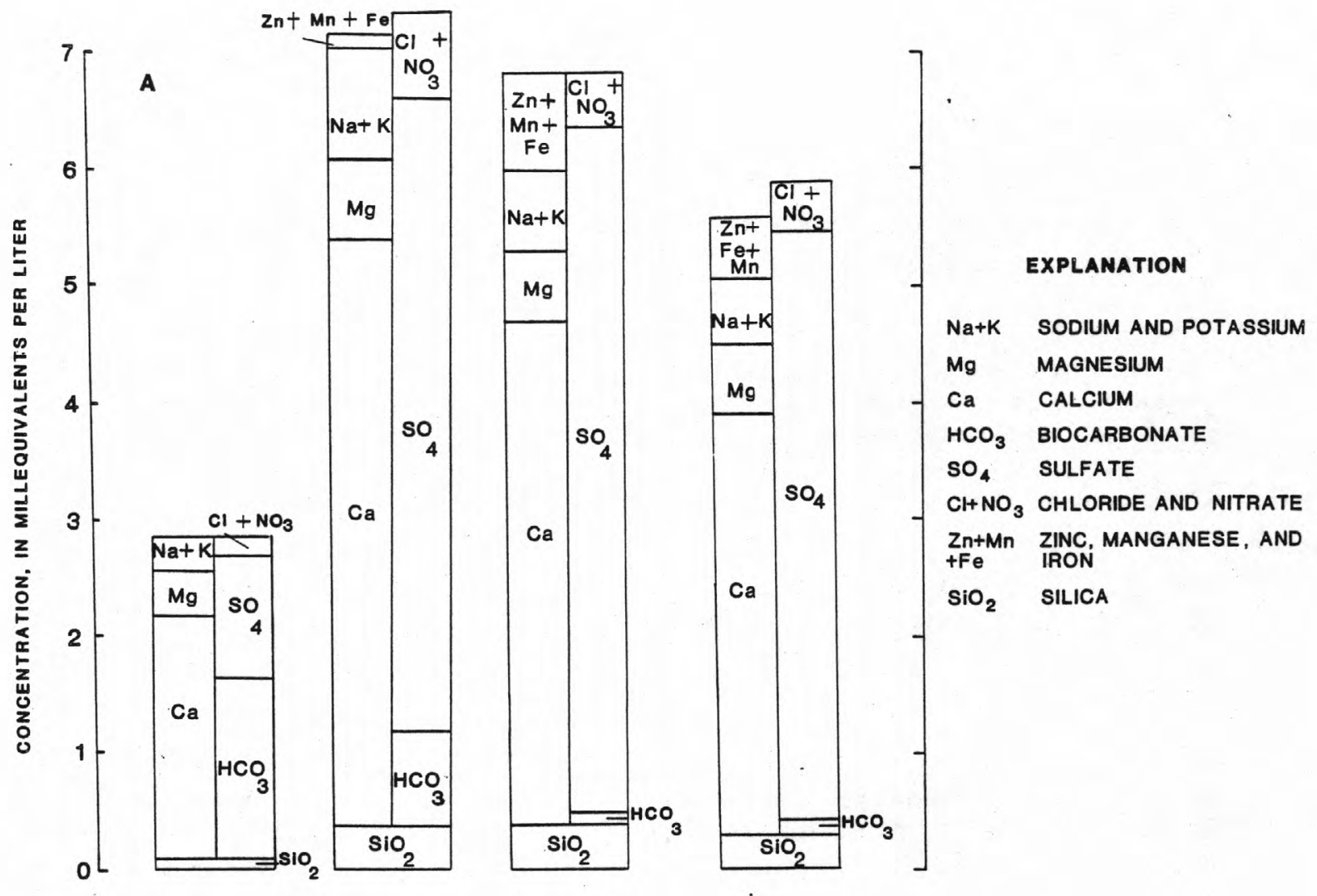

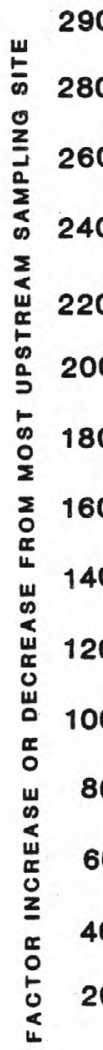

\section{B}

290

EXPLANATION

ACTUAL CONCENTRATIONS FOR EACH CONSTITUENT GIVEN AT TOP OF BARS.

UNITS OF MEASUREMENT FOR

CALCIUM $(\mathrm{Ca})$, BICARBONATE $\left(\mathrm{HCO}_{3}\right)$ AND SULFATE (SO4), IN MILLIGRAMS PER LITER (mg/L) ; LEAD (Pb), ZINC $(\mathrm{Zn})$, CADIUM (Cd), IRON (Fe), AND MANGANESE (Mn), IN MICROGRAMS MANGANESE $(M n)$, IN MICROGRAMS IN CUBIC FEET PER SECOND

INFLOW FROM TRIBUTARY $\sqrt{\text { STREAMS }}$

$40-\frac{4}{20}$
0
0
0

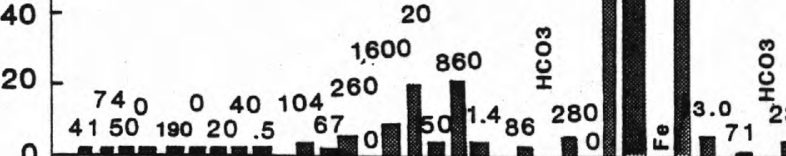
SITES $12-14$ $Q=0.35$ $\sqrt{ }$

$60-$

$40-$ SITE 17 , $\underset{Q=1.7}{\operatorname{SiTE}}$ 
account for the large concentrations (more than $1,000 \mu \mathrm{g} / \mathrm{L}$ ) observed in Short Creek. Thus, based on the available data, the mines do not appear to be the primary source of dissolved manganese in the stream, although discharge of acid ground water from the mined areas may allow manganese to enter into solution.

Zinc, cadmium, and manganese concentrations decreased at the next sampling site (site 18), which is located 1.5 miles downstream from site 16 and 1 mile from the mouth of Short Creek. The mass-balance calculations shown in table 26 confirm that loss of zinc, cadmium, and manganese was occurring in Short Creek; loads at site 18 were less than cumulative loads of sites 16 and 17. This decrease may be attributed possibly to active uptake or adsorption of trace elements by algae, which entirely covers the bed of the stream. It is also possible that massive growths of algae may cause decreases in dissolved concentrations of metals due to local precipitation in the stream during the growing season as a result of oxygen production and elevated $\mathrm{pH}$ during the day caused by photosynthetic processes. Because the channel at site 18 is relatively wide and shallow and has a larger surface area on the bed for algal growths than upstream sampling sites, more dissolved zinc and cadmium possibly may be removed. Sorption of trace metals onto ferric oxyhydroxides on the streambed or inorganic chemical reactions also could account for the observed decrease.

Possible sources of trace minerals in Short Creek also may be evaluated by examination of the relationship of sulfate and total and dissolved concentrations of iron, lead, zinc, and cadmium to discharge (fig. 21). Dissolved concentrations of zinc, cadmium, and sulfate in water collected from Short Creek at Galena (site 16, fig. 4 and table 24 at the end of this report) appear to be inversely related to discharge, with largest concentrations occurring at low flow. The dissolved concentrations of zinc and cadmium also comprised 70 percent or more of the total concentration observed at all three discharges shown in figure 21 . . These data suggest that sulfate, zinc, and cadmium are derived primarily from inflow of ground water from the breccia, mines, and seepage from chat piles in the Short Creek basin.

Total lead and iron concentrations, which consist almost entirely of suspended material (fig. 21), increase with discharge, indicating that these constituents are associated with sediment. Red ferric-oxyhydroxide deposits ("yellow boy") generally were not observed on the bed of Short Creek. The absence of iron-oxide stains on the streambed suggests that relatively low concentrations of ferrous iron, which discharge from mines, precipitate as ferric oxide; generally, iron concentrations in the mines sampled in the Galena Field were less than $100 \mu \mathrm{g} / \mathrm{L}$. The large suspendediron concentrations at high flows suggest transport of ferric oxyhydroxides derived from mine drainage or possibly pyritic soils or organic debris. Lead possibly occurs on the streambed either as a precipitate derived partially from seepage from chat or from discharge of mine water, which contains large dissolved concentrations of lead or, more likely, from particulate lead compounds associated with chat piles.

It should be noted that analyses of water samples obtained from Short Creek during low-flow conditions during 1979 and before (U.S. Geological 

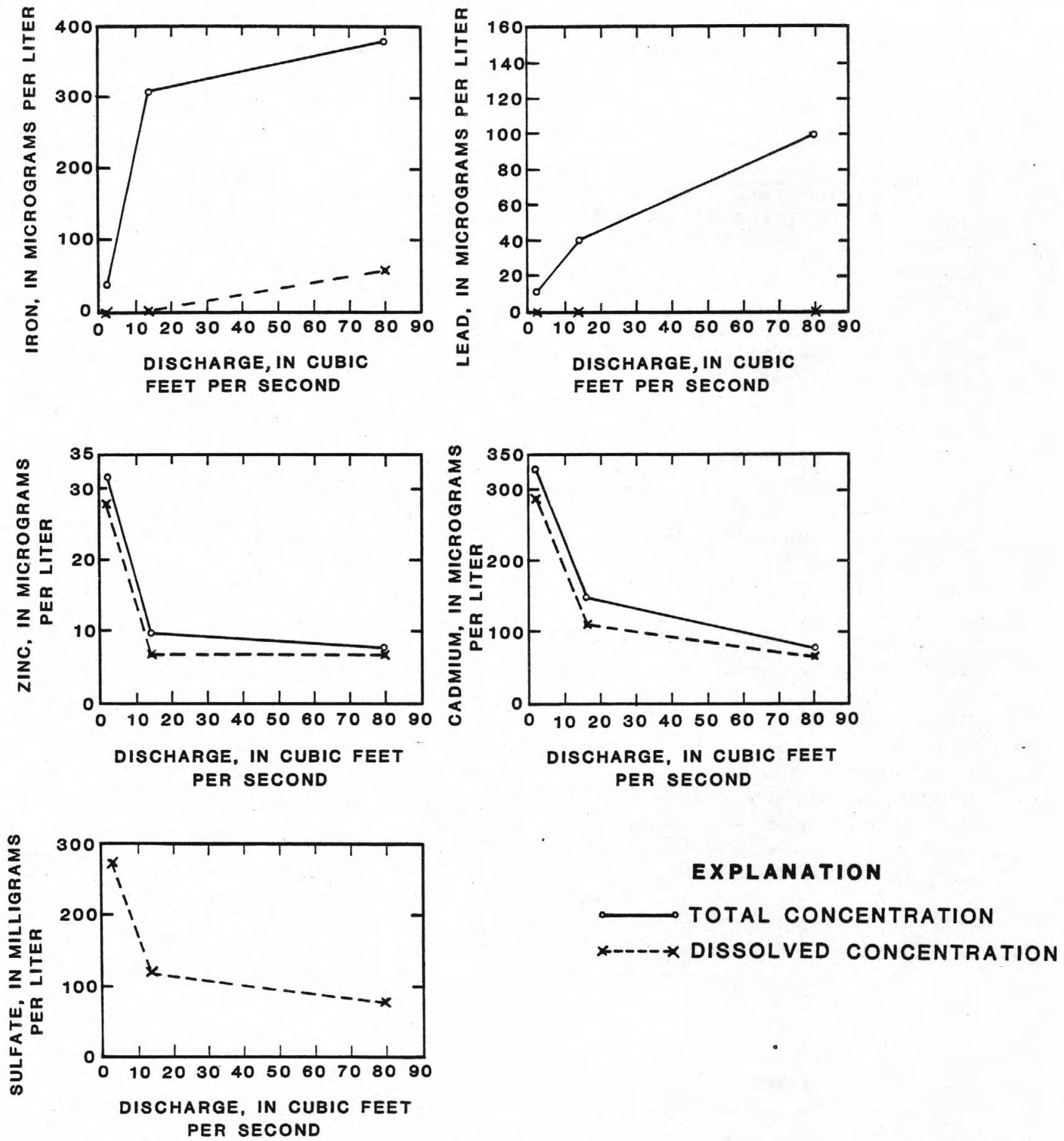

Figure 21.--Relationship of total and dissolved concentrations of selected chemical constituents to discharge in water from Short Creek at Galena, 1981-82.

Survey, 1976-79) indicated extremely large concentrations of sulfate (740 $\mathrm{mg} / \mathrm{L})$, zinc $(200,000 \mu \mathrm{g} / \mathrm{L})$, cadmium $(900 \mu \mathrm{g} / \mathrm{L})$, copper $(6,700 \mu \mathrm{g} / \mathrm{L})$, manganese $(3,500 \mu \mathrm{g} / \mathrm{L})$, fluoride $(6 \mathrm{mg} / \mathrm{L})$, and phosphorus $(100 \mathrm{mg} / \mathrm{L})$. Concentrations that occurred before 1979 were much larger than could be 
accounted for due to discharge from just the mines. Barks (1977, p. 33) indicated that effluent, which was discharged onto a large gypsum pile from a fertilizer plant in Missouri, was acidic, contained large concentrations of metals, and probably caused the extreme concentrations of constituents observed in Short Creek. Such discharges from the fertilizer plant apparently did not occur during the times that Short Creek was sampled during low-flow conditions for this study (August 1981 and March 1982), as dissolved concentrations of sulfate and trace metals, with the exception of manganese, in Short Creek were generally equal to or smaller than concentrations observed in the mines.

Stream biota are severely affected by concentrations of certain trace metals. Cadmium and zinc are known to be highly toxic to many freshwater organisms (U.S. Environmental Protection Agency, 1976a). No benthic invertebrates were found in the samples collected at sites 16 and 18 (fig. 4), indicating severe toxic effects, probably due to the occurrence of large concentrations of cadmium, zinc, and other trace metals.

Effects of Short Creek on the Spring River may be evaluated from analyses of six sampling sites along the Spring River from Waco, Missouri, to Baxter Springs, Kansas (fig. 4). Changes in selected chemical constituents from the upstream, or minimally affected site (site 1) to the most downstream, or maximally affected sites, are shown in figure 22. From this diagram, the major effects appear to be increases in zinc, manganese, and sulfate in Empire Lake (an impounded 4- to 5-mile reach of the Spring River upstream from Riverton, Kansas, fig. 4, site 5). Analyses from the Spring River at Baxter Springs downstream from Empire Lake (site 6) are lower in these constituents, indicating either transformations of chemical compounds within the lake or more likely, dilution by Shoal Creek, which enters Empire Lake near a low-head dam at Riverton, Kansas. This is suggested by the large increase in discharge at Baxter Springs below the lake. Two other major tributaries, Brush Creek and Willow Creek, are located between the dam and Baxter Springs, although Brush Creek was not flowing and Willow Creek contributed insignificant streamflow (less than $0.3 \mathrm{ft}^{3} / \mathrm{s}$ ) to the Spring River.

At low flow, zinc, manganese, and sulfate are major dissolved contaminants to the Spring River from lead-zinc mines, although most trace metals derived from Short Creek either precipitate on reaching the Spring River as a result of an increase in $\mathrm{pH}$ and the presence of bicarbonate ion or are diluted by the Spring River. However, during August 1981, zinc remained in solution in Empire Lake at concentrations of more than $400 \mu \mathrm{g} / \mathrm{L}$ and manganese at concentrations of more than $200 \mu \mathrm{g} / \mathrm{L}$ (fig. 22, site 5). Lead, also a contaminant associated with the lead-zinc mines, is transported to the Spring River from Short Creek, primarily in the form of suspended material or sediment during periods of high flow, as suggested in figure 21. Reduced biological diversity observed by the Kansas Department of Health and Environment (1980) in the Spring River at site 6 (fig. 22) was attributed to large zinc concentrations but also could be due to mobilization of several toxic trace metals associated with the sediment. 

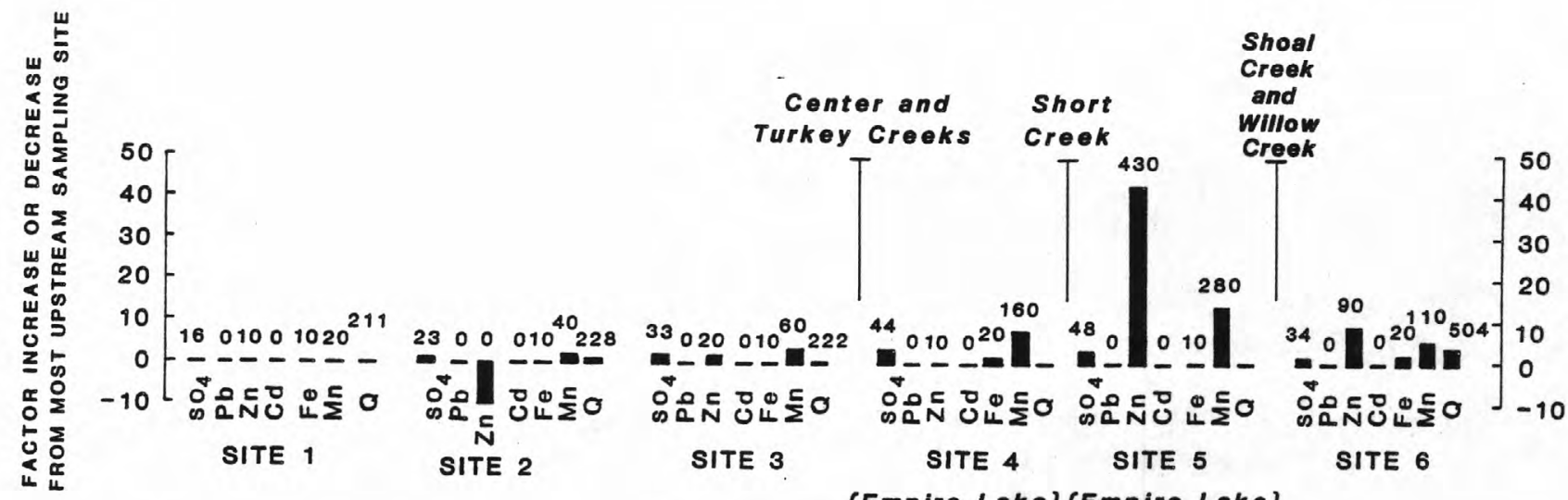

(Empire Lake) (Empire Lake)

\section{EXPLANATION}

16 NUMBER AT TOP OF BAR INDICATES OBSERVED CONCENTRATION IN MILLIGRAMS PER LITER FOR DISSOLVED SULFATE $\left(\mathrm{SO}_{4}\right)$, AND IN MICROGRAMS PER LITER FOR DISSOLVED LEAD (Ph), ZINC ( $Z$ n), CADMIUM (Cd), IRON (FQ). AND MANGANESE (Mn). DISCHARGE (Q) IS GIVEN IN CUBIC FEET PER SECOND INDICATES THAT TRIBUTARY ENTERS BETWEEN THE UPSTREAM AND DOWNSTREAM SAMPLING SITES

Figure 22.--Downstream changes in concentrations of selected chemical constituents in water from six sampling sites on Spring River, August 1981.

Effects of abandoned mines on Tar Creek and Willow Creek in the western area are more difficult to evaluate because there are fewer data available. Because both of these streams do not naturally flow during dry periods, comparison of upstream versus downstream reaches may be made only during or just after relatively wet periods. Because no discharging drill holes were observed in the western area in Kansas during this study, it appears that the principal effects of abandoned lead and zinc mines on surface-water quality in Tar and Willow Creeks are associated with drainage from chat piles. However, short-term discharges of mine-contaminated. ground water from drill holes or fractures that have been reported could affect surfacewater quality. Also, as noted previously, a westward shift of the 800-foot potentiometric contour (fig. 9) could possibly cause ground-water discharges from drill holes and could affect surface-water quality in the vicinity of Baxter Springs, Kansas, in the future.

Although more data would be necessary for confirmation, effects of mine drainage on low-flow concentrations of most chemical constituents in willow Creek appear to be minimal. Willow Creek upstream of the lead-zinc mine areas was dry during August 1981. Seepage from chat and soils, and drainage of water used to wash gravel (site 23, fig. 4, table 23) contribute some base flow to Willow Creek downstream from the mined area. However, ponded areas of the stream were observed during August 1981, so that flow was not continuous through the entire stream channel. Water samples collected from three sites downstream from the mined area (sites 24, 25, and 26, fig. 4, table 23 at the end of this report) during $10 w-f 10 w$ conditions in August 1981, contained $37-41 \mathrm{mg} / \mathrm{L}$ of dissolved sulfate, $170-250 \mu \mathrm{g} / \mathrm{L}$ of dissolved iron, 40-170 $\mu \mathrm{g} / \mathrm{L}$ of dissolved manganese, less than $10 \mu \mathrm{g} / \mathrm{L}$ of dissolved cadmium, $10 \mu \mathrm{g} / \mathrm{L}$ of dissolved lead, 140-180 $\mathrm{\mu g} / \mathrm{L}$ of dissolved zinc, and exhibited specific conductances ranging between 130-200 micromhos per centimeter at $25^{\circ}$ Celsius (micromhos). Concentrations of these constituents were at or below the median concentrations for chemical constituents shown for five streams in the western area (table 14). 
Seepage from chat appears to have the most pronounced effect on water quality in Willow Creek during and just after rainfall. A sample obtained after a rain during March 1982, from a small unnamed tributary of Willow Creek (site 22, fig. 4, table 23), which receives drainage from chat piles, contained large concentrations of cadmium $(110 \mu \mathrm{g} / \mathrm{L})$ and zinc $(13,600 \mu \mathrm{g} / \mathrm{L})$. The moderate alkalinity $(46 \mathrm{mg} / \mathrm{L})$ and $\mathrm{pH}$ of 7.3 indicate the presence of 1 imestone in the chat. Comparison of sulfate and trace-metal concentrations at upstream (site 27, table 23) and downstream (site 24, table 23) sampling sites on Willow Creek sampled during June 1981 shows that an increase in zinc from 180 to $620 \mu \mathrm{g} / \mathrm{L}$ was the major noticable effect of drainage from chat piles.

Because more than 10 percent of the Tar Creek basin in Kansas is covered by extensive chat piles (compared to approximately 1 percent in the Willow Creek basin), effects of abandoned lead-zinc mines on Tar Creek are more pronounced than in Willow Creek. A sample obtained from a stream draining a chat pile in the Tar Creek basin (site 32, table 23 at the end of this report) exhibited large concentrations of dissolved zinc $(5,800$ $\mu \mathrm{g} / \mathrm{L})$ and cadmium $(57 \mu \mathrm{g} / \mathrm{L})$. The relatively high $\mathrm{pH}$ of this water $(7.4)$ along with the high alkalinity $(130 \mathrm{mg} / \mathrm{L})$ reflects substantial quantities of limestone in the chat, which may limit lead, iron, and manganese solubility. A low-flow sample collected from Tar Creek near Treece, Kansas (site 28, table 23 at the end of this report), contained maximum concentrations of sulfate $(910 \mathrm{mg} / \mathrm{L})$, zinc $(5,800 \mu \mathrm{g} / \mathrm{L})$, and cadmium $(40 \mu \mathrm{g} / \mathrm{L})$ compared with low-flow samples collected from four other major streams in the western area in Kansas (sites 26, 33, 34, and 37, fig. 4; U.S. Geological Survey, 1976-79).

Effects of drainage from chat piles on stream-water quality in Tar Creek may be observed by comparison of upstream and downstream sampling sites during a high-flow period during June 1981 and a low-flow period during August 1981 (fig. 23). The upstream sampling site (site 29) during August actually received drainage from chat piles, but no flow was observed at sites upstream from the mined area during August. During both 10 w and high flows, the principal changes in water quality from upstream to downstream sites were increased concentrations of dissolved sulfate, cadmium, and zinc. These changes are due primarily to drainage from the chat because, as previously indicated, very little base flow is derived from the shales. Concentrations of dissolved manganese, iron, and lead are relatively unaffected or even decrease in concentration. Iron and manganese concentrations at the upstream sampling site (site 30) for high-flow conditions may be due partially to the abundant decaying leaves from trees lining the streambank at this site; the sample from the upstream site was obtained below a ponded part of the stream that contained dark-brown colored water, suggestive of organic acids. No chat piles were present near the upstream site.

Minimum, median, and maximum concentrations and values of selected chemical constituents in samples obtained at low and medium flows in Tar Creek near Treece, Kansas, are given in table 15. These data show that concentrations of sulfate, zinc, and cadmium are largest at low flow and indicate that these chemical constitutents are derived from chat seepage. If chat piles in the basin are removed in the future, this should result in smaller concentrations of sulfate zinc, and cadmium in Tar Creek. 
Total iron, manganese, lead, and copper concentrations are largest during high flows. These constituents are primarily transported in the suspended form. Lead may be derived primarily from particulate material from chat piles. Iron, manganese, and copper may originate from residual soils and vegetation, as well as from the chat.

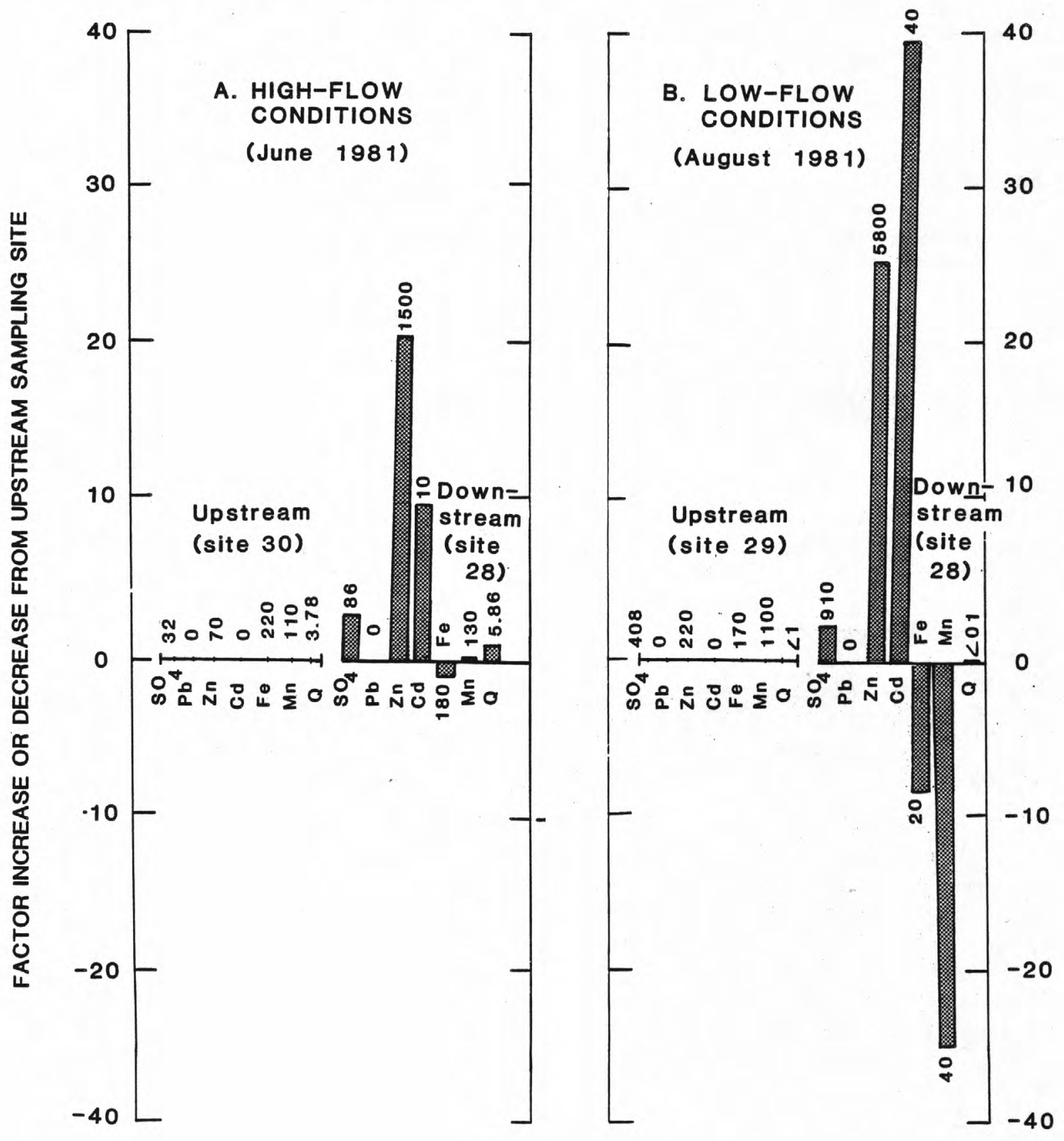

EXPLANATION

408 NUMBER AT TOP OF BAR INDICATES OBSERVED CONCENTRATION IN MILLIGRAMS PER LITER FOR SULFATE $\left(\mathrm{SO}_{4}\right)$ AND IN MICROGRAMS PER LITER FOR DISSOLVED LEAD (Pb), ZINC ( $\mathrm{n}$ ), CADMIUM (Cd), IRON ( $\mathrm{Fe}$ ), AND MANGANESE $(\mathrm{Mn})$. DISCHARGE $(Q)$ IS GIVEN IN CUBIC FEET PER SECOND

Figure 23.--Downstream changes in concentrations of selected chemical constituents at two sampling sites on Tar Creek, June and August 1981. 
Table 15.--Minimum, median, and maximum concentrations of selected chemical constituents observed in samples obtained at low and medium flows from Tar Creek, 1976-82

[Values are given in milligrams per liter $(\mathrm{mg} / \mathrm{L})$ and micrograms per liter $\mathrm{ug} / \mathrm{L})]$

\begin{tabular}{|c|c|c|c|c|c|c|c|c|c|}
\hline $\begin{array}{l}\text { Chemical } \\
\text { constituent }\end{array}$ & $\begin{array}{l}\text { Unit } \\
\text { of } \\
\text { meas }\end{array}$ & (1ess $t$ & $\begin{array}{r}\text { Low flo } \\
\text { than } 2 \mathrm{cu} \\
\text { second }\end{array}$ & i) & $t$ per & (2 to 1 & $\begin{array}{l}\text { dium } f \\
\text { cubic } \\
\text { econd) }\end{array}$ & $\begin{array}{l}\text { low } \\
\text { feet per }\end{array}$ & \\
\hline & $\begin{array}{l}\text { ure- } \\
\text { ment }\end{array}$ & Minimum & m Median & Maximum & $\begin{array}{l}\text { Num- } \\
\text { ber } \\
\text { of } \\
\text { sam- } \\
\text { ples }\end{array}$ & Minimum & Median & Maximum & $\begin{array}{l}\text { Num- } \\
\text { ber } \\
\text { of } \\
\text { sam- } \\
\text { ples }\end{array}$ \\
\hline Sulfate & $(\mathrm{mg} / \mathrm{L})$ & 912 & 960 & 1,400 & 3 & 86 & 97 & 250 & 3 \\
\hline Total cadmium & $(\mu \mathrm{g} / \mathrm{L})$ & & & & 3 & 10 & 20 & 30 & 3 \\
\hline Total zinc & $(\mu \mathrm{g} / \mathrm{L})$ & 6,200 & 8,800 & 12,000 & 3 & 1,600 & 1,900 & 7,400 & 3 \\
\hline Total lead & $(\mu \mathrm{g} / \mathrm{L})$ & 0 & 10 & 60 & 3 & 50 & 100 & 100 & 3 \\
\hline $\begin{array}{l}\text { Total man- } \\
\text { ganese }\end{array}$ & $(\mu \mathrm{g} / \mathrm{L})$ & 50 & 160 & 280 & 3 & 140 & 210 & 380 & 3 \\
\hline Total cop- & $(\mu \mathrm{g} / \mathrm{L})$ & 0 & 10 & 10 & 3 & 0 & 20 & 50 & 3 \\
\hline $\begin{array}{l}\text { per } \\
\text { Total iron }\end{array}$ & $(\mu \mathrm{g} / \mathrm{L})$ & 100 & 170 & 270 & 3 & 540 & 730 & 730 & 3 \\
\hline
\end{tabular}

Generally, zinc and cadmium, which occur in Tar Creek in Kansas, are the two chemical constituents having potentially the greatest effect on health or aquatic life. The occurrence of zinc and cadmium in Tar Creek, as well as extreme sulfate concentrations, is due primarily to chat drainage. Even though concentrations of cadmium now occur at concentrations above the drinking-water standard $(10 \mu \mathrm{g} / \mathrm{L})$ and suggested aquatic-life standards $\left[12 \mu \mathrm{g} / \mathrm{L}\right.$ for cadmium in hard water $\left.\left(150-300 \mathrm{mg} / \mathrm{L}, \mathrm{CaCO}_{3}\right)\right]$ and zinc [approximately $250 \mathrm{\mu g} / \mathrm{L}$ for Pimaphales promelas (Fathead minnow)] (U.S. Environmental Protection Agency, 1976a), these waters are used for fishing by local residents. Although no benthic invertebrate samples were obtained, the author observed larval forms of Odonata and Coleoptera, as well as Hemipteran Corixidae and Notonectidae and Dipteran Chironomidae, indicating the presence of some members of biological communities typical for streams of this area.

The relatively large values for hardness (due to calcium and magnesium ions) and alkalinity of waters in Tar Creek in Kansas may mitigate possible toxic effects of cadmium and zinc on the aquatic life in these waters. Although the specific mechanism is not known, reduction in toxicity may be due either to formation of metallic hydroxides and carbonates or because of some antagonistic effect of one of the principal cations contributing to hardness (U.S. Environmental Protection Agency, 1976a, p. 76). 
A study was conducted to evaluate water-resources problems related to abandoned lead and zinc mines in Cherokee County, Kansas, and adjacent areas in Missouri and 0klahoma.

The principal effects of abandoned lead and zinc mines on ground- and surface-water hydrology, and on ground- and surface-water quality are outlined below:

\section{Ground-water hydrology}

A. Past-mining activities have caused discontinuities and perforations in confining shales west of the Pennsylvanian-Mississippian geologic contact, which in turn have created artificial recharge and discharge areas. Recharge to the shallow aquifer through collapses and drill holes in the shales has caused formation of a ground-water "mound" in the vicinity of the Picher Field in OKlahoma and Kansas. Discharge of mine-contaminated ground water to Tar Creek occurs in Oklahoma from drill holes where the potentiometric surface of the shallow aquifer is above the 1 and surface. Continuous discharges are not likely to occur in the Tar Creek basin in Kansas but could occur in the Willow Creek basin near Baxter Springs, Kansas.

B. The presence of abandoned wells and drill holes in the area allows the possibility of downward movement of water from the shallow to the deep aquifer. Because of the tremendous volume of water that could be transported downward, open drill holes or well casings present the greatest contamination hazard to water supplies in the deep aquifer.

C. Mining in the shallow aquifer has resulted in extensive fracturing and removal of material, which create highly transmissive zones and increase ground-water storage properties of the aquifer. In the eastern area, fractured rock and tailings increased the amount of water available for infiltration to the shallow aquifer; in the western area, tailings on the impermeable shales created artificially perched aquifer systems that drain to surface streams.

D. Development of mining in the area resulted in extensive pumping of the deep aquifer, which lowered the potentiometric surface of the deep aquifer below that of the shallow, causing a potential for downward movement of water over a large area. The potential is greatest in Ottawa County, Oklahoma.

\section{Surface-water hydrology}

Major effects of abandoned mines on surface-water hydrology are: (1) Increased base flow in streams due to increased ground-water storage in fractured porous material in chat on the land surface and in voids created in the mines in the eastern area and increased base flow in streams due to seepage from chat on the land surface in the western area, (2) increased base flow in Tar Creek in 
Oklahoma due to discharge of ground water from the shallow aquifer through abandoned drill holes and shafts, and (3) reduction of the amount of water that moves through stream channels in the Tar Creek basin in the western area downstream from areas where the stream channel has subsided or where drill holes or shafts are present on the flood plain or streambed.

\section{Ground-water quality}

A. Mining allowed oxidation of ore deposits, which, on resaturation with water, resulted in poor-quality water that is generally high in sulfate and trace-metal content. Water from abandoned mines in the eastern area exhibited dissolved-solids concentrations of less than $500 \mathrm{mg} / \mathrm{L}$, a median $\mathrm{pH}$ of 3.9 , sulfate concentrations that ranged between 98 and $290 \mathrm{mg} / \mathrm{L}$, and median concentrations of zinc $(37,600$ $\mu \mathrm{g} / \mathrm{L})$, lead $(240 \mu \mathrm{g} / \mathrm{L})$, cadmium $(180 \mu \mathrm{g} / \mathrm{L})$, iron $(70 \mu \mathrm{g} / \mathrm{L})$, manganese $(240 \mu \mathrm{g} / \mathrm{L})$, and silica $(15 \mathrm{mg} / \mathrm{L})$. Water quality in these mines is not likely to change significantly with time. Water from mines in the western area generally exhibited dissolved-solids concentrations of more than $500 \mathrm{mg} / \mathrm{L}$, a median $\mathrm{pH}$ of 6.8 , sulfate concentrations that ranged between 170 and $2,150 \mathrm{mg} / \mathrm{L}$, and median concentrations of zinc $(3,200 \mu \mathrm{g} / \mathrm{L})$, lead $(0 \mu \mathrm{g} / \mathrm{L})$, cadmium $\left(6^{\circ} \mu \mathrm{g} / \mathrm{L}\right)$, iron $(840 \mu \mathrm{g} / \mathrm{L})$, manganese $(440 \mu \mathrm{g} / \mathrm{L})$, and silica $(11 \mathrm{mg} / \mathrm{L})$.

Generally, the largest values of specific conductance and concentrations of sulfate, silica, iron, zinc, and cadmium were observed in the lower mine levels. Data from one mine in Oklahoma indicate that decreases in zinc, cadmium, and lead have occurred with no change in iron or sulfate concentrations. Inflow of ground water containing the sulfide ion from reducing zones of the shallow aquifer may account for the decrease in zinc, cadmium, and lead under conditions of $10 \mathrm{w} \mathrm{pH}$. Iron and manganese may persist in the mines unless enough bicarbonate and carbonate ions are introduced into the mines in quantities sufficient to neutralize the acidity produced by oxidation of pyrite and marcasite.

B. No conclusive evidence of lateral migration of water from the mines into domestic well-water supplies in the shallow aquifer was found in the study area in Kansas. East of the Pennsylvanian-Mississippian contact, well waters away from the mined areas ranged from a calcium bicarbonate type to a calcium magnesium sulfate bicarbonate type near the contact. Water west of the contact is characterized by a sodium bicarbonate or calcium sodium bicarbonate chloride type accompanied by the presence of hydrogen sulfide.

C. Analyses of water from public-supply wells tapping the deep aquifer did not indicate contamination with trace metals, although trend analysis conducted on sulfate concentrations in six deep watersupply wells indicated significant increases in four of the wells tested. However, no wells exceeded the recommended maximum sulfate concentration of $250 \mathrm{mg} / \mathrm{L}$. These increases probably reflect localized leakage of water from the shallow aquifer along leaky well casings. 


\section{Surface-water quality}

A. The effects of abandoned mines on tributaries east of the Spring River are most severe in Short Creek, which exhibited the lowest $\mathrm{pH}$ (6.0) and largest dissolved concentrations of sulfate $(240 \mathrm{mg} / \mathrm{L})$, zinc $(25,000 \mu \mathrm{g} / \mathrm{L})$, cadmi um $(170 \mu \mathrm{g} / \mathrm{L})$, and manganese $(1,700 \mu \mathrm{g} / \mathrm{L})$, compared with sample analyses from three other major streams in the eastern area. Concentrations of these constituents are due primarily to inflow of ground water from the breccia, mines, and seepage from chat piles in the Short Creek basin. The large concentrations of zinc and cadmium probably have caused the complete absence of benthic invertebrates in stream water from Galena to the Spring River. Suspended lead and iron concentrations increased with discharge in Short Creek.

B. Increased dissolved-zinc and -manganese concentrations were observed in the Spring River below Short Creek. These larger concentrations may contribute to decreased biological diversity below Short Creek. Mobilization of adsorbed trace metals on sediment from Short Creek also might account for the decrease in biological diversity.

C. In the western area, drainage from tailings, which act as perched aquifers on impervious Pennsylvanian shales, appeared to have little effect on water quality in Willow Creek during low-flow conditions but caused larger concentrations of dissolved zinc just after a wet period during June 1981. Drainage from tailings caused large concentrations of sulfate, zinc, and cadmium in Tar Creek in Kansas. Compared with four other major streams in the western area, Tar Creek contained maximum low-flow concentrations of sulfate (910 $\mathrm{mg} / \mathrm{L})$, zinc $(5,800 \mu \mathrm{g} / \mathrm{L})$, and cadmium $(40 \mu \mathrm{g} / \mathrm{L})$.

\section{SELECTED REFERENCES}

Abernathy, G. E., 1943, Deep water well at the Jayhawk Ordnance Works in Cherokee County, Kansas: Kansas Geological Survey Bulletin 47, part 3, p. 77-112.

American Public Health Association, 1975, Standard methods for the analysis of water and wastewater (14th ed.): American Public Health Association, $1142 \mathrm{p}$.

Bailey, E. H. S., 1911, Preliminary report on stream pollution by mine waters in southeastern Kansas: U.S. Geological Survey Water-Supply Paper 273, p. 349-361.

Barks, J. H., 1977, Effects of abandoned lead and zinc mines and tailings piles on water quality in the Joplin area, Missouri: U.S. Geological Survey Water-Resources Investigations 77-75, $55 \mathrm{p}$. 
Brichta, L. C., 1960, Catalog of recorded exploration drilling and mine workings Tri-State zinc-lead district--Missouri, Kansas, and Oklahoma: U.S. Bureau of Mines Information Circular 7993, $13 \mathrm{p}$.

Brown, Eugene, Skougstad, M. W., and Fishman, M. J., 1970, Methods for collection and analysis of water samples for dissolved minerals and gases: U.S. Geological Survey Techniques of Water-Resources Investigations, Book 5, Chapter A1, $160 \mathrm{p}$.

Conover, W. J., 1971, Practical nonparametric statistics: New York, John Wiley \& Sons, Inc., 462 p.

Feder, G. L., Shelton, John, Jeffery, H. G., and Harvey, E. J., 1969, Water resources of the Joplin area, Mo.: Missouri Geological Survey and Water Resources, Water Resources Report 24, $97 \mathrm{p}$.

Frye, J. C., and Schoewe, W. H., 1953, The basis for physiographic subdivision of Kansas: Transactions of the Kansas Academy of Sciences, v. 56 , no. 2 , p. $246-252$.

Gann, E. E., Harvey, E. J., Barks, J. H., Fuller, D. L., and Miller, D. E., 1974, Water resources of west-central Missouri: U.S. Geological Survey Hydrologic Investigations Atlas HA-491, 4 sheets.

Harvey, E. J., and Emmett, L. F., 1980, Hydrology and model study of the proposed Prosperity reservoir, Center Creek basin, southwestern Missouri: U.S. Geological Survey Water-Resources Investigations 80-7, 50 p.

Havens, J. S., 1978, Ground-water records for eastern Oklahoma, part 2-Water-quality records for wells, test-holes, and springs: U.S. Geological Survey Open-File Report 78-357, 130 p.

Haworth, Erasmus, 1904, Lead and zinc: Lawrence, Kansas, University of Kansas Special Report, v. 8, 509 p.

Hittmann Associates, 1981, Interim report--Surface and ground water contamination from abandoned lead-zinc mines Picher Mining District, Ottawa County, Ok1 ahoma: H-D8034-001-81-1042, 37 p.

Kansas Department of Health and Environment, 1980, Water quality investigations of lead-zinc mine drainage effects on Spring River and associated tributaries in Kansas, 1978-1979: Water Quality Management Section, Kansas Department of Health and Environment, $42 \mathrm{p}$.

Kinney, E. D., 1941, Treatment of mine water as a factor in the mineral production in southeastern Kansas: Kansas Geological Survey Bulletin 38, 1941 Reports of Studies, No. 1, p. 1-16.

Klugh, H. E., 1970, Statistics--The essentials for research: New York, John Wiley \& Sons, Inc., 368 p. 
Krauskopf, K. B., 1967, Introduction to geochemistry: New York, McGraw-Hil1 Book Co., $721 \mathrm{p}$.

Lohman, S. W., 1979, Ground-water hydraulics: U.S. Geological Survey Professional Paper 708, 70 p.

Manger, G. E., 1963, Porosity and bulk density of sedimentary rocks: U.S. Geological Survey Bulletin 1144-E, 55 p.

Marcher, M. V., Kenny, J. F., and others, 1983, Hydrology of Area 40, Western Region, Interior Coal Province, Kansas, Oklahoma, and Missouri: U.S. Geological Water-Resources Investigations Report 83-2661 (in press).

Martin, A. J., 1946, Summarized statistics of production of lead and zinc in the Tri-State (Missouri-Kansas-0klahoma) mining district: U.S. Bureau of Mines Information Circular 7383; $67 \mathrm{p}$.

McCauley, J. R., Brady, L. L., and Wilson, F. W., 1983, Study of stability problems and hazard evaluation of the Kansas portion of the Tri-State mining area: U.S. Bureau of Mines Mining Research Contract Report, $193 \mathrm{p}$.

MacFarlane, P. A., Whittemore, D. 0., and Hathaway, L. R., 1981, A report to the Kansas Department of Health and Environment on the hydrogeology and chemical quality in lower Paleozoic aquifers in southeast Kansas and adjoining areas of Missouri and Oklahoma: Kansas Geological Survey Open-File Report 81-16, 48 p.

Mcknight, E. T., and Fischer, R. P., 1970, Geology and ore deposits of the Picher field, OKlahoma and Kansas. U.S. Geological Survey Professional Paper 588, $165 \mathrm{p}$.

Meyer, R. R., 1963, A chart relating well diameter, specific capacity, and the coefficients of transmissability and storage, in Methods of determining permeability, transmissability, and drawdown: U.S. Geological Survey Water-Supply Paper 1536-I, p. 243-341.

Oklahoma Water Resources Board, 1981, Summary of data collected by Governor's Tar creek task force regarding ground-water discharge from abandoned lead and zinc mines of Ottawa County, Oklahoma, December 1979 to March 1981: Oklahoma Water Resources Board, 40 p.

Playton, S. J., Davis, R. E., and MCClaflin, R. G., 1978, Chemical quality of water in abandoned zinc mines in northeastern $0 \mathrm{kl}$ ahoma and southeastern Kansas: U.S. Geological Survey Open-File Report 78-294, 59 p.

Reed, E. W., Schoff, S. L., and Branson, C. C., 1955, Ground-water resources of Ottawa County, Oklahoma: Oklahoma Geological Survey Bulletin 72, 203 p.

Robertson, C. E., 1963, Well data for water well yield map, in Groundwater maps of Missouri: Missouri Division of Geological Survey and Water Resources, 4 sheets. 
Siebenthal, C. E., 1915, Origin of the zinc and lead deposits of the Joplin region, Missouri, Kansas, and OKTahoma: U.S. Geological Survey BuTletin $606,283 \mathrm{p}$.

Stramel, G. J., 1957, The hydraulic properties of the Ordovician rocks at Pittsburg, Kansas: Kansas Geological Survey Bulletin 127, 1957 Reports of Studies, pt. 5, p. 153-178.

Stumm, Werner, and Morgan, J. J., 1970, Aquatic chemistry--An introduction emphasizing chemical equilibria in natural waters: New York, John Wiley \& Sons, Inc., 583 p.

U.S. Bureau of Mines, 1946-70, Mineral industry of Kansas and mineral industry of Oklahoma, in Minerals yearbook: Washington, D.C., U.S. Government Printing office (published annualiy).

U.S. Environmental Protection Agency, 1976a, Quality criteria for water: U.S. Environmental Protection Agency, $256 \mathrm{p}$.

1976b, National interim primary drinking water regulations: EPA-570/976-003, $159 \mathrm{p}$.

1977, Proposed interim secondary drinking water regulations: Federal Register, v. 42, no. 62, p. 17143-17146.

U.S. Geological Survey, 197.6-79, Water resources data for Kansas, water years 1976-79: U.S. Geological Survey Water Data Reports KS-76-1 through KS-79-1,2 (published annually).

U.S. Soil Conservation Service, 1972, Resource conservation and development plan, southeast Kansas: U.S. Department of Agriculture, Soil Conservation Service, 209 p.

U.S. Soil Conservation Service and Kansas Water Resources Board, 1980, Southeast Kansas water supply study: U.S. Soil Conservation Service and Kansas Water Board Plans of Regional Water Supply Systems, 209 p.

Walker, E. H., 1956, Ground-water resources of the Hopkinsville quadrangle, Kentucky: U.S. Geological Survey Water-Supply Paper 1328, 98 p.

Walton, W. C., 1960, Leaky artesian aquifer conditions in Illinois: I11inois State Water Survey, Report of Investigation 39, $27 \mathrm{p}$.

1970, Groundwater resource evaluation: New York, McGraw-Hill Book Co., 664 p.

Williams, C. C., 1948, Contamination of deep water wells in southeastern Kansas: Kansas Geological Survey Bulletin 76, pt. 2, p. 13-28.

Wood, W. W., 1976, Guidelines for collection and field analysis of groundwater samples for selected unstable constituents: U.S. Geological Survey Techniques of Water-Resources Investigations, Book 1, Chapter D2, 24 p. 
SUPPLEMENTAL INFORMATION 
The following method was used to estimate the volume of water leaking from the shallow to the deep aquifer.

1. A hydraulic-head difference map was constructed for the study area (see figure 11 of this report).

2. Approximate hydraulic-head differences were assigned for eight subareas. The approximation was assigned based on the midpoint between the lower and upper contour value. Areas were computed by using a compensating polar planimeter. The subareas, assigned hydraulic-head differences, and estimated leakage to the deep aquifer are listed below and correspond to subareas shown in the sketched figure.

\section{EXPLANATION}

Map not to scale. Letters refer to subareas shown in the accompanying table.

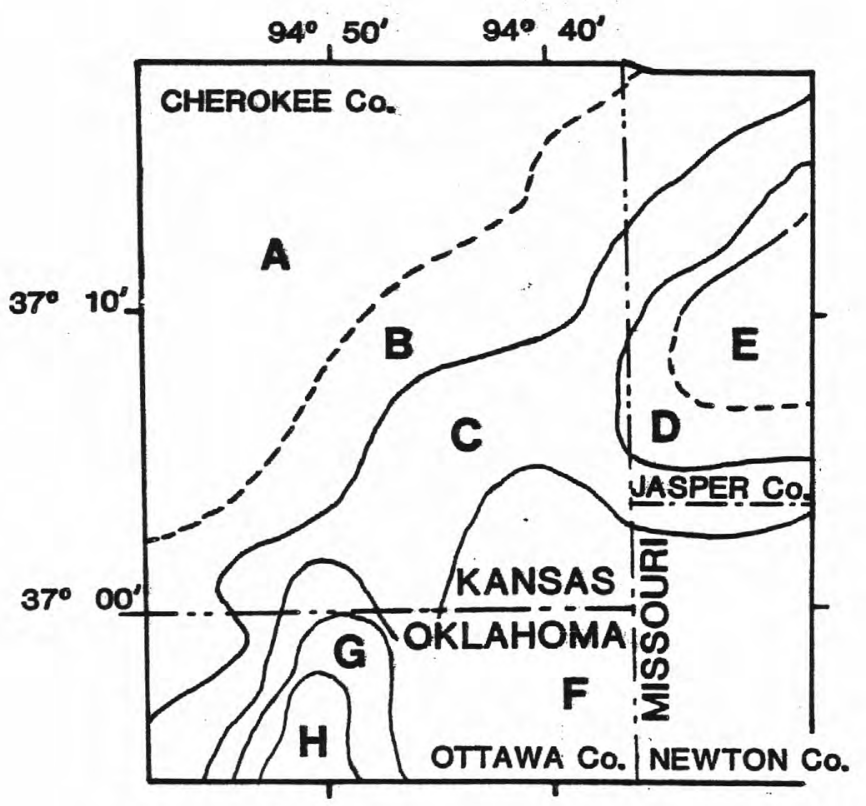




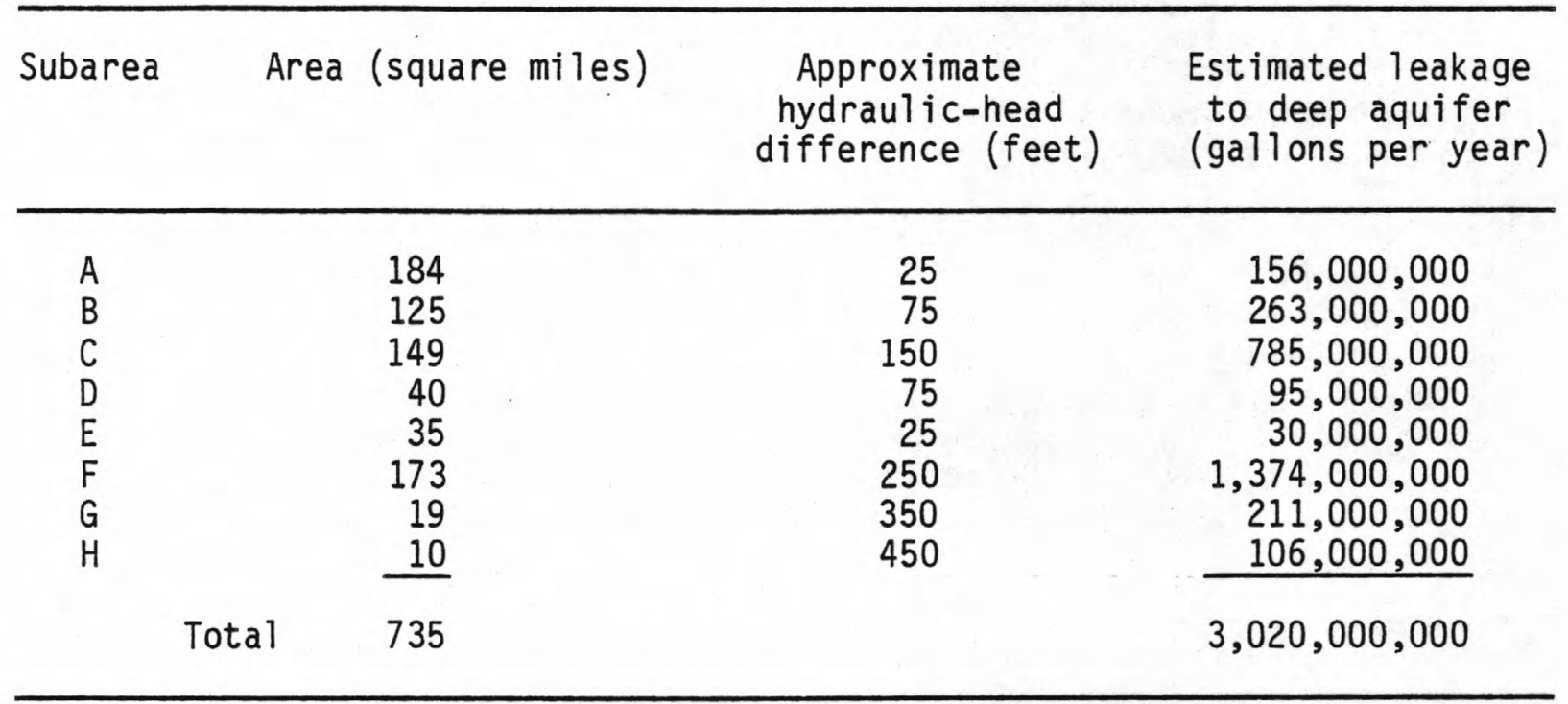

3. Leakage was estimated from the formula presented in Walton (1970, p. 360):

$$
Q_{c}=A_{c}\left(2.9 \times 10^{7}\right) \frac{p^{\prime}}{m^{\prime}} \Delta h,
$$

where $\quad Q_{c}=$ vertical leakage, in gallons per day per square mile;

$A_{c}=$ recharge area within which vertical leakage is being diverted to a pumping center, in square miles;

$p^{\prime}=$ coefficient of permeability of deposits, in gallons per day per square foot;

$\mathrm{m}^{\prime}$ = saturated thickness of deposits through which leakage occurs, in feet; and

$\Delta h=$ hydraulic-head difference, in feet, between upper and lower aquifer. 
Table 16.--Location and information for mines in the shallow aquifer

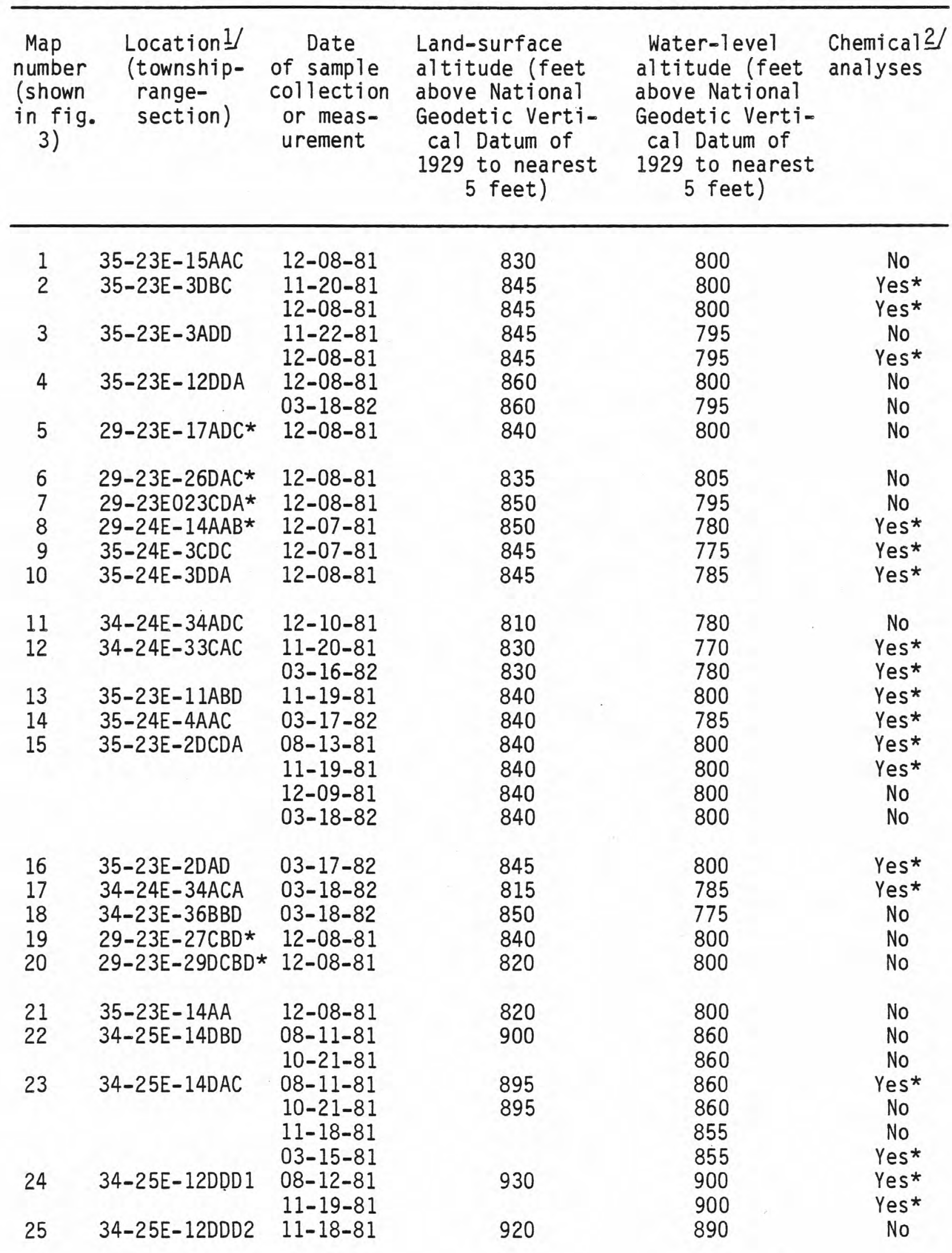


Table 16.-- Location and information for mines in the shallow aquifer-Continued

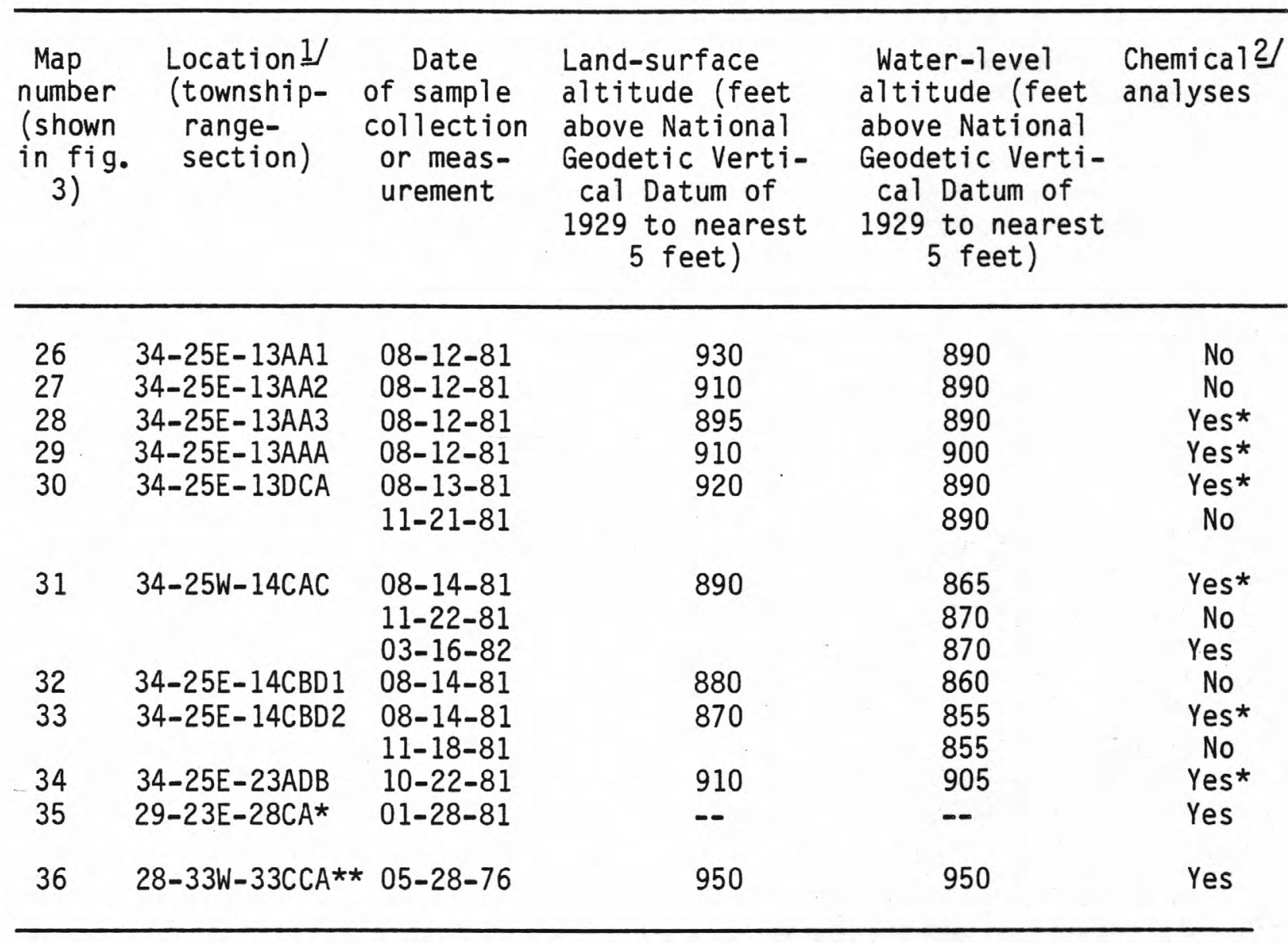

1 Locations in Oklahoma (denoted by one asterisk) and Missouri (denoted by two asterisks) are designated with northern townships; the rest of the locations are in Kansas and are designated with southern townships.

2 Asterisk indicates that analysis is published in this report. 
Table 17.--Location and information for wells in the shallow aquifer [If date for water levels is different than that for water samples, date is given in parenthesis]

\begin{tabular}{|c|c|c|c|c|c|c|c|}
\hline $\begin{array}{l}\text { Map } \\
\text { number } \\
\text { (shown } \\
\text { in fig. } \\
\text { 3) }\end{array}$ & $\begin{array}{l}\text { Location } 1 / \\
\text { (township- } \\
\text { range- } \\
\text { section) }\end{array}$ & $\begin{array}{l}\text { of } \\
\text { col } \\
\text { or }\end{array}$ & $\begin{array}{l}\text { Date } \\
\text { sample } \\
\text { ilection } \\
\text { measure- } \\
\text { ment }\end{array}$ & $\begin{array}{l}\text { Total } \\
\text { well } \\
\text { depth } \\
\text { (feet) }\end{array}$ & $\begin{array}{c}\text { Land-surface } \\
\text { altitude } \\
\text { (feet above } \\
\text { National } \\
\text { Geodetic } \\
\text { Vertical } \\
\text { Datum of } \\
1929 \text { to } \\
\text { nearest } \\
5 \text { feet) }\end{array}$ & $\begin{array}{c}\text { Water-level } \\
\text { altitude } \\
\text { (feet above } \\
\text { National } \\
\text { Geodetic } \\
\text { Vertical } \\
\text { Datum of } \\
1929 \text { to } \\
\text { nearest } \\
5 \text { feet) }\end{array}$ & $\begin{array}{l}\text { Chemical } 2 / \\
\text { analyses }\end{array}$ \\
\hline
\end{tabular}

\begin{tabular}{|c|c|c|c|c|c|c|c|}
\hline $\begin{array}{l}111 \\
112 \\
113 \\
114 \\
115\end{array}$ & $\begin{array}{l}27-34 W-2 B B C * * \\
35-25 E-9 C B A \\
35-25 E-2 C C \\
35-25 E-2 C B B \\
34-25 E-22 B C C\end{array}$ & $\begin{array}{l}08-12-81 \\
03-18-81 \\
07-31-81 \\
07-31-81 \\
07-30-81\end{array}$ & $\begin{array}{r}180 \\
200 \\
180 \\
181 \\
98\end{array}$ & $\begin{array}{l}960 \\
860 \\
950 \\
950 \\
910\end{array}$ & $\begin{array}{l}920 \\
-- \\
920 \\
-- \\
--\end{array}$ & & $\begin{array}{l}\text { Yes* } \\
\text { Yes* } \\
\text { Yes* } \\
\text { Yes* } \\
\text { Yes* }\end{array}$ \\
\hline $\begin{array}{l}116 \\
117 \\
118 \\
119 \\
120\end{array}$ & $\begin{array}{l}34-25 E-21 B A A \\
34-25 E-19 A A B \\
34-25 E 03 D A A \\
32-24 E-35 A A B \\
33-24 E 08 D D A\end{array}$ & $\begin{array}{l}03-16-82 \\
07-31-81 \\
03-16-82 \\
03-18-82 \\
07-31-81\end{array}$ & $\begin{array}{l}160 \\
243 \\
-- \\
347 \\
332\end{array}$ & $\begin{array}{l}900 \\
830 \\
-- \\
900 \\
935\end{array}$ & $\begin{array}{l}820 \\
810 \\
=- \\
-- \\
725\end{array}$ & $(8-21-42)$ & $\begin{array}{l}\text { Yes* } \\
\text { Yes* } \\
\text { Yes* } \\
\text { Yes* } \\
\text { Yes* }\end{array}$ \\
\hline $\begin{array}{l}121 \\
122 \\
123 \\
124 \\
125\end{array}$ & $\begin{array}{l}31-24 E-34 C A \\
32-22 E-1 D D A \\
32-24 E-24 A D \\
32-24 E-27 D D D \\
32-24 E-30 A A A\end{array}$ & $\begin{array}{l}07-09-42 \\
08-27-64 \\
09-09-64 \\
09-08-64 \\
09-09-64\end{array}$ & $\begin{array}{l}520 \\
400 \\
455 \\
400 \\
390\end{array}$ & $\begin{array}{l}920 \\
900 \\
910 \\
900 \\
920\end{array}$ & $\begin{array}{l}730 \\
=- \\
=- \\
-\infty\end{array}$ & & $\begin{array}{l}\text { Yes } \\
\text { Yes } \\
\text { Yes } \\
\text { Yes } \\
\text { Yes }\end{array}$ \\
\hline $\begin{array}{l}126 \\
127 \\
128 \\
129 \\
130\end{array}$ & $\begin{array}{l}32-25 E-36 A D D \\
34-25 E-4 A B D \\
34-24 E-31 C D D \\
29-34 W-14 A A A * * \\
29-33 W-19 C B * *\end{array}$ & $\begin{array}{l}11-08-63 \\
01-19-42 \\
09-04-42 \\
06-13-65 \\
06-11-65\end{array}$ & $\begin{array}{l}230 \\
244 \\
444 \\
300 \\
--\end{array}$ & $\begin{array}{l}910 \\
854 \\
894 \\
\cdot-- \\
855\end{array}$ & $\begin{array}{l}-- \\
-- \\
-- \\
-\infty \\
855\end{array}$ & $(09-76)$ & $\begin{array}{l}\text { Yes } \\
\text { Yes } \\
\text { Yes } \\
\text { Yes } \\
\text { Yes }\end{array}$ \\
\hline $\begin{array}{l}131 \\
132 \\
133 \\
134 \\
135\end{array}$ & $\begin{array}{l}28-34 W-2 A D D * * \\
28-34 W-24 B B B * * \\
28-33 W-23 A B * * \\
28-34 W-36 C A D * * \\
27-34 W-13 C B * *\end{array}$ & $\begin{array}{l}06-11-65 \\
06-10-65 \\
06-10-65 \\
06-11-65 \\
06-09-65\end{array}$ & $\begin{array}{l}210 \\
337\end{array}$ & $\begin{array}{r}870 \\
868 \\
965 \\
1,000 \\
--\end{array}$ & $\begin{array}{l}-- \\
865 \\
920 \\
=- \\
--\end{array}$ & $\begin{array}{l}(09-76) \\
(09-76)\end{array}$ & $\begin{array}{l}\text { Yes } \\
\text { Yes } \\
\text { Yes } \\
\text { Yes } \\
\text { Yes }\end{array}$ \\
\hline $\begin{array}{l}136 \\
137 \\
138 \\
139 \\
140\end{array}$ & $\begin{array}{l}26-33 W-5 B C D * \star \\
26-33 W-23 B A A * \star \\
28-24 E-12 C D * \star \\
29-33 W-2 C D C * \star \\
29-34 W-13 A B B * \star\end{array}$ & $\begin{array}{l}06-08-65 \\
06-09-65 \\
04-27-48 \\
07-27-65 \\
04-23-65\end{array}$ & $\begin{array}{r}-- \\
185 \\
90 \\
200\end{array}$ & $\begin{array}{l}1,058 \\
-- \\
-- \\
892 \\
873\end{array}$ & $\begin{array}{l}970 \\
-- \\
\overline{860} \\
840\end{array}$ & & $\begin{array}{l}\text { Yes } \\
\text { Yes } \\
\text { Yes } \\
\text { No } \\
\text { No }\end{array}$ \\
\hline
\end{tabular}


Table 17.--Location and information for wells in the shallow aquifer-Continued

\begin{tabular}{|c|c|c|c|c|c|c|c|}
\hline $\begin{array}{l}\text { Map } \\
\text { number } \\
\text { (shown } \\
\text { in fig. } \\
\text { 3) }\end{array}$ & $\begin{array}{l}\text { Location } 1 / \\
\text { (township- } \\
\text { range- } \\
\text { section) }\end{array}$ & $\begin{array}{l}\text { of } \\
\text { col } \\
\text { or }\end{array}$ & $\begin{array}{l}\text { Date } \\
\text { sample } \\
\text { llection } \\
\text { measure- } \\
\text { ment }\end{array}$ & $\begin{array}{l}\text { Total } \\
\text { well } \\
\text { depth } \\
\text { (feet) }\end{array}$ & $\begin{array}{c}\text { Land-surface } \\
\text { altitude } \\
\text { (feet above } \\
\text { National } \\
\text { Geodetic } \\
\text { Vertical } \\
\text { Datum of } \\
1929 \text { to } \\
\text { nearest } \\
5 \text { feet) } \\
\end{array}$ & $\begin{array}{l}\text { Water-level } \\
\text { altitude } \\
\text { (feet above } \\
\text { National } \\
\text { Geodetic } \\
\text { Vertical } \\
\text { Datum of } \\
1929 \text { to } \\
\text { nearest } \\
5 \text { feet) } \\
\end{array}$ & $\begin{array}{l}\text { Chemical } 2 \\
\text { analyses }\end{array}$ \\
\hline $\begin{array}{l}141 \\
142 \\
143 \\
144 \\
145\end{array}$ & $\begin{array}{l}26-34 W-2 D C A \\
30-33 W-28 D C \\
29-33 W-27 B B \\
28-34 W-11 A B \\
27-34 W-14 B A\end{array}$ & $\begin{array}{l}\star \\
\star \star \\
\star \star \\
\star \star \\
1 * \star\end{array}$ & $\begin{array}{l}09-16-76 \\
07-27-64 \\
02-10-77 \\
09-16-76\end{array}$ & -- & $\begin{array}{r}1,055 \\
910 \\
948 \\
866 \\
970\end{array}$ & $\begin{array}{l}940 \\
840 \\
930 \\
845 \\
960\end{array}$ & $\begin{array}{l}\text { No } \\
\text { No } \\
\text { No } \\
\text { No } \\
\text { No }\end{array}$ \\
\hline $\begin{array}{l}146 \\
147 \\
148 \\
149 \\
150\end{array}$ & $\begin{array}{l}28-33 W-35 B D \\
29-25 E-25 D D \\
28-24 E-18 D D \\
32-25 E-7 A A \\
29-22 E-15 D D\end{array}$ & & $\begin{array}{c}09-15-76 \\
04-68 \\
04-68 \\
-78 \\
09-26-80\end{array}$ & $\begin{array}{l}130 \\
192 \\
332 \\
362\end{array}$ & $\begin{array}{l}960 \\
950 \\
830 \\
-\overline{840}\end{array}$ & $\begin{array}{l}930 \\
895 \\
825 \\
-- \\
725\end{array}$ & $\begin{array}{r}\text { No } \\
\text { No } \\
\text { No } \\
\text { Yes }\end{array}$ \\
\hline $\begin{array}{l}151 \\
152 \\
153 \\
154\end{array}$ & $\begin{array}{l}28-22 E-3 C C C \\
28-22 E-14 B D \\
28-23 E-10 C C \\
29-23 E-27 *\end{array}$ & & $\begin{array}{l}09-24-80 \\
09-24-80 \\
09-25-80 \\
02-27-81\end{array}$ & $\begin{array}{l}300 \\
385 \\
135 \\
--\end{array}$ & $\begin{array}{l}808 \\
780 \\
840 \\
--\end{array}$ & $\begin{array}{l}745 \\
725 \\
790 \\
-\end{array}$ & Yes \\
\hline
\end{tabular}

1 Locations in 0klahoma (denoted by one asterisk) and Missouri (denoted by two asterisks) are designated with northern townships; the rest of the locations are in Kansas and are designated with southern townships.

2 Asterisk indicates that analysis is published in this report. 
Table 18.--Location and information for wells in the deep aquifer

\begin{tabular}{|c|c|c|c|c|c|c|}
\hline $\begin{array}{l}\text { Map } \\
\text { number } \\
\text { (shown } \\
\text { in fig. } \\
3 \text { ) }\end{array}$ & $\begin{array}{ll}\text { Location1/ } & \\
\text { (township- } & \text { of } \\
\text { range- } & \text { co } \\
\text { section) } & \text { or }\end{array}$ & $\begin{array}{l}\text { Date } \\
\text { of sample } \\
\text { collection } \\
\text { or measure- } \\
\text { ment }\end{array}$ & $\begin{array}{l}\text { Total } \\
\text { well } \\
\text { depth } \\
\text { (feet) }\end{array}$ & $\begin{array}{l}\text { Land- } \\
\text { surface } \\
\text { altitude } \\
\text { (feet) }\end{array}$ & $\begin{array}{l}\text { Water- } \\
\text { level } \\
\text { altitude } \\
\text { (feet) }\end{array}$ & $\begin{array}{l}\text { Chemical } 2 / \\
\text { analyses }\end{array}$ \\
\hline $\begin{array}{l}211 \\
212 \\
213 \\
214 \\
215\end{array}$ & $\begin{array}{l}32-23 E-6 D \\
33-23 E-13 A B \\
34-24 E-17 D C C \\
34-25 E-4 A B D \\
34-25 E-23 A A C\end{array}$ & $\begin{array}{l}02-26-68 \\
07-23-81 \\
07-23-81 \\
07-31-81 \\
07-30-81\end{array}$ & $\begin{array}{r}1,284 \\
1,783 \\
1,050 \\
901 \\
1,189\end{array}$ & $\begin{array}{l}910 \\
890 \\
855 \\
855 \\
950\end{array}$ & $\begin{array}{l}-- \\
700 \\
655 \\
-- \\
--\end{array}$ & $\begin{array}{l}\text { Yes } \\
\text { Yes* } \\
\text { Yes* } \\
\text { Yes* } \\
\text { Yes* }\end{array}$ \\
\hline $\begin{array}{l}216 \\
217 \\
218 \\
219 \\
220\end{array}$ & $\begin{array}{l}33-25 E-18 D A A \\
29-23 E-21 B B C * \\
28-23 E-6 C B B * \\
34-24 E-36 B B A \\
34-24 E-36 C C B\end{array}$ & $\begin{array}{l}07-30-81 \\
07-23-81 \\
07-23-81 \\
07-22-81 \\
07-23-81\end{array}$ & $\begin{array}{r}900 \\
1,077 \\
1,115 \\
1,175 \\
1,267\end{array}$ & $\begin{array}{l}870 \\
820 \\
810 \\
835 \\
830\end{array}$ & $\begin{array}{l}730 \\
-- \\
350 \\
500 \\
620\end{array}$ & $\begin{array}{l}\text { Yes* } \\
\text { Yes* } \\
\text { Yes* } \\
\text { Yes* } \\
\text { Yes* }\end{array}$ \\
\hline $\begin{array}{l}221 \\
-222 \\
223 \\
224 \\
225\end{array}$ & $\begin{array}{l}35-23 E-13 B A C \\
34-24 E-33 C C D \\
32-25-31 A A A \\
29-33 W-6 * \star \\
34-24 E-36 D B\end{array}$ & $\begin{array}{l}09-27-67 \\
09-12-42 \\
12-02-54 \\
01-31-62 \\
07-22-81\end{array}$ & $\begin{array}{r}1,206 \\
1,000 \\
564 \\
925 \\
1,094\end{array}$ & $\begin{array}{l}840 \\
834 \\
890 \\
-- \\
810\end{array}$ & $\begin{array}{l}-- \\
-- \\
-- \\
480\end{array}$ & $\begin{array}{l}\text { Yes } \\
\text { Yes } \\
\text { Yes } \\
\text { Yes } \\
\text { Yes* }\end{array}$ \\
\hline $\begin{array}{l}226 \\
227 \\
228 \\
229 \\
230\end{array}$ & $\begin{array}{l}27-33 W-10 D D A * \star \\
28-33 W-6 D A A^{* *} \\
27-33 W-3 D A D * \star \\
27-33 W-34 A D A * \star \\
32-24 E-19 C B D\end{array}$ & $\begin{array}{r}09-08-76 \\
09-08-76 \\
06-09-37 \\
+\quad 10-18-62 \\
10-27-65\end{array}$ & $\begin{array}{r}990 \\
914 \\
1,300 \\
710 \\
850\end{array}$ & $\begin{array}{l}-- \\
-- \\
-- \\
-- \\
920\end{array}$ & $\begin{array}{l}-- \\
-- \\
-- \\
--\end{array}$ & $\begin{array}{l}\text { Yes } \\
\text { Yes } \\
\text { Yes } \\
\text { Yes } \\
\text { No }\end{array}$ \\
\hline
\end{tabular}

1 Locations in Oklahoma (denoted by one asterisk) and Missouri (denoted by two asterisks) are designated with northern townships; the rest of the locations are in Kansas and are designated with southern townships.

2 Asterisk indicates that analysis is published in this report. 
Table 19.--List of surface-water sampling sites

Map number

(shown in

Station name

fig. 4)

\begin{tabular}{|c|c|}
\hline $\begin{array}{r}1 \\
2 \\
3 \\
E 24 \\
E 35\end{array}$ & $\begin{array}{l}\text { Spring River near Waco, Mo. } \\
\text { Spring River near Crestline, Kans. } \\
\text { Spring River near Badger, Kans. } \\
\text { Empire Lake } 4 \text { miles northeast of Riverton, Kans. } \\
\text { Empire Lake at Riverton, Kans. }\end{array}$ \\
\hline $\begin{array}{rr}S R S & 6 \\
& 7 \\
& 8 \\
53 & 9 \\
S 1 & 10\end{array}$ & $\begin{array}{l}\text { Spring River near Baxter Springs, Kans. } \\
\text { Center Creek near Smithfield, Mo. } \\
\text { Turkey Creek near Galena, Kans. } \\
\text { Tributary } 1 \text { to Short Creek } \\
\text { Short Creek near Central City, Mo. }\end{array}$ \\
\hline $\begin{array}{ll}52 & 11 \\
55 & 12 \\
56 & 13 \\
57 & 14 \\
130 \text { number } & 15\end{array}$ & $\begin{array}{l}\text { Short Creek } 1 \text { mile east of Galena, Kans. } \\
\text { Spring Branch near Galena, Kans. } \\
\text { Tributary } 2 \text { to Short Creek } \\
\text { Tributary } 3 \text { to Short Creek } \\
\text { Tributary } 4 \text { to Short Creek south of Galena }\end{array}$ \\
\hline $\begin{array}{ll}58 & 16 \\
59 & 17 \\
511 & 18 \\
5 / 2 & 19\end{array}$ & $\begin{array}{l}\text { Short Creek at Galena, Kans. } \\
\text { Tributary } 5 \text { to Short Creek } \\
\text { Short Creek } 2 \text { miles west of Galena, Kans. } \\
\text { Spring River tributary near Galena, Kans. } \\
\text { Chat seepage site } 1 \text { near Galena, Kans. }\end{array}$ \\
\hline $\begin{array}{r}21 \\
022 \\
1723 \\
5225\end{array}$ & $\begin{array}{l}\text { Chat seepage site } 2 \text { near Galena, Kans. } \\
\text { Willow Creek tributary } 3 \text { near Baxter Springs, Kans. } \\
\text { Brewster Ditch near Baxter Springs, Kans. } \\
\text { Willow Creek at Baxter Springs, Kans. } \\
\text { Will ow Creek } 1 \text { mile west of Baxter Springs, Kans. }\end{array}$ \\
\hline $\begin{array}{rr}\text { W. } & 26 \\
& 27 \\
28 \\
29 \\
30\end{array}$ & $\begin{array}{l}\text { Willow Creek } 2 \text { miles west of Baxter Springs, Kans. } \\
\text { Willow Creek } 3 \text { miles west of Baxter Springs, Kans. } \\
\text { Tar Creek at Treece, Kans. } \\
\text { Tar Creek } 1 \text { mile northwest of Treece, Kans. } \\
\text { Tar Creek near Cravensville, Kans. }\end{array}$ \\
\hline $\begin{array}{r}31 \\
32 \\
33 \\
34 \\
35\end{array}$ & $\begin{array}{l}\text { Shoal Creek near Galena, Kans. } \\
\text { Chat seepage site } 3 \text { near Treece, Kans. } \\
\text { Brush Creek near Riverton, Kans. } \\
\text { Cow Creek near Lawton, Kans. } \\
\text { N-8, Cherry Creek }\end{array}$ \\
\hline $\begin{array}{l}36 \\
37\end{array}$ & $\begin{array}{l}\mathrm{N}-6.9 \text {, Cherry Creek } \\
\mathrm{N}-7 \text {, Cherry Creek }\end{array}$ \\
\hline
\end{tabular}


TABLE 20.--HATER-QUALITY DATA FOR WELLS IN SHALLOH AQUIFER

Values given in 0 ither feetomicromhos $\mathrm{Per}$ centimeter at 25 C(umhos), pH units,

degreas Celsius(deg C),milligrams per liter (mg/L),or micrograms per liter(ug/L)]

MAP

NUM-

BER

FIG-

URE 3)

$\begin{array}{lll}111 & 370558094370001 & 81-08-12 \\ 112 & 370032094411301 & 82-03-18\end{array}$ $37003209441130182-03-18$ $37010809439010181-07-31$ $\begin{array}{ll}370124094390501 & 81-07-31 \\ 370408094401201 & 81-07-30\end{array}$

370428094405401 370428074424401 370539094391201

371830094444201

371051094474701

$82-03-16$
$81-07-31$

$92-03-16$

$81-07-31$

MAP

NUM-

BER

(IN

$\infty$

URE 3) STATION NUMBER SAMPLE

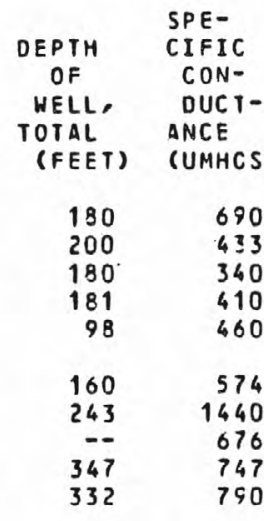

SPE-

CON-

PH

(STANDARO

NITS)

\section{8}

7.0

7. 1

6.2

6.7

7.5

8.5
7.1
7.1
7.6

7.6

CHLO-

RIDE,
OIS-

SOLVED

(MG/L

AS (L)

FLUO-
RIDEE
DIS-
SOLVED
(MGIL

SILICA,

SOLIDS,
RESIDUE

DIS-

AT 180

SOLVED DEG. $C$

$(M G / L$

AS F)

SI02)

SOLVED

(MGIL)

8.0
7.0
7.0
9.0
10
8.0
8.0
9.0
8.0

16.5

15.0

7.4

23

5.1

5.1

14
17

9.2
MAGNE-

CALCIUM DIS-

SIUM

SODIUM.

DIS-

SOLVEO

POTAS-

ALKA-

DIS- FULFAT

SOLVED SOLVED SOLV - SOILI

(MG

FIELD DIS-

AS (A) AS MG) AS NAI AS K)

CACO3) (MGN

\section{$19.8 \quad 130$}

$\begin{array}{ll}17.5 & 93 \\ 15.5 & 62\end{array}$

5.5

10

$\begin{array}{rr}3.0 & 3.7 \\ 2.0 & 4.0\end{array}$

3.0

11
12

$16.5 \quad 120$

17.0230

130

74
55

5.0

4.0 29

4.0

45

21
67

NITRO-

NITRATE

DIS-

(MG N)

DIS-

SARIUM,

DIS-

(UG/L

SOLVEO

AS

CADMIUM
DIS-

1.2

1.0
. .6
1.0

$190 \quad 130$

180
160

160
140

130
37

2.0

.7
4.0
2.0

4.0
3.0

160
220
250
32
25

$2 0 \longdiv { 1 4 0 }$

$320 \quad 120$

$\begin{array}{rr}-- & 3.9 \\ 282 & -- \\ 182 & .00 \\ 221 & 2.80 \\ 277 & .10 \\ 379 & -- \\ -- & .10 \\ 456 & -- \\ 515 & -- \\ 436 & .10\end{array}$

S AS)

AS BA)

(UGIL

AS (O)

COPPER,

DIS-

IRON

SOLVED

(USTL

SOLVED

SUG/L

$370558094370001, \quad 81-08-12$ $370032094411301 \quad 82-03-1$ 370108094390101 81-07-31

.1
.1
.1
.1
.2
.2
.3
.1
.7
1.1

10
3.9
.00
.00
.10
0
.10
$0-$
.10

a

100
100
0
100
100
100
100
100
100
100

10

350
20
10
10
5700
3700
1300
30
40
30 
TABLE 20.--WATER-QUALITY DATA FOR WELLS IN SHALLOW AQUIFER--CONTINUED

BER

FIG

URE 31

DATE
OPF
STATION NUMBER SAMPLE

MANGA-

LEAD- NES

SELE-

OLVED SOLVED

NIUM.

ZINC,

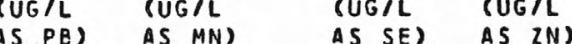

$\begin{array}{lll}111 & 370558094370001 & 81-08-12 \\ 11,2 & 370032094411301 & 82-03-19 \\ 11,3 & 370108094390101 & 81-07-31 \\ 1,14 & 370124094390501 & 81-07-31 \\ 11,5 & 370408094401201 & 81-07-30 \\ & & \\ 116 & 370428094405401 & 82-03-16 \\ 11,7 & 370428094424401 & 81-07-31 \\ 11,8 & 370639094391,201 & 82-03-16 \\ 11,9 & 37183009444201 & 82-03-18 \\ 1,20 & 371,051094474701 & 81-07-31\end{array}$

$\begin{array}{rr}0 & 50 \\ 0 & 10 \\ 0 & 0 \\ 0 & 10 \\ 0 & 100 \\ 0 & 180 \\ 0 & 420 \\ 30 & 0 \\ 0 & 30 \\ 0 & 10\end{array}$

$50 \quad 0 \quad 1500$

400


TABLE 21.--WATER-QUALITY DATA FOR MINES IN SHALLOW AQUIFER

CValues given in either feetemicromhos per centimeter at 25 C(umhos)epH units.

degrees Celsius(des C),milligrams per liter(mg/L),or micrograms per liter(ug/L) eE denotes estimated valuej

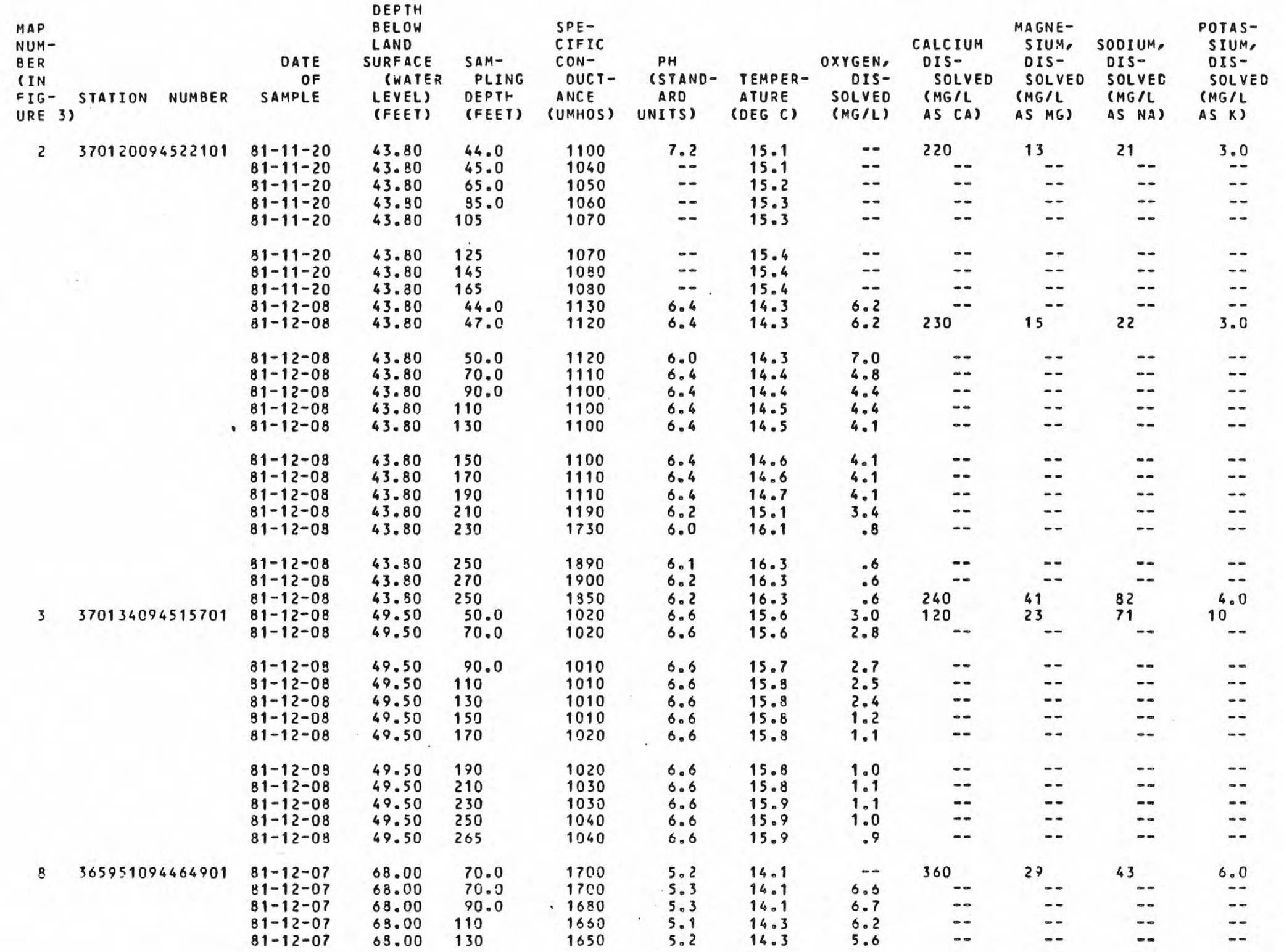


TABLE 21.--WATER-QUALITY DATA FOR MINES IN SHALLOW AQUIFER--CONTINUED

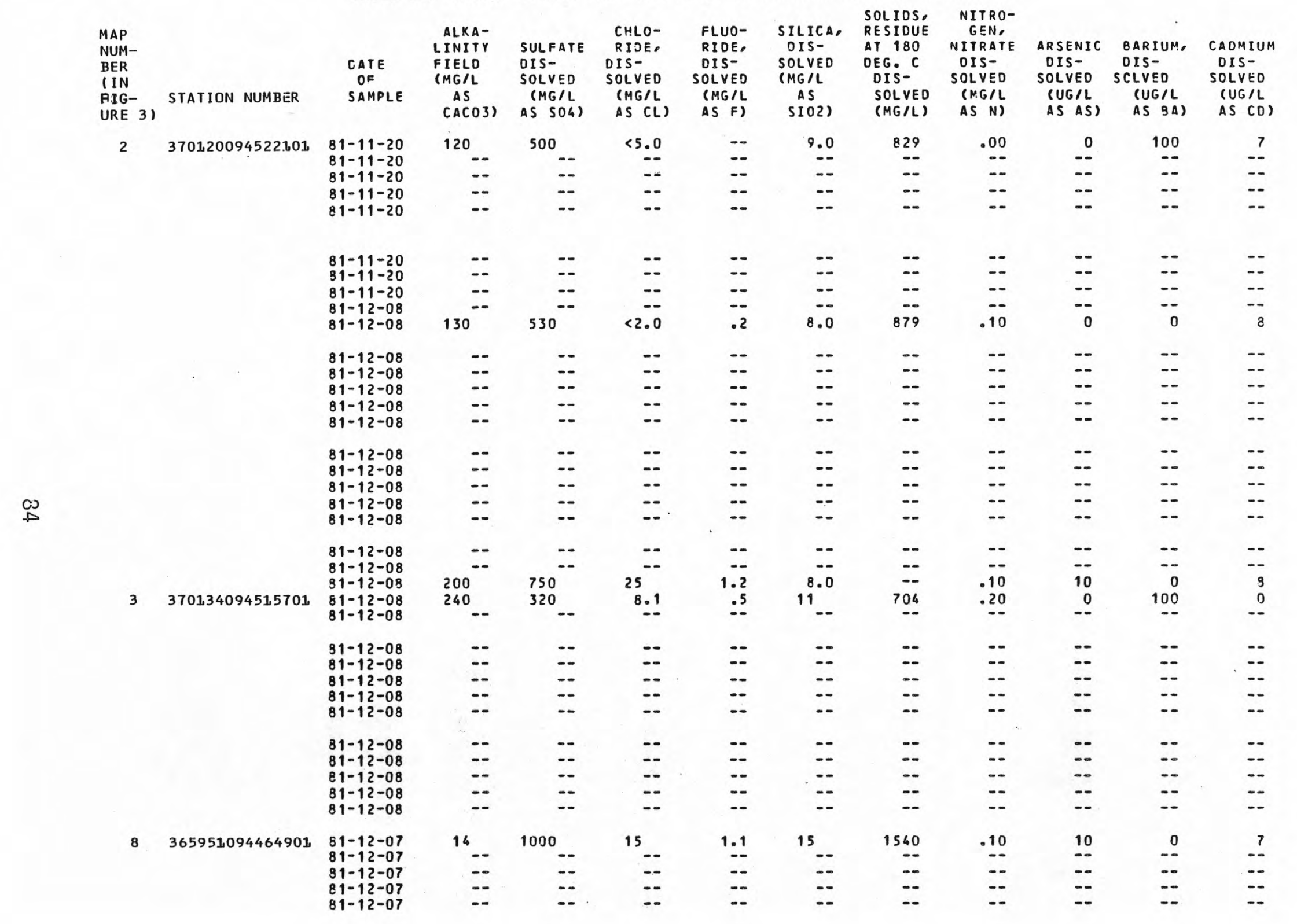


TABLE 21.--WATER-QUALITY DATA FOR NINES IN SHALLOW AQUIFER--CONTINUED

\begin{tabular}{|c|c|c|c|c|c|c|c|c|}
\hline $\begin{array}{l}\text { MAP } \\
\text { NUM- } \\
\text { BER } \\
\text { I IN } \\
\text { FIG- } \\
\text { URE } 3\end{array}$ & STATION NUMBER & $\begin{array}{c}\text { DATE } \\
\text { OF } \\
\text { SAMPLE }\end{array}$ & $\begin{array}{l}\text { COPPER, } \\
\text { OIS- } \\
\text { SOLVEO } \\
\text { (UG/L } \\
\text { AS CU) }\end{array}$ & $\begin{array}{l}\text { IRON, } \\
\text { DIS- } \\
\text { SOLVEO } \\
\text { (UGIL } \\
\text { AS FE) }\end{array}$ & $\begin{array}{l}\text { LEAD, } \\
\text { DIS- } \\
\text { SOLVED } \\
\text { (UG/L. } \\
\text { AS PE) }\end{array}$ & $\begin{array}{l}\text { MANGA- } \\
\text { NESE } \\
\text { DIS- } \\
\text { SOLVED } \\
\text { (UG/L } \\
\text { AS MN) }\end{array}$ & $\begin{array}{l}\text { SELE- } \\
\text { NIUM, } \\
\text { DIS- } \\
\text { SOLVED } \\
\text { (UG/L } \\
\text { AS SE) }\end{array}$ & $\begin{array}{l}\text { ZINC, } \\
\text { DIS- } \\
\text { SOLVEO } \\
\text { (UG/L } \\
\text { AS ZN) }\end{array}$ \\
\hline \multirow[t]{5}{*}{2} & $3701,200945221,01$ & $\begin{array}{l}81-11-20 \\
81-11-20 \\
31-11-20 \\
81-11-20 \\
81-11-20\end{array}$ & $\begin{array}{l}10 \\
-- \\
-- \\
--\end{array}$ & $\begin{array}{l}20 \\
=- \\
=- \\
--\end{array}$ & $\begin{array}{l}0 \\
-- \\
-- \\
--\end{array}$ & $\begin{array}{c}100 \\
-- \\
-- \\
--\end{array}$ & $\begin{array}{l}1 \\
-- \\
-- \\
--\end{array}$ & $\begin{array}{c}1900 \\
-- \\
-- \\
--\end{array}$ \\
\hline & & $\begin{array}{l}81-11-20 \\
81-11-20 \\
81-11-20 \\
81-12-08 \\
81-12-08\end{array}$ & $\begin{array}{l}-- \\
-- \\
-- \\
0\end{array}$ & $\begin{array}{l}\therefore \\
\therefore \\
\therefore \\
190\end{array}$ & $\begin{array}{l}-- \\
-- \\
-- \\
0\end{array}$ & $\begin{array}{l}-- \\
\overline{--} \\
--\end{array}$ & $\begin{array}{l}=- \\
=- \\
--\end{array}$ & $\begin{array}{l}=- \\
\overline{--} \\
2200\end{array}$ \\
\hline & & $\begin{array}{l}81-12-08 \\
81-12-08 \\
31-12-08 \\
81-12-08 \\
81-12-08\end{array}$ & $\begin{array}{l}= \\
=- \\
= \\
=\end{array}$ & $\begin{array}{l}-- \\
- \\
-- \\
--\end{array}$ & $\begin{array}{l}=- \\
-- \\
--\end{array}$ & $\begin{array}{l}=- \\
=- \\
=- \\
--\end{array}$ & $\begin{array}{l}=- \\
=- \\
--\end{array}$ & $\begin{array}{l}-- \\
-- \\
-- \\
--\end{array}$ \\
\hline & & $\begin{array}{l}81-12-08 \\
81-12-08 \\
81-12-08 \\
81-12-08 \\
81-12-08\end{array}$ & $\begin{array}{l}-- \\
-- \\
-- \\
--\end{array}$ & $\begin{array}{l}=- \\
\overline{-} \\
-- \\
-\end{array}$ & $\begin{array}{l}-- \\
\overline{-} \\
-- \\
--\end{array}$ & $\begin{array}{l}=- \\
-- \\
-- \\
--\end{array}$ & $\begin{array}{l}=- \\
-- \\
--\end{array}$ & $\begin{array}{l}-- \\
=- \\
-- \\
--\end{array}$ \\
\hline & 370134094515701 & $\begin{array}{l}81-12-08 \\
81-12-08 \\
31-12-09 \\
81-12-08 \\
81-12-08\end{array}$ & $\begin{array}{l}-- \\
20 \\
20 \\
--\end{array}$ & $\begin{array}{r}-- \\
24000 \\
30 \\
--\end{array}$ & $\begin{array}{r}-- \\
-- \\
0 \\
0 \\
--\end{array}$ & $\begin{array}{r}-- \\
1200 \\
30 \\
--\end{array}$ & $\begin{array}{r}-- \\
-- \\
2 \\
--\end{array}$ & $\begin{array}{r}30 \\
3600 \\
40 \\
--\end{array}$ \\
\hline \multirow{2}{*}{3} & & $\begin{array}{l}81-12-09 \\
81-12-09 \\
81-12-09 \\
81-12-09 \\
81-12-08\end{array}$ & $\begin{array}{l}-- \\
-- \\
-- \\
--\end{array}$ & $\begin{array}{l}-- \\
-- \\
--\end{array}$ & $\begin{array}{l}-- \\
-- \\
--\end{array}$ & $\begin{array}{l}-- \\
=- \\
--\end{array}$ & $\begin{array}{l}-- \\
-- \\
--\end{array}$ & $\begin{array}{l}-- \\
=- \\
=- \\
--\end{array}$ \\
\hline & & $\begin{array}{l}81-12-08 \\
81-12-08 \\
81-12-08 \\
81-12-08 \\
81-12-08\end{array}$ & $\begin{array}{l}-- \\
-- \\
--\end{array}$ & $\begin{array}{l}=- \\
\therefore- \\
=-\end{array}$ & $\begin{array}{l}-- \\
-- \\
-- \\
--\end{array}$ & $\begin{array}{l}-- \\
-- \\
--\end{array}$ & $\begin{array}{l}-- \\
-- \\
--\end{array}$ & $\begin{array}{l}-- \\
=- \\
--\end{array}$ \\
\hline 8 & 365951094464901 & $\begin{array}{l}81-12-07 \\
81-12-07 \\
81-12-07 \\
81-12-07 \\
81-12-07\end{array}$ & $\begin{array}{l}80 \\
=- \\
=- \\
--\end{array}$ & $\begin{array}{r}2000 \\
0- \\
0 \\
0 \\
-\end{array}$ & $\begin{array}{l}0 \\
-- \\
-- \\
--\end{array}$ & $\begin{array}{r}1200 \\
=- \\
=- \\
--\end{array}$ & $\begin{array}{l}4 \\
-- \\
-- \\
--\end{array}$ & $\begin{array}{r}4400 \\
=- \\
=- \\
=-\end{array}$ \\
\hline
\end{tabular}


TABLE 21.--WATER-QUALITY DATA FOR MINES IN SHALLOW AQUIFER--CONTINUED

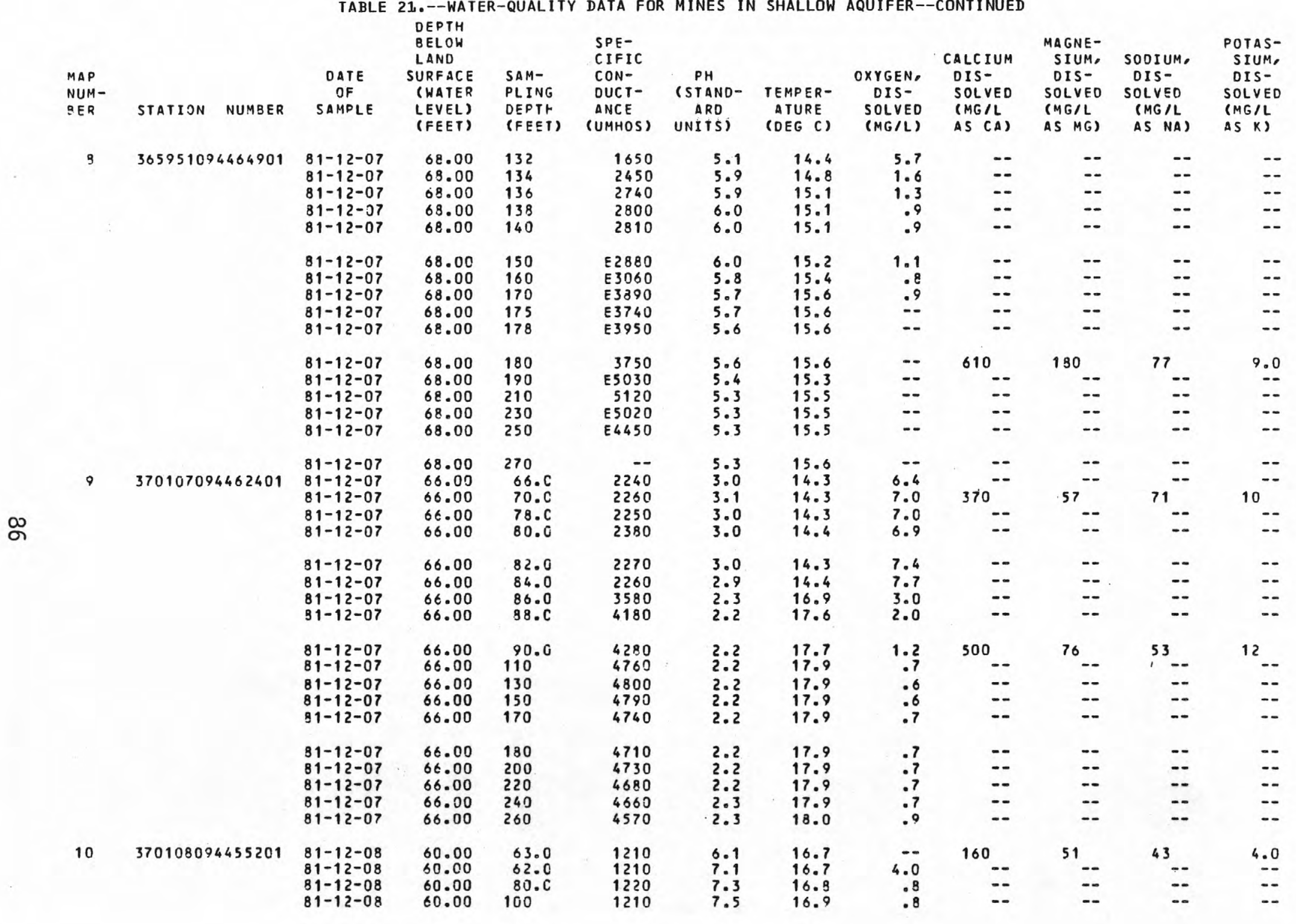


TABLE 21.--WATER-QUALITY DATA FOR MINES IN SHALLOW AQUIFER--CONTINUED

\begin{tabular}{|c|c|c|c|c|c|c|c|c|c|c|c|c|}
\hline $\begin{array}{l}\text { MAP } \\
\text { NUM- } \\
\text { BER } \\
\text { (IN } \\
\text { FIG- } \\
\text { URE 3) }\end{array}$ & STATION NUMBER & $\begin{array}{c}\text { CATE } \\
\text { CF } \\
\text { SAMPLE }\end{array}$ & $\begin{array}{l}\text { ALKA- } \\
\text { LINITY } \\
\text { FIELD } \\
\text { (MG/L } \\
\text { AS } \\
\text { CACOS) }\end{array}$ & $\begin{array}{l}\text { SULFATE } \\
\text { DIS- } \\
\text { SOLVED } \\
\text { (MG/L } \\
\text { AS SOL) }\end{array}$ & $\begin{array}{l}\text { CHLOO- } \\
\text { RIDE. } \\
\text { DIS- } \\
S C L V E O \\
(H G / L \\
A S C L)\end{array}$ & $\begin{array}{l}\text { FLUO- } \\
\text { RIDE, } \\
\text { OIS- } \\
\text { SCLVED } \\
\text { (MG/L } \\
\text { AS F) }\end{array}$ & $\begin{array}{l}\text { SILICA } \\
\text { OIS- } \\
\text { SOLVED } \\
\text { (MG/L } \\
\text { AS } \\
\text { SIC2) }\end{array}$ & $\begin{array}{l}\text { SOLIOS, } \\
\text { RESIDUE } \\
\text { AT } 180 \\
\text { OEG. C } \\
\text { DIS- } \\
\text { SOLVED } \\
\text { (MGIL) }\end{array}$ & $\begin{array}{l}\text { NITRO- } \\
\text { GEN, } \\
\text { NITRATE } \\
\text { DIS- } \\
\text { SOLVED } \\
\text { (MG L } \\
\text { AS N) }\end{array}$ & $\begin{array}{l}\text { ARSENIC } \\
\text { OIS- } \\
\text { SOLVED } \\
\text { (UG/L } \\
\text { AS AS) }\end{array}$ & $\begin{array}{l}\text { BARIUM, } \\
\text { CIS- } \\
\text { SOLVED } \\
\text { (UG/L } \\
\text { AS BA) }\end{array}$ & $\begin{array}{c}\text { CADMIUM } \\
\text { DIS- } \\
\text { SOLVEO } \\
\text { (UG/L } \\
\text { AS CO) }\end{array}$ \\
\hline \multirow[t]{3}{*}{8} & \multirow[t]{3}{*}{365951094464901} & $\begin{array}{l}31-12-07 \\
81-12-07 \\
81-12-07 \\
81-12-07 \\
81-12-07\end{array}$ & $\begin{array}{l}-- \\
-- \\
-- \\
--\end{array}$ & $\begin{array}{l}-- \\
=- \\
--\end{array}$ & $\begin{array}{l}- \\
- \\
- \\
-\end{array}$ & $\begin{array}{l}=- \\
=- \\
=- \\
--\end{array}$ & $\begin{array}{l}-- \\
-- \\
-- \\
--\end{array}$ & $\begin{array}{l}-- \\
-- \\
-- \\
--\end{array}$ & $\begin{array}{l}-- \\
-- \\
-- \\
--\end{array}$ & $\begin{array}{l}-- \\
\overline{--} \\
--\end{array}$ & $\begin{array}{l}-- \\
-- \\
-- \\
--\end{array}$ & $\begin{array}{l}-- \\
-- \\
-- \\
--\end{array}$ \\
\hline & & $\begin{array}{l}81-12-07 \\
81-12-07 \\
81-12-07 \\
81-12-07 \\
81-12-07\end{array}$ & $\begin{array}{l}-\infty \\
- \\
-\end{array}$ & $\begin{array}{l}-- \\
=- \\
=\end{array}$ & $\begin{array}{l}-\infty \\
\therefore \\
-\infty\end{array}$ & $\begin{array}{l}-- \\
-- \\
-- \\
--\end{array}$ & $\begin{array}{l}-- \\
-- \\
-- \\
--\end{array}$ & $\begin{array}{l}-- \\
-- \\
-- \\
--\end{array}$ & $\begin{array}{l}-- \\
-- \\
-- \\
--\end{array}$ & $\begin{array}{l}-- \\
-- \\
-- \\
--\end{array}$ & $\begin{array}{l}-- \\
-- \\
--\end{array}$ & $\begin{array}{l}-- \\
-- \\
-- \\
--\end{array}$ \\
\hline & & $\begin{array}{l}81-12-07 \\
81-12-07 \\
81-12-07 \\
81-12-07 \\
81-12-07\end{array}$ & $\begin{array}{r}600 \\
=- \\
=- \\
=-\end{array}$ & $\begin{array}{r}2200 \\
\ldots \\
0- \\
\\
-\end{array}$ & $\begin{array}{c}8.1 \\
=- \\
- \\
=-\end{array}$ & $\begin{array}{l}1.8 \\
-- \\
-- \\
--\end{array}$ & $\begin{array}{c}6.0 \\
-- \\
-- \\
--\end{array}$ & $\begin{array}{r}3220 \\
=- \\
=- \\
=-\end{array}$ & $\begin{array}{c}.00 \\
-- \\
-- \\
--\end{array}$ & $\begin{array}{l}20 \\
-- \\
-- \\
--\end{array}$ & $\begin{array}{l}0 \\
-- \\
-- \\
--\end{array}$ & $\begin{array}{l}14 \\
-- \\
-- \\
--\end{array}$ \\
\hline \multirow[t]{4}{*}{9} & \multirow[t]{4}{*}{$3701070944624^{\prime} 01$} & $\begin{array}{l}81-12-07 \\
81-12-07 \\
81-12-07 \\
81-12-07 \\
81-12-07\end{array}$ & $\begin{array}{l}-- \\
=- \\
-- \\
--\end{array}$ & $1300^{--}$ & $20^{--}$ & $\begin{array}{l}-- \\
1.6 \\
-- \\
--\end{array}$ & $45^{--}$ & $\begin{array}{r}-- \\
1880 \\
=- \\
--\end{array}$ & $\begin{array}{l}-- \\
.0 \\
.00 \\
--\end{array}$ & $\begin{array}{l}-- \\
-- \\
20 \\
--\end{array}$ & $\begin{array}{l}-- \\
- \\
-- \\
--\end{array}$ & $\begin{array}{l}-- \\
-- \\
-- \\
--\end{array}$ \\
\hline & & $\begin{array}{l}81-12-07 \\
81-12-07 \\
81-12-07 \\
81-12-07\end{array}$ & $=-$ & $\begin{array}{l}\ldots \\
-\infty \\
-\infty\end{array}$ & $\begin{array}{l}- \\
\therefore \\
\therefore\end{array}$ & $\begin{array}{l}-- \\
=- \\
--\end{array}$ & $\begin{array}{l}-- \\
-- \\
--\end{array}$ & $\begin{array}{l}-- \\
-- \\
--\end{array}$ & $\begin{array}{l}-- \\
-- \\
--\end{array}$ & $\begin{array}{l}-- \\
-- \\
--\end{array}$ & $\begin{array}{l}-- \\
-- \\
--\end{array}$ & $\begin{array}{l}=- \\
-- \\
--\end{array}$ \\
\hline & & $\begin{array}{l}31-21-07 \\
81-12-07 \\
81-12-07 \\
81-12-07 \\
81-12-07\end{array}$ & $\begin{array}{l}-- \\
-- \\
-- \\
--\end{array}$ & $3000=$ & $\begin{array}{c}12 \\
=- \\
=- \\
--\end{array}$ & $\begin{array}{l}10 \\
-- \\
--\end{array}$ & 43 & $\begin{array}{l}-- \\
-- \\
-- \\
--\end{array}$ & $\begin{array}{c}.00 \\
-- \\
-- \\
--\end{array}$ & $\begin{array}{c}120 \\
-- \\
-- \\
--\end{array}$ & $\begin{array}{l}0 \\
-- \\
-- \\
--\end{array}$ & $\begin{array}{l}85 \\
-- \\
-- \\
--\end{array}$ \\
\hline & & $\begin{array}{l}81-12-07 \\
31-12-07 \\
31-12-07 \\
81-12-07 \\
81-12-07\end{array}$ & $\begin{array}{l}-- \\
-- \\
--\end{array}$ & $\begin{array}{l}-- \\
-- \\
-- \\
-\infty\end{array}$ & $\begin{array}{l}- \\
- \\
- \\
-\end{array}$ & $\begin{array}{l}-- \\
-- \\
--\end{array}$ & $\begin{array}{l}-- \\
-- \\
-- \\
--\end{array}$ & $\begin{array}{l}-- \\
-- \\
-- \\
--\end{array}$ & $\begin{array}{l}-- \\
-- \\
-- \\
--\end{array}$ & $\begin{array}{l}-- \\
-- \\
--\end{array}$ & $\begin{array}{l}-- \\
- \\
--\end{array}$ & $\begin{array}{l}-- \\
-- \\
--\end{array}$ \\
\hline 10 & 370108094455201 & $\begin{array}{l}31-12-08 \\
81-12-08 \\
81-12-08 \\
81-12-08\end{array}$ & 260 & $\begin{array}{r}450 \\
=- \\
=-\end{array}$ & $\begin{array}{c}6.0 \\
-- \\
-\end{array}$ & $\begin{array}{l}-4 \\
-- \\
--\end{array}$ & 11 & $\begin{array}{r}874 \\
-- \\
--\end{array}$ & $\begin{array}{l}-- \\
-- \\
--\end{array}$ & $\begin{array}{l}0 \\
-- \\
--\end{array}$ & $\begin{array}{l}0 \\
-- \\
--\end{array}$ & $\begin{array}{l}0 \\
-- \\
--\end{array}$ \\
\hline
\end{tabular}


TABLE 21.--WATER-QUALITY DATA FOR MINIES IN SHALLOW AQUIFER--CONTINUED

\begin{tabular}{|c|c|c|c|c|c|c|c|c|}
\hline $\begin{array}{l}\text { MAP } \\
\text { NUM- } \\
\text { BER } \\
\text { IIN } \\
\text { FIG- } \\
\text { URE 31 }\end{array}$ & STATION NUMBER & $\begin{array}{c}\text { DATE } \\
\text { OF } \\
\text { SAMPLE }\end{array}$ & $\begin{array}{l}\text { COPPER, } \\
\text { OIS- } \\
\text { SOLVED } \\
\text { (UGIL } \\
\text { AS CU) }\end{array}$ & $\begin{array}{l}\text { IRON } \\
\text { OIS- } \\
\text { SOLVED } \\
\text { (UGIL } \\
\text { AS FE) }\end{array}$ & $\begin{array}{c}\text { LEAC, } \\
\text { OIS- } \\
\text { SOLVED } \\
\text { (UGIL } \\
\text { AS PB) }\end{array}$ & $\begin{array}{l}\text { MANGA- } \\
\text { NESE, } \\
\text { OIS- } \\
\text { SOLVED } \\
\text { (UG/L } \\
\text { AS MN) }\end{array}$ & $\begin{array}{l}\text { SELE- } \\
\text { NIUM, } \\
\text { DIS- } \\
\text { SOLVED } \\
\text { (UG/L } \\
\text { AS SE) }\end{array}$ & $\begin{array}{l}\text { ZINC, } \\
\text { DIS- } \\
\text { SOLVED } \\
\text { (UGIL } \\
\text { AS ZN) }\end{array}$ \\
\hline \multirow[t]{3}{*}{8} & 365951094464901 & $\begin{array}{l}81-12-07 \\
81-12-07 \\
81-12-07 \\
81-12-07 \\
81-12-07\end{array}$ & $\begin{array}{l}-- \\
\overline{--} \\
--\end{array}$ & $\begin{array}{l}-- \\
-- \\
--\end{array}$ & $\begin{array}{l}-- \\
\overline{-} \\
--\end{array}$ & $\begin{array}{l}-- \\
-- \\
-- \\
--\end{array}$ & $\begin{array}{l}-- \\
-- \\
-- \\
--\end{array}$ & $\begin{array}{l}-- \\
-- \\
-- \\
--\end{array}$ \\
\hline & & $\begin{array}{l}81-12-07 \\
81-12-07 \\
81-12-07 \\
81-12-07 \\
81-12-07\end{array}$ & $\begin{array}{l}-- \\
-- \\
--\end{array}$ & $\begin{array}{l}-- \\
-- \\
-- \\
--\end{array}$ & $\begin{array}{l}-- \\
-- \\
--\end{array}$ & $\begin{array}{l}-- \\
-- \\
-- \\
--\end{array}$ & $\begin{array}{l}-\therefore \\
=- \\
=- \\
--\end{array}$ & $\begin{array}{l}-- \\
-- \\
-- \\
--\end{array}$ \\
\hline & & $\begin{array}{l}81-12-07 \\
81-12-07 \\
51-12-07 \\
81-12-07 \\
81-12-07\end{array}$ & $\begin{array}{l}70 \\
-- \\
-- \\
--\end{array}$ & $\begin{array}{r}220000 \\
=- \\
-- \\
--\end{array}$ & $\begin{array}{l}0 \\
-- \\
-- \\
--\end{array}$ & $\begin{array}{r}2700 \\
=- \\
=- \\
=-\end{array}$ & $\begin{array}{l}8 \\
-- \\
-- \\
--\end{array}$ & $\begin{array}{r}30000 \\
=- \\
=- \\
=-\end{array}$ \\
\hline \multirow[t]{4}{*}{9} & 370107094462401 & $\begin{array}{l}81-12-07 \\
81-12-07 \\
81-12-07 \\
81-12-07 \\
81-12-07\end{array}$ & 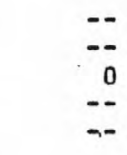 & $\begin{array}{r}-- \\
0 \\
200 \\
=- \\
--\end{array}$ & $\begin{array}{l}-- \\
40 \\
-- \\
--\end{array}$ & $\begin{array}{r}-- \\
6400 \\
-- \\
--\end{array}$ & $\begin{array}{r}-- \\
-- \\
-- \\
--\end{array}$ & $\begin{array}{r}-- \\
3800 \\
-- \\
--\end{array}$ \\
\hline & & $\begin{array}{l}81-12-07 \\
81-12-07 \\
81-12-07 \\
81-12-07\end{array}$ & $\overline{--}$ & $\begin{array}{l}-- \\
-- \\
--\end{array}$ & $\begin{array}{l}-- \\
-- \\
--\end{array}$ & $\begin{array}{l}-- \\
-- \\
--\end{array}$ & $\begin{array}{l}-- \\
-- \\
--\end{array}$ & $\begin{array}{l}-- \\
-- \\
--\end{array}$ \\
\hline & & $\begin{array}{l}81-12-07 \\
81-12-07 \\
81-12-07 \\
81-12-07 \\
81-12-07\end{array}$ & $\begin{array}{l}10 \\
-- \\
-- \\
--\end{array}$ & $\begin{array}{r}560000 \\
=- \\
=- \\
--\end{array}$ & $\begin{array}{c}100 \\
-- \\
=- \\
--\end{array}$ & $\begin{array}{c}4100 \\
=- \\
=- \\
--\end{array}$ & $\begin{array}{l}22 \\
-- \\
-- \\
--\end{array}$ & $\begin{array}{c}43000 \\
=- \\
-- \\
-- \\
--\end{array}$ \\
\hline & & $\begin{array}{l}81-12-07 \\
81-12-07 \\
81-12-07 \\
81-12-07 \\
81-12-07\end{array}$ & $\begin{array}{l}-- \\
-- \\
--\end{array}$ & $\begin{array}{l}-- \\
-- \\
--\end{array}$ & $\begin{array}{l}-- \\
-- \\
--\end{array}$ & $\begin{array}{l}-- \\
-- \\
-- \\
--\end{array}$ & $\begin{array}{l}-- \\
-- \\
--\end{array}$ & $\begin{array}{l}= \\
-- \\
--\end{array}$ \\
\hline 10 & 3701,08094455201 & $\begin{array}{l}81-12-08 \\
81-12-08 \\
81-12-08 \\
81-12-08\end{array}$ & $\begin{array}{l}30 \\
-- \\
--\end{array}$ & $\begin{array}{r}1400 \\
=- \\
=-\end{array}$ & $\begin{array}{l}0 \\
\therefore- \\
\therefore\end{array}$ & $\begin{array}{c}410 \\
-- \\
-- \\
--\end{array}$ & $\begin{array}{l}3 \\
-- \\
--\end{array}$ & $\begin{array}{l}50 \\
-- \\
--\end{array}$ \\
\hline
\end{tabular}


TABLE 21,--WATER-QUALITY DATA FOR MINES IN SHALLOW AQUIFER--CONTINUED

\begin{tabular}{|c|c|c|c|c|c|c|c|c|c|}
\hline $\begin{array}{l}\text { BELOW } \\
\text { LAND } \\
\text { SURFACE } \\
\text { (WWTER } \\
\text { LEVEL) } \\
\text { (FEET) }\end{array}$ & $\begin{array}{l}\text { SAM- } \\
\text { PLING } \\
\text { OEPTH } \\
\text { (FEET) }\end{array}$ & $\begin{array}{l}\text { SPE- } \\
\text { CIFIC } \\
\text { CON- } \\
\text { CUCT- } \\
\text { ANCE } \\
\text { (UMHOS) }\end{array}$ & $\begin{array}{l}\text { PH } \\
\text { (STAND- } \\
\text { ARD } \\
\text { UNITS) }\end{array}$ & $\begin{array}{l}\text { TEMPER- } \\
\text { ATURE } \\
(D \leq G \quad C)\end{array}$ & $\begin{array}{r}\text { OXYGEN } \\
\text { DIS- } \\
\text { SCLVED } \\
\text { (MG/L) }\end{array}$ & $\begin{array}{l}\text { CALCIUM } \\
\text { DIS- } \\
\text { SOLVED } \\
\text { (MG/L } \\
\text { AS CA) }\end{array}$ & $\begin{array}{l}\text { MAGNE- } \\
\text { SIUM. } \\
\text { OIS- } \\
\text { SOLVED } \\
\text { (MG/L } \\
\text { AS MG) }\end{array}$ & $\begin{array}{l}\text { SODIUM, } \\
\text { DIS- } \\
\text { SOLVED } \\
\text { (MG/L } \\
\text { AS NA) }\end{array}$ & $\begin{array}{l}\text { POTAS- } \\
\text { SIUM. } \\
\text { DIS- } \\
\text { SOLVED } \\
\text { (MG/L. } \\
\text { AS K) }\end{array}$ \\
\hline $\begin{array}{r}60.00 \\
60.00 \\
60.00 \\
-.- \\
59.00\end{array}$ & $\begin{array}{l}120 \\
140 \\
160 \\
140 \\
300\end{array}$ & $\begin{array}{l}1210 \\
1210 \\
1210 \\
1220 \\
1150\end{array}$ & $\begin{array}{l}7.6 \\
7.7 \\
7.8 \\
6.6 \\
7.4\end{array}$ & $\begin{array}{r}16.9 \\
16.9 \\
16.9 \\
16.9 \\
--\end{array}$ & $\begin{array}{l}.7 \\
.7 \\
.7 \\
.6 \\
-. .\end{array}$ & $160^{--}$ & $51^{--}$ & $42^{--}$ & $\begin{array}{l}-- \\
-- \\
4.0 \\
--\end{array}$ \\
\hline $\begin{array}{l}59.00 \\
60.00 \\
60.00 \\
60.00 \\
60.00\end{array}$ & $\begin{array}{l}60.0 \\
60 . C \\
80.0 \\
100 \\
120\end{array}$ & $\begin{array}{l}1070 \\
1010 \\
1040 \\
1060 \\
1060\end{array}$ & $\begin{array}{c}7.4 \\
=- \\
=- \\
=-\end{array}$ & $\begin{array}{l}15.1 \\
15.1 \\
15.2 \\
15.2 \\
15.2\end{array}$ & $\begin{array}{l}-- \\
=- \\
--\end{array}$ & $\begin{array}{r}210 \\
=- \\
=- \\
=-\end{array}$ & $\begin{array}{l}20 \\
-- \\
=- \\
--\end{array}$ & $\begin{array}{c}12 \\
\ldots \\
0 \\
-.\end{array}$ & $\begin{array}{c}6.0 \\
-- \\
-- \\
--\end{array}$ \\
\hline $\begin{array}{r}60.00 \\
60.00 \\
60.00 \\
48.40 \\
. .\end{array}$ & $\begin{array}{l}140 \\
150 \\
150 \\
50.0 \\
100\end{array}$ & $\begin{array}{r}1220 \\
1220 \\
1220 \\
1260 \\
--\end{array}$ & $\begin{array}{l}-- \\
-- \\
7.2 \\
7.1\end{array}$ & $\begin{array}{l}15.6 \\
15.6 \\
15.6 \\
15.0 \\
14.7\end{array}$ & $\begin{array}{l}-- \\
-- \\
5.2 \\
4.7\end{array}$ & $250^{--}$ & 29 & $20^{--}$ & $\begin{array}{c}-- \\
-- \\
3.0 \\
-.\end{array}$ \\
\hline $\begin{array}{r}=- \\
=- \\
43.00 \\
57.00\end{array}$ & $\begin{array}{l}150 \\
200 \\
250 \\
110 \\
58.0\end{array}$ & $\begin{array}{l}1210 \\
1240 \\
1240 \\
2340\end{array}$ & $\begin{array}{l}7.1 \\
7.1 \\
7.0 \\
7.1 \\
5.5\end{array}$ & $\begin{array}{r}14.5 \\
14.7 \\
15.0 \\
-- \\
15.0\end{array}$ & $\begin{array}{l}4.4 \\
4.3 \\
4.2 \\
-. \\
7.7\end{array}$ & $\begin{array}{l}260 \\
260 \\
110 \\
350\end{array}$ & $\begin{array}{r}30 \\
30 \\
31 \\
150\end{array}$ & $\begin{array}{r}21 \\
21 \\
120 \\
120\end{array}$ & $\begin{array}{l}3.0 \\
-- \\
3.0 \\
5.0 \\
9.0\end{array}$ \\
\hline $\begin{array}{r}-- \\
\overline{--} \\
\overline{--} \\
41.00\end{array}$ & $\begin{array}{l}100 \\
150 \\
200 \\
250 \\
61.0\end{array}$ & $\begin{array}{r}-- \\
-\overline{-} \\
2440 \\
557\end{array}$ & $\begin{array}{l}5.9 \\
5.9 \\
5.9 \\
5.9 \\
7.0\end{array}$ & $\begin{array}{l}15.4 \\
15.4 \\
15.5 \\
15.5 \\
17.0\end{array}$ & $\begin{array}{l}0.0 \\
5.2 \\
5.4 \\
5.2 \\
-.-\end{array}$ & $380^{--}$ & $\begin{array}{c}-- \\
150^{--} \\
8.0\end{array}$ & $130^{--}$ & $\begin{array}{c}-- \\
-- \\
=- \\
5.0 \\
5.0\end{array}$ \\
\hline $\begin{array}{r}38.00 \\
46.00 \\
-- \\
--\end{array}$ & $\begin{array}{l}100 \\
47.0 \\
96.0 \\
196 \\
246\end{array}$ & $\begin{array}{c}504 \\
305 \\
-- \\
-- \\
--\end{array}$ & $\begin{array}{l}6.7 \\
7.1 \\
7.0 \\
7.0 \\
7.0\end{array}$ & $\begin{array}{l}16.5 . \\
16.0 \\
15.9 \\
15.9 \\
15.9\end{array}$ & $\begin{array}{l}-. \\
1.9 \\
.4 \\
.2 \\
.0\end{array}$ & $\begin{array}{r}79 \\
130 \\
-- \\
-- \\
--\end{array}$ & $\begin{array}{r}9.0 \\
11 \\
=- \\
--\end{array}$ & $\begin{array}{r}19 \\
25 \\
-- \\
--\end{array}$ & $\begin{array}{r}5.0 \\
5.0 \\
-- \\
--\end{array}$ \\
\hline $\begin{array}{r}29.50 \\
=- \\
=- \\
--\end{array}$ & $\begin{array}{r}31.0 \\
80.0 \\
130 \\
130\end{array}$ & $\begin{array}{r}1070 \\
2450 \\
--\end{array}$ & $\begin{array}{l}7.2 \\
6.2 \\
6.2 \\
6.2\end{array}$ & $\begin{array}{l}14.0 \\
15.9 \\
16.0 \\
16.2\end{array}$ & $\begin{array}{r}5.4 \\
.4 \\
.4 \\
.4\end{array}$ & 600 & $\begin{array}{l}20 \\
42^{--}\end{array}$ & ${ }^{18} 0^{--}$ & $\begin{array}{r}4.0 \\
-- \\
4.0 \\
---\end{array}$ \\
\hline $\begin{array}{r}43.00 \\
-0\end{array}$ & $50 . \bar{C}$ & $\begin{array}{l}411 \\
367\end{array}$ & $\begin{array}{l}6.7 \\
6.2\end{array}$ & $\begin{array}{l}13.0 \\
12.0\end{array}$ & 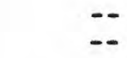 & $\begin{array}{l}33 \\
30\end{array}$ & $\begin{array}{l}4.5 \\
4.0\end{array}$ & $\begin{array}{l}7.8 \\
7.4\end{array}$ & $\begin{array}{l}4.0 \\
4.0\end{array}$ \\
\hline
\end{tabular}


TAELE 21.--WATER-QUALITY DATA FOR MINES IN SHALLOW AQUIFER--CONTINUED

\begin{tabular}{|c|c|c|c|c|c|c|c|c|c|c|c|c|}
\hline $\begin{array}{l}\text { MAP } \\
\text { NUM- } \\
\text { BER } \\
\text { IIN } \\
\text { FIG- } \\
\text { URE 31 }\end{array}$ & STATION NUMBER & $\begin{array}{c}\text { DATE } \\
\text { CF } \\
\text { SAMPLE }\end{array}$ & $\begin{array}{l}\text { ALKA- } \\
\text { LINITY } \\
\text { FIELD } \\
\text { (MG/L } \\
\text { AS } \\
\text { CACOS) }\end{array}$ & $\begin{array}{l}\text { SULFATE } \\
\text { DIS- } \\
\text { SOLVED } \\
\text { (MG/L } \\
\text { AS SO4) }\end{array}$ & $\begin{array}{l}\text { CHLO- } \\
\text { RIDE, } \\
\text { DIS- } \\
\text { SOLVEO } \\
\text { (MG/L } \\
\text { AS CL) }\end{array}$ & $\begin{array}{l}\text { FLUO- } \\
\text { RIDE, } \\
\text { DIS- } \\
\text { SOLVED } \\
\text { (MGIL } \\
\text { AS F) }\end{array}$ & $\begin{array}{l}\text { SILICA, } \\
\text { DIS- } \\
\text { SOLVED } \\
\text { (MG/L } \\
\text { AS } \\
\text { SIOZ) }\end{array}$ & $\begin{array}{l}\text { RESIDUE } \\
\text { AT } 180 \\
\text { DEG. C } \\
\text { OIS- } \\
\text { SOLVED } \\
\text { (MG/L) }\end{array}$ & $\begin{array}{l}\text { GEN, } \\
\text { NITRATE } \\
\text { DIS- } \\
\text { SCLVEO } \\
\text { (MG/L } \\
\text { AS N) }\end{array}$ & $\begin{array}{l}\text { ARSENIC } \\
\text { DIS- } \\
\text { SOLVED } \\
\text { (UG/L } \\
\text { AS AS) }\end{array}$ & $\begin{array}{l}\text { BARIUM, } \\
\text { OIS- } \\
\text { SOLVED } \\
\text { (UG/L } \\
\text { AS BA) }\end{array}$ & $\begin{array}{l}\text { CADMIUM } \\
\text { DIS- } \\
\text { SOLVED } \\
\text { CUG/L } \\
\text { AS CD) }\end{array}$ \\
\hline 10 & $\begin{array}{l}370108094455201 \\
370213094472501\end{array}$ & $\begin{array}{l}81-12-08 \\
81-12-08 \\
81-12-09 \\
81-12-08 \\
81-11-20\end{array}$ & $260^{--}$ & $450^{--}$ & 25 & $\begin{array}{l}-- \\
-- \\
04 \\
--\end{array}$ & $11^{--}$ & $\begin{array}{l}-- \\
\overline{--} \\
380\end{array}$ & $\begin{array}{l}-- \\
-- \\
--\end{array}$ & $\begin{array}{l}-- \\
-- \\
--\end{array}$ & $\begin{array}{c}-- \\
-- \\
100 \\
--\end{array}$ & $\begin{array}{r}-- \\
-- \\
-- \\
--\end{array}$ \\
\hline & & $\begin{array}{l}81-11-20 \\
81-11-20 \\
81-11-20 \\
81-11-20 \\
81-11-20\end{array}$ & 120 & 500 & $\begin{array}{c}<5.0 \\
=- \\
-- \\
--\end{array}$ & $\begin{array}{l}-- \\
-- \\
--\end{array}$ & $14=$ & $\begin{array}{l}834 \\
-- \\
\overline{--} \\
--\end{array}$ & $\begin{array}{l}.20 \\
-- \\
-- \\
--\end{array}$ & $\begin{array}{l}0 \\
-- \\
--\end{array}$ & $\begin{array}{l}0 \\
-- \\
-- \\
--\end{array}$ & $\begin{array}{l}4 \\
-- \\
-- \\
--\end{array}$ \\
\hline & & $\begin{array}{l}81-11-20 \\
81-11-20 \\
81-11-20 \\
82-03-16 \\
82-03-16\end{array}$ & $140^{--}$ & $630^{--}$ & $10^{--}$ & $\begin{array}{l}-- \\
-- \\
-2 \\
--\end{array}$ & $11^{--}$ & $\begin{array}{l}-- \\
-- \\
-- \\
--\end{array}$ & $\begin{array}{l}-- \\
-- \\
-- \\
--\end{array}$ & $\begin{array}{l}-- \\
-\overline{0} \\
--\end{array}$ & $\begin{array}{l}-- \\
-- \\
0 \\
--\end{array}$ & $\begin{array}{r}-- \\
-- \\
--\end{array}$ \\
\hline $\begin{array}{l}13 \\
1,4\end{array}$ & $\begin{array}{l}370056094511101 \\
370146094465401\end{array}$ & $\begin{array}{l}82-03-16 \\
32-03-16 \\
82-03-16 \\
81-11-19 \\
82-03-17\end{array}$ & $\begin{array}{l}150 \\
150^{--} \\
180 \\
5.0\end{array}$ & $\begin{array}{c}640 \\
640 \\
480 \\
1500\end{array}$ & $\begin{array}{l}9.2 \\
-2.7 \\
85.7 \\
33\end{array}$ & $\begin{array}{l}.2 \\
-2 \\
1.3\end{array}$ & $\begin{array}{l}11 \\
11 \\
14 \\
18\end{array}$ & $\begin{array}{c}-- \\
-- \\
363 \\
--\end{array}$ & $\begin{array}{l}-- \\
-- \\
.00 \\
--\end{array}$ & $\begin{array}{l}10 \\
-- \\
10 \\
10 \\
20\end{array}$ & $\begin{array}{r}-0 \\
100 \\
100 \\
0\end{array}$ & $\begin{array}{r}4 \\
-- \\
5 \\
1 \\
5\end{array}$ \\
\hline 15 & 370109094510701 & $\begin{array}{l}82-03-17 \\
82-03-17 \\
82-03-17 \\
82-03-17 \\
81-08-13\end{array}$ & $131^{--}$ & $1700^{--}$ & $\begin{array}{c}-- \\
36 \\
2.0\end{array}$ & $\begin{array}{l}-- \\
-- \\
1.2 \\
.7\end{array}$ & $17^{--}$ & $\begin{array}{l}=- \\
=- \\
=- \\
350\end{array}$ & $\begin{array}{l}-- \\
\overline{--} \\
\overline{-1}\end{array}$ & $\begin{array}{r}-- \\
-- \\
-- \\
0\end{array}$ & $\begin{array}{l}-- \\
-- \\
0 \\
0\end{array}$ & $\begin{array}{r}-- \\
-- \\
2 \\
0\end{array}$ \\
\hline 16 & 3701,20094505301 & $\begin{array}{l}81-11-19 \\
82-03-17 \\
82-03-17 \\
82-03-17 \\
82-03-17\end{array}$ & $\begin{array}{r}86 \\
120 \\
-- \\
--\end{array}$ & $\begin{array}{r}180 \\
260 \\
=- \\
--\end{array}$ & $\begin{array}{r}<5.0 \\
4.6 \\
-0 \\
-- \\
--\end{array}$ & $\begin{array}{l}-- \\
0 \\
-- \\
--\end{array}$ & $\begin{array}{r}9.0 \\
7.0 \\
-- \\
--\end{array}$ & $\begin{array}{r}351 \\
534 \\
-- \\
-- \\
--\end{array}$ & $\begin{array}{l}.20 \\
-- \\
-- \\
--\end{array}$ & $\begin{array}{l}-- \\
0 \\
-- \\
--\end{array}$ & $\begin{array}{r}-- \\
100 \\
--\end{array}$ & $\begin{array}{l}-- \\
12 \\
-- \\
--\end{array}$ \\
\hline 17 & 370232094460101 & $\begin{array}{l}82-03-18 \\
82-03-18 \\
82-03-18 \\
82-03-18\end{array}$ & $290^{84}-$ & $1000^{460}$ & $\begin{array}{r}4.2 \\
-=-8 \\
8.8\end{array}$ & $\begin{array}{r}.7 \\
1.7 \\
-.\end{array}$ & $\begin{array}{r}8.0 \\
8.0 \\
-.\end{array}$ & $\begin{array}{c}736 \\
-- \\
--\end{array}$ & $\begin{array}{l}-- \\
-- \\
--\end{array}$ & $\begin{array}{l}0 \\
-- \\
--\end{array}$ & $\begin{array}{r}0 \\
-- \\
100 \\
--\end{array}$ & $\begin{array}{r}5 \\
-- \\
58 \\
--\end{array}$ \\
\hline 23 & 370447094381,301 & $\begin{array}{l}81-C 8-11 \\
82-03-15\end{array}$ & $\begin{array}{l}24 \\
20\end{array}$ & $\begin{array}{l}140 \\
140\end{array}$ & $\begin{array}{l}12 \\
13\end{array}$ & $\begin{array}{l}.2 \\
.2\end{array}$ & $\begin{array}{l}8.0 \\
9.0\end{array}$ & $27 \overline{5}$ & .90 & $\begin{array}{l}0 \\
0\end{array}$ & $\begin{array}{r}0 \\
100\end{array}$ & $\begin{array}{l}220 \\
200\end{array}$ \\
\hline
\end{tabular}


TABLE 21.--WATER-QUALITY DATA FOR MINES IN SHALLOW AQUIFER--CONTINUED

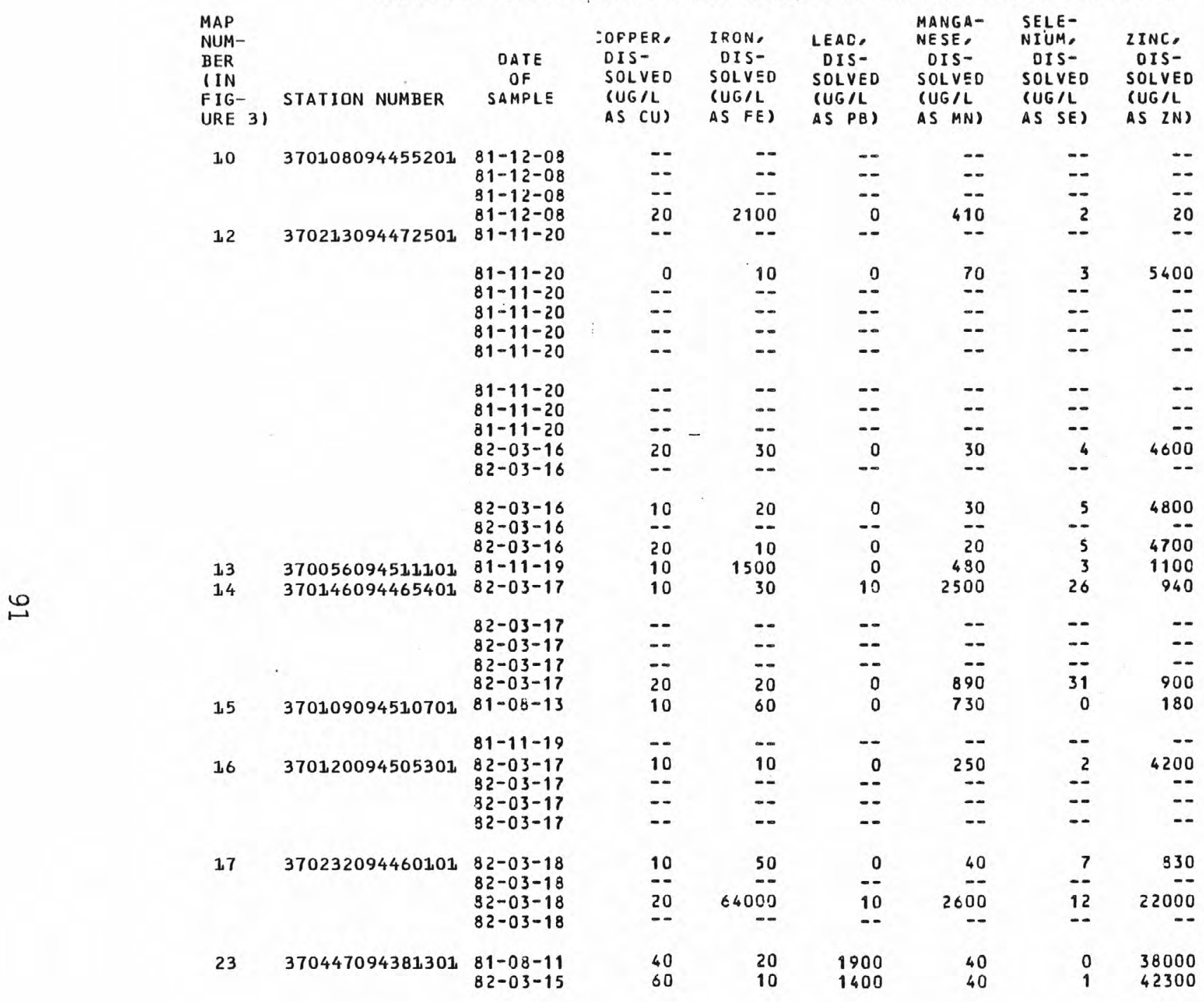


TABLE 21.--WATER-QUALITY DATA FOR MINES IN SHALLOW AQUIFER--CONTINUED

\begin{tabular}{|c|c|c|c|c|c|c|c|c|c|c|c|c|}
\hline $\begin{array}{l}\text { MAP } \\
\text { NUM- } \\
\text { BER } \\
\text { LF IIG- }\end{array}$ & STATICN NUMBER & $\begin{array}{c}\text { DATE } \\
\text { OF } \\
\text { SAMPLE }\end{array}$ & $\begin{array}{l}\text { DEPTH } \\
\text { BELOW } \\
\text { LAND } \\
\text { SURFACE } \\
\text { (WATER } \\
\text { LEVEL) } \\
\text { (FEET) }\end{array}$ & $\begin{array}{l}\text { SAM- } \\
\text { PLING } \\
\text { DEPTH } \\
\text { (FEET) }\end{array}$ & $\begin{array}{l}\text { SPE- } \\
\text { CIFIC } \\
\text { CON- } \\
\text { DUCT- } \\
\text { ANCE } \\
\text { (UMHOS) }\end{array}$ & $\begin{array}{l}\text { PH } \\
\text { (STAND- } \\
\text { ARD } \\
\text { UNITS) }\end{array}$ & $\begin{array}{l}\text { TEMPER- } \\
\text { ATURE } \\
\text { (DEG C }\end{array}$ & $\begin{array}{l}\text { OXYGEN, } \\
\text { DIS- } \\
\text { SOLVED } \\
\text { (MG/L) }\end{array}$ & $\begin{array}{l}\text { CALCIUM } \\
\text { OIS- } \\
\text { SOLVED } \\
\text { (MG/L } \\
\text { AS (A) }\end{array}$ & $\begin{array}{l}\text { MAGNE- } \\
\text { SIUM, } \\
\text { OIS- } \\
\text { SOLVED } \\
\text { (MG/L } \\
\text { AS MG) }\end{array}$ & $\begin{array}{l}\text { SODIUM, } \\
\text { OIS- } \\
\text { SCLVEC } \\
\text { (MGIL } \\
\text { AS NA) }\end{array}$ & $\begin{array}{l}\text { POTAS- } \\
\text { SIUM, } \\
\text { DIS- } \\
\text { SOLVED } \\
\text { (MG/L } \\
\text { AS K) }\end{array}$ \\
\hline $\begin{array}{l}\text { URE 31 } \\
23 \\
24 \\
28\end{array}$ & $\begin{array}{l}370447094381301 \\
370527094365701 \\
370520094365703\end{array}$ & $\begin{array}{l}82-03-15 \\
82-03-15 \\
81-03-12 \\
81-11-19 \\
81-03-12\end{array}$ & $\begin{array}{l}31.00 \\
30.00 \\
29.00 \\
11.00\end{array}$ & $\begin{array}{l}40.0 \\
32.0 \\
24.0 \\
30.0 \\
18.0\end{array}$ & $\begin{array}{l}360 \\
696 \\
415 \\
359\end{array}$ & $\begin{array}{l}6.2 \\
6.1 \\
5.2 \\
4.2 \\
3.7\end{array}$ & $\begin{array}{r}6.2 \\
12.5 \\
15.0 \\
-.- \\
15.0\end{array}$ & $\begin{array}{l}-- \\
-- \\
.2 \\
--0 \\
.6\end{array}$ & $\begin{array}{l}32 \\
50 \\
64 \\
26\end{array}$ & $\begin{array}{l}-. \\
5.0 \\
4.0 \\
2.5 \\
2.0\end{array}$ & $\begin{array}{l}3.1 \\
3.9 \\
3.3 \\
3.8\end{array}$ & $\begin{array}{l}-- \\
5.0 \\
2.0 \\
2.0 \\
1.0\end{array}$ \\
\hline $\begin{array}{r}29 \\
30 \\
31\end{array}$ & $\begin{array}{l}370520094365702 \\
370441094371401 \\
370447094384701\end{array}$ & $\begin{array}{l}81-08-12 \\
81-08-13 \\
81-08-14 \\
32-03-16 \\
82-03-16\end{array}$ & $\begin{array}{r}9.00 \\
45.00 \\
24.00 \\
19.80 \\
--\end{array}$ & $\begin{array}{l}19.0 \\
48.0 \\
21.0 \\
25.0\end{array}$ & $\begin{array}{l}353 \\
245 \\
608 \\
078 \\
--\end{array}$ & $\begin{array}{l}3.9 \\
3.9 \\
4.7 \\
4.7 \\
4.7\end{array}$ & $\begin{array}{l}16.5 \\
21.0 \\
15.5 \\
14.5 \\
14.7\end{array}$ & $\begin{array}{r}1.2 \\
5.4 \\
-- \\
5.2 \\
.5\end{array}$ & $\begin{array}{l}25 \\
13 \\
64 \\
80 \\
-\end{array}$ & $\begin{array}{r}2.0 \\
2.0 \\
9.5 \\
12 \\
-.\end{array}$ & $\begin{array}{r}3.7 \\
.9 \\
4.9 \\
5.3 \\
.-\end{array}$ & $\begin{array}{l}1.0 \\
.9 \\
2.0 \\
2.0 \\
.-\end{array}$ \\
\hline $\begin{array}{l}33 \\
34\end{array}$ & $\begin{array}{l}370448094385501 \\
370415094381301\end{array}$ & $\begin{array}{l}82-03-16 \\
82-03-16 \\
82-03-16 \\
81-08-14 \\
81-08-12\end{array}$ & $\begin{array}{r}-- \\
14.00 \\
3.00\end{array}$ & $\begin{array}{l}30.0 \\
35.0 \\
40.0 \\
13.0\end{array}$ & $\begin{array}{l}-- \\
-- \\
605 \\
459 \\
420\end{array}$ & $\begin{array}{l}4.7 \\
4.7 \\
4.7 \\
3.6 \\
3.6\end{array}$ & $\begin{array}{l}14.6 \\
14.6 \\
14.5 \\
17.0 \\
27.0\end{array}$ & $\begin{array}{r}.2 \\
.2 \\
.1 \\
1.8 \\
5.4\end{array}$ & $\begin{array}{l}74^{--} \\
45 \\
43\end{array}$ & $\begin{array}{l}11^{--} \\
6.0 \\
3.5\end{array}$ & $\begin{array}{l}-.- \\
5.1 \\
4.4 \\
6.8\end{array}$ & $\begin{array}{r}-- \\
-- \\
2.0 \\
2.0 \\
3.0\end{array}$ \\
\hline
\end{tabular}

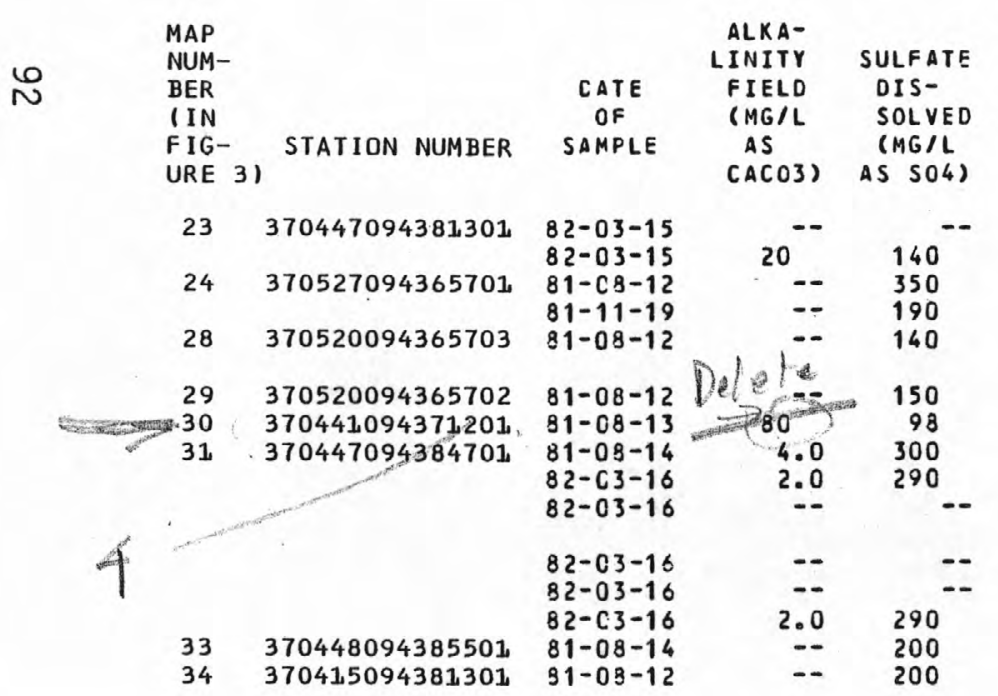

CHLO-
RIDE,
DIS-
SCLVEO
(NGIL
AS CL)

13
2.0
$<5.0$
3.0
2.0
1.0
4.0
6.9
.-
.-
.-
0.0
4.0
2.0

\begin{tabular}{|c|c|}
\hline $\begin{array}{l}\text { FLUO- } \\
\text { RIDE, } \\
\text { DIS- } \\
\text { SOLVEO } \\
\text { (MGIL } \\
\text { AS F) }\end{array}$ & $\begin{array}{l}\text { SILICA } \\
\text { OIS- } \\
\text { SOLVE } \\
\text { (MG/L } \\
\text { AS } \\
\text { SIO2) }\end{array}$ \\
\hline $\begin{array}{l}-- \\
.2 \\
.0 \\
- \\
.1\end{array}$ & $\begin{array}{l}19 \\
14 \\
14\end{array}$ \\
\hline $\begin{array}{l}.1 \\
.2 \\
.4 \\
.6\end{array}$ & $\begin{array}{l}14 \\
21 \\
19 \\
17\end{array}$ \\
\hline- & \\
\hline $\begin{array}{l}.6 \\
.3 \\
.2\end{array}$ & $\begin{array}{l}17 \\
16 \\
24\end{array}$ \\
\hline
\end{tabular}

SOLIDS,
RESIDUE
AT 180

NITRO-

AT 180 NITRATE ARSENIC BARIUM, CAOMIUM DEG. C DISDIS(MG/L) SOLVED (MG)

DIS-
DISDIS AS ND

(UG/L (UGIL SOLVED AS (D)

$\begin{array}{ccr}9.0 & 351 & -- \\ 14 & -- & .10 \\ 14 & 285 & 1.20 \\ 14 & -- & .70 \\ 14 & -- & .60 \\ 21 & -- & 1.20 \\ 19 & -- & .10 \\ 17 & 490 & -- \\ -- & -- & -- \\ -- & -- & -- \\ 17 & -- & -- \\ 16 & 490 & -- \\ 24 & -- & .10 \\ & -- & .20\end{array}$

$$
\begin{array}{r}
-- \\
0 \\
\mathbf{C} \\
0 \\
0 \\
0 \\
0 \\
0 \\
0 \\
-- \\
-- \\
-- \\
0 \\
0 \\
0
\end{array}
$$$$
\begin{array}{r}
-- \\
100 \\
0 \\
0 \\
0 \\
0 \\
0 \\
0 \\
0 \\
-- \\
-- \\
-- \\
0 \\
0 \\
0
\end{array}
$$

-230 40
340 340 320 20
150 150 
TABLE 21.--WATER-QUALITY DATA FOR MINES IN SHALLOW AQUIFER--CONTINUED

MAP

NUM

BER

I IN

FIG-

STATION NUMBER

$23 \quad 370447094381301$

$24 \quad 370527094365701$

$28 \quad 370520094365703$

370520094365702 370441094371401 370447094384701

$82-03-16$
$82-03-16$

$82-03-16$
$82-03-16$ $82-03-16$

$33 \quad 370448094385501$

$370415094381301 \quad 81-09-12$

OF
SAMPLE

$82-03-15$

$81-03-12$

$81-11-19$

COPPER
DIS-
SOLVE
CUG IL
AS CU
-
1
4
5
1
4
-
-
5
5

IRON,
DIS-
SCLVED
SUG/L
AS FES
-
20
58000
40
60
50
90
2000
60
-
-
--
80
190
20

IRON.
DIS-

LEAD,
OIS-

NESE。

SELE-

NIUM,

DIS- DIS-

SOLVED

OLVEO

SOLVED

(UG/L (UG/L

SOLVED

S FES AS PB)

AS MN)

$-$

$--$

) $\quad 2 N$

$\begin{array}{rr}20 & 900 \\ 500 & 10\end{array}$

60

0
250

60
680

240

180

$-2$

44000

72000

320

40000

240

$\begin{array}{lll}180 & 1 & 39000\end{array}$

$\begin{array}{lll}170 & 0 & 36000 \\ 510 & 2 & 60000\end{array}$

$\begin{array}{lll}510 & 2 & 60000 \\ 660 & 3 & 79000\end{array}$ 380 
TABLE 22.-- WATER-QUALITY DATA FOR HELLS IN DEEP AQUIFER

(Values given in either feetenicromhos per centimeter at 25 C(umhos),pH units,

degrees Celsius(deg ( ), milligrams per liter(mg/L), or micrograms per liter(ug/L)]

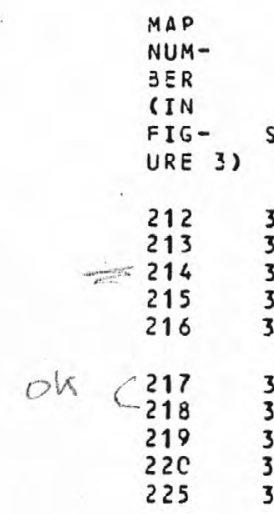

\begin{tabular}{|c|c|}
\hline STATION NUMBER & $\begin{array}{c}\text { DATE } \\
\text { OF } \\
\text { SAMPLE }\end{array}$ \\
\hline $\begin{array}{l}371035094501301 \\
370437094475501 \\
370659094403601 \\
370421094381301 \\
371010094423201\end{array}$ & $\begin{array}{l}81-07-23 \\
81-07-23 \\
81-07-31 \\
81-07-30 \\
81-07-30\end{array}$ \\
\hline $\begin{array}{l}365900094500001 \\
365600094530002 \\
370244094443001 \\
370159074443001 \\
370215094440301\end{array}$ & $\begin{array}{l}81-07-23 \\
81-07-23 \\
81-07-22 \\
81-07-23 \\
81-07-22\end{array}$ \\
\hline
\end{tabular}

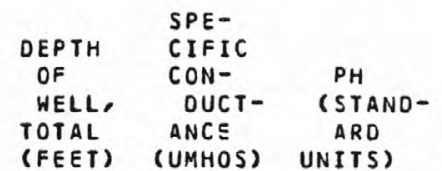

TEMPER-
ATURE
(DEG C)

$\begin{array}{rrr}-- & 1120 & 6.9 \\ -- & 1060 & 7.9 \\ 901 & 330 & 7.6 \\ 1189 & 470 & 7.6 \\ 900 & 480 & 7.5 \\ 1077 & 425 & 7.9 \\ 1115 & 340 & 7.7 \\ -- & 1220 & 7.6 \\ 1267 & 970 & 7.2 \\ 1094 & 590 & 7.6\end{array}$

\section{5}

CALCIUM

MAGNE-

ALCIUM SIUM, SOOIUM,
OIS-

SOLVEO

AS MG) AS NA)

$\begin{array}{cc}\text { POTAS- } & \text { ALKA- } \\ \text { SIUM, } & \text { LINITY } \\ \text { OIS- } & \text { FIELD } \\ \text { SOLVED } & \text { (MG/L } \\ \text { (MGIL } & \text { AS } \\ \text { AS K) } & \text { CACO3) } \\ & \\ 8.0 & 260 \\ 6.0 & 160 \\ 3.0 & 120 \\ 2.0 & \\ 3.0 & 200 \\ & \\ 2.0 & 120 \\ 3.0 & 120 \\ 5.0 & 140 \\ 4.0 & 170 \\ 3.0 & 150\end{array}$

SULFATE

OIS-

(MOLVEO

Gross

Radican

AS (A)

$\begin{array}{rr}25 & 130 \\ 21 & 120 \\ 13 & 19 \\ 18 & 14 \\ 20 & 19 \\ 18 & 12 \\ 12 & 14 \\ 13 & 150 \\ 31 & 42 \\ 20 & 31\end{array}$

ค

NUM-

BER

FIG-

URE 3)

STATION NUMBER

CATE

OF
SAMPLE

CHLO-

\begin{tabular}{l} 
FLUO- \\
RIDICA, \\
OIS- \\
OIS- \\
SOLVED SCLVED \\
(MGIL \\
(NGIL \\
AS F) AS \\
\hline SIOZ)
\end{tabular}

SOLIDS, NITRO-

RIDE,

DIS-

(MGIL

AS CL)

SI02)

RESIDUE

GEN,

DEG NITRAT

ARSENIC BARIUM,

CADMIUM COPPER, S SO4)

$21.2371,035094501301,81-07-23$ $370437094475501 \quad 81-07-23$ $370659094403601 \quad 81-07-31$ $370421094381301,81-67-30$

140

200

$370421094381301,81-07-30$

1.410

DIS-

DIS-
SOLVED

SOLVED SOLVED

DIS-

DIS-

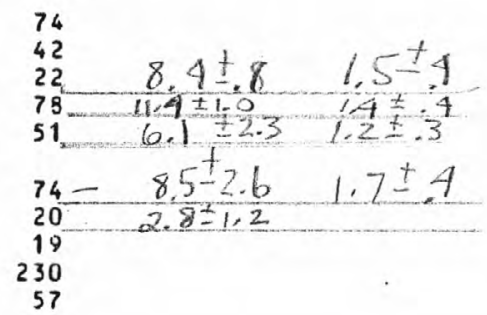

$365900094500001 \quad 81-07-23$ $365600094530002 \quad 81-07-23$ $370244094443001 \quad 81-C 7-22$ $370159094443001 \quad 81-07-23$ $37021509444030181-07-22$

10
9.0
9.0
9.0
9.0
8.0
8.0
9.0
9.0
9.0

$\begin{array}{ll}593 & .00 \\ 532 & .00 \\ 175 & .10 \\ 268 & .10 \\ 267 & .00 \\ 235 & .00 \\ 167 & .00 \\ 577 & .00 \\ 562 & .00 \\ 294 & .00\end{array}$

(UG/L (UG/L

SOLVED

IRON,

DOLS-

AS CD) AS CU) (UG/L

$$
\begin{aligned}
& 0 \\
& 0 \\
& 0 \\
& 0 \\
& 0 \\
& 0 \\
& 0 \\
& 0 \\
& 0 \\
& 0
\end{aligned}
$$$$
\begin{aligned}
& 100 \\
& 200
\end{aligned}
$$$$
\begin{aligned}
& 200 \\
& 100 \\
& 200
\end{aligned}
$$$$
\text { 0 }
$$$$
100
$$

$\begin{array}{rrr}1 & 0 & 40 \\ 3 & 10 & 30 \\ 0 & 0 & 10 \\ 1 & 0 & 40 \\ 3 & 0 & 60 \\ 3 & 0 & 330 \\ 3 & 0 & 70 \\ 0 & 10 & 1700 \\ 3 & 10 & 1400 \\ 1 & 10 & 80 \\ 0 & & \end{array}$


TABLE 22.--WATER-QUALITY DATA FOF WELLS IN DEEP AQUIFER--CONTINUED

MAP

NUM-

(IN

FIG-

$212371035094501301 \quad 81-07-23$

$213 \quad 370437094475501 \quad 81-07-23$

$214 \quad 370659094403601 \quad 81-07-31$

$370421094381,301,81-07-30$

$\begin{array}{ll}370421,094381,301, & 81-07-30 \\ 371010094423201 & 81-07-30\end{array}$

$365900094500001 \quad 31-07-23$

$365600094530002 \quad 81-07-30$

$370244094443001 \quad 81-07-22$

$370159094443001,81-07-23$

$37021,5094440301,81-07-22$
MANGA-

LEAO

OIS-

SUG

MESE,

SOIS-

CUG

S

SELE-

IINC,

DIS-

(UGIL

AS SEJ

DIS-

SCLVED

AS IN)

0
0
0
0
0
0
0
0
0
0

10
10
10
10
0
10
10
20
30
10

0
1
1
0
1

0
0
10
100
20
0
100
70
70
10 
TABLE 23.-- WATER-QUALITY DATA FOR SURFACE-WATER SITES

(Values given in either cubic feet per second $\left(\mathrm{ft}^{2} / \mathrm{s}\right)$, micromhos per centimeter at 25 C(umhos), pH unitsodegrees Celsius(deg C),milligrams per liter(mg/L),

or micrograms per liter(ug/L). E denotes estimated value]

MAP

NUM-

SER

FIG- STATICN NUMBER

07186000
371042094383700
370758094373900

370626094395400

370428094415300

07187600

07186480
370740094372900

370545094355900

370527094352700

370522094370900

370527094370500

370533094370500

370501094380500

370408094333000 37050309438220

370454094390400

370527094401100

370448094400300

370447094332200

370553094333800

370159094452300

370225094442600

370225094442600

370225094454000
370219094463900

370219094463900

360246094474000

STREAM-
FLOW.
INSTAN-

( $F T^{3} / S$ )

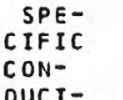

CON-

T- (STANO
ARD

(UMHOS) UNITS)

$211 \quad 301$

228

222

\section{9}

7.9
7.9

7.5

$81-08-11$

--

344

393
355

7.3

504

$81-08-14 \quad 46$

$81-08-14$
$81-08-12$

$81-06-16$

.09

$32^{.09}$

513
725

400

7.2
7.8

7.8

7.2

$--$

260

7.5

7.2
6.0

6.0

$81-08-12$

$81-08-1$

$81-08-12$

$81-08-12$

$81-06-16$

$81-08-12$

1.27
.03

.27
.03
1.7

280
768

248
387

$E .05$
.12

$81^{.12}$

15

81-06-16

$1-08-12$

(1)

14.7

5.0
.41

$<.01$

$2-03-16$

$82-03-17$
$81-08-13$

$81-06-16$

81-06-17

$<.50$

11

$81-08-13$

$1-08-13$

$1-08-13$

$81-06-17$

.25

.05
$<.04$

39.9
190

6.2
7.2

7.1
4.6
7.2

0.3

6.9

7.2
7.0

7.0
7.9

7.9
4.6

4.7

7.3

7.3

7.4
7.4

6.9
0.9

6.9

7.2
7.5

275 $\begin{array}{lc} & \\ \text { OXYGEN, } & \text { CALCI } \\ \text { TEMPER- } & \text { DIS- } \\ \text { ATURE } & \text { SOLVED } \\ \text { (DEG C) } & \text { (MG/L) }\end{array}$

CALCIUM
DIS-

MAGNE-

SIUM, SOUIUM,

OIS- OIS-

$\begin{array}{rrr}25.0 & 7.9 & 52 \\ 25.5 & 7.8 & -- \\ 26.0 & 8.2 & -- \\ 25.5 & -- & -- \\ 26.5 & -- & 52\end{array}$

AS MG)

(MG/L

POTAS-

DIS- FIELD

SCLVED (MG/L

$\begin{array}{cl}(M G / L & A S \\ A S K) & C A C 03)\end{array}$

27.5

26.0

24.0
23.0

23.0

22.0
25.0

23.5
21.5

21.5

20.5

23.0

27.0
28.0

22.5

30.0

14.0

24.5

30.0

28.0

30.0

15.5
12.5

25.0

21.0

$\begin{array}{cc}7.5 & 89^{--} \\ -- & -0\end{array}$

--

66

$41^{-}$

5.2
4.0
3.5

4.0
3.5
4.0

0.5

$0.5 \quad 3.0 \quad 120$

$\begin{array}{lll}8.1 & 3.0 & 120 \\ 9.9 & 3.0 & 120\end{array}$

3.57

$\begin{array}{ll}4.5 & 13 \\ 6.0 & 31\end{array}$

$5.5 \quad 6.7$

4.5

5.1

$8.5 \quad 15$

8.1000

9.5

100
43
59

2.5

15

62

7.9

62
41

86
57

3.5
3.0
7.5

8.6

57

11.

71
33
14

8.0

0.0
6.5

8.5

14

11
2.5

48
58
630

2.0

24.0

25.5

26.0

23.5

21.0

26.0

(2)

23
22
25
-

3.5
3.5
5.5
.-
-- 
TABLE 23.--WATER-QUALITY DATA FOR SURFACE-WATER SITES--CONTINUED

\begin{tabular}{|c|c|c|c|c|c|c|c|c|c|c|c|c|}
\hline $\begin{array}{l}\text { MAP } \\
\text { NUM- } \\
\text { BER } \\
\text { I IN } \\
\text { FIG- }\end{array}$ & STATION NUMBER & $\begin{array}{c}\text { CATE } \\
\text { CF } \\
\text { SAMPLE }\end{array}$ & $\begin{array}{l}\text { SULFATE } \\
\text { DIS- } \\
\text { SOLVED } \\
\text { (MG/L }\end{array}$ & $\begin{array}{l}\text { CHLO- } \\
\text { RIDE. } \\
\text { OIS- } \\
\text { SOLVED } \\
\text { CMGIL }\end{array}$ & $\begin{array}{l}\text { FLUO- } \\
\text { RIDE, } \\
\text { DIS- } \\
\text { SCLVED } \\
\text { IMGIL }\end{array}$ & $\begin{array}{l}\text { SILICA. } \\
\text { OIS- } \\
\text { SOLVED } \\
\text { CMG/L } \\
\text { AS }\end{array}$ & $\begin{array}{l}\text { SOLIDS } \\
\text { RESIDUE } \\
\text { AT } 180 \\
\text { CEG. C } \\
\text { DIS- } \\
\text { SOLVED }\end{array}$ & $\begin{array}{l}\text { NITRO- } \\
\text { GEN } \\
\text { NITRATE } \\
\text { OIS- } \\
\text { SOLVED } \\
\text { (MG /L }\end{array}$ & $\begin{array}{l}\text { ARSENIC } \\
\text { DIS- } \\
\text { SCLVED } \\
\text { CUGIL }\end{array}$ & $\begin{array}{l}\text { SARIUM, } \\
\text { DIS- } \\
\text { SOLVED } \\
\text { (UGIL }\end{array}$ & $\begin{array}{l}\text { CADMIUM } \\
\text { OIS- } \\
\text { SOLVED } \\
\text { CUG/L }\end{array}$ & $\begin{array}{l}\text { COPPER, } \\
\text { DIS- } \\
\text { SOLVED } \\
\text { (UGIL }\end{array}$ \\
\hline URE 41 & ) & & AS S(4) & AS $(L)$ & AS FI & $5(02)$ & $(M G / L)$. & AS $N$ ) & $A S$ AS) & $A S$ BA) & AS $(D)$ & AS (U) \\
\hline $\begin{array}{l}1 \\
2 \\
3 \\
4 \\
5\end{array}$ & $\begin{array}{r}07186000 \\
371.042094383700 \\
370758094373900 \\
370626094395400 \\
370428094415300\end{array}$ & $\begin{array}{l}81-08-11 \\
81-08-11 \\
81-08-11 \\
81-08-11 \\
81-08-11\end{array}$ & $\begin{array}{l}16 \\
21 \\
33 \\
44 \\
48\end{array}$ & $\begin{array}{r}7.0 \\
9.0 \\
9.0 \\
11 \\
8.0\end{array}$ & $\begin{array}{l}= \\
= \\
= \\
=\end{array}$ & $\begin{array}{l}10 \\
10 \\
9.0 \\
8.0 \\
10\end{array}$ & $\begin{array}{l}= \\
=- \\
= \\
=\end{array}$ & $\begin{array}{l}2.00 \\
1.60 \\
3.30 \\
3.90 \\
2.40\end{array}$ & $\begin{array}{l}=- \\
\overline{--} \\
\cdots\end{array}$ & $\begin{array}{r}100 \\
100 \\
0 \\
0 \\
0\end{array}$ & $\begin{array}{l}0 \\
0 \\
0 \\
0 \\
0\end{array}$ & $\begin{array}{l}0 \\
0 \\
0 \\
0 \\
0\end{array}$ \\
\hline $\begin{array}{r}6 \\
7 \\
8 \\
9 \\
10\end{array}$ & $\begin{array}{r}071,87600 \\
071,86480 \\
370740094372900 \\
37054509435500 \\
370527094352700\end{array}$ & $\begin{array}{l}81-08-11 \\
81-08-14 \\
81-03-14 \\
81-08-12 \\
81-06-16 \\
81-08-12\end{array}$ & $\begin{array}{r}34 \\
100 \\
150 \\
100 \\
55 \\
50\end{array}$ & $\begin{array}{l}8.0 \\
11 \\
36 \\
2.0 \\
5.0 \\
2.0\end{array}$ & $\begin{array}{l}-- \\
-\infty \\
-- \\
=- \\
=-\end{array}$ & $\begin{array}{r}10 \\
8.0 \\
9.0 \\
11 \\
6.0\end{array}$ & $\begin{array}{l}=- \\
=- \\
=- \\
=-\end{array}$ & $\begin{array}{l}2.00 \\
7.40 \\
1.20 \\
.00 \\
.22 \\
.00\end{array}$ & $\begin{array}{l}-- \\
-- \\
=- \\
-- \\
--\end{array}$ & $\begin{array}{r}100 \\
0 \\
0 \\
100 \\
0 \\
100\end{array}$ & $\begin{array}{l}0 \\
0 \\
0 \\
0 \\
0 \\
0\end{array}$ & $\begin{array}{r}20 \\
0 \\
0 \\
0 \\
0 \\
0\end{array}$ \\
\hline $\begin{array}{l}1,2 \\
1,3 \\
14\end{array}$ & $\begin{array}{c}37052209437900 \\
3705270943705 \cdot 00 \\
3705330943705100 \\
370501094380500\end{array}$ & $\begin{array}{l}81-06-16 \\
81-08-12 \\
81-08-12 \\
81-08-12 \\
81-06-16\end{array}$ & $\begin{array}{r}80 \\
260 \\
32 \\
110 \\
53\end{array}$ & $\begin{array}{l}5.0 \\
15 \\
3.0 \\
3.0 \\
5.0\end{array}$ & $\begin{array}{l}-- \\
-- \\
--\end{array}$ & $\begin{array}{c}22^{--} \\
9.0 \\
10^{-} \\
--\end{array}$ & $\begin{array}{l}-- \\
-- \\
--\end{array}$ & $\begin{array}{l}4.90 \\
1.10 \\
2.10 \\
1.20\end{array}$ & $\begin{array}{l}-- \\
-- \\
--\end{array}$ & $\begin{array}{r}100 \\
0 \\
0 \\
0 \\
0\end{array}$ & $\begin{array}{r}0 \\
20 \\
20 \\
110 \\
60\end{array}$ & $\begin{array}{r}0 \\
0 \\
0 \\
0 \\
10\end{array}$ \\
\hline $\begin{array}{l}1,5 \\
1,6\end{array}$ & $\begin{array}{l}370408094383030 \\
370503094382250\end{array}$ & $\begin{array}{l}81-08-12 \\
81-08-12 \\
81-06-16 \\
81-08-12 \\
82-03-18\end{array}$ & $\begin{array}{r}50 \\
170 \\
86 \\
280 \\
120\end{array}$ & $\begin{array}{r}34 \\
2.0 \\
5.0 \\
14 \\
7.4\end{array}$ & $\begin{array}{l}-- \\
-- \\
-- \\
.2\end{array}$ & $\begin{array}{c}13 \\
23 \\
20 \\
9.0\end{array}$ & $\begin{array}{l}=- \\
-- \\
251\end{array}$ & $\begin{array}{r}2.10 \\
.30 \\
.41 \\
4.30 \\
-.-\end{array}$ & $\begin{array}{l}-- \\
-- \\
-- \\
0\end{array}$ & $\begin{array}{r}100 \\
0 \\
0 \\
0 \\
200\end{array}$ & $\begin{array}{r}60 \\
110 \\
70 \\
290 \\
110\end{array}$ & $\begin{array}{r}0 \\
10 \\
30 \\
50 \\
20\end{array}$ \\
\hline $\begin{array}{l}1,8 \\
1,9 \\
20\end{array}$ & $\begin{array}{l}370454094390400 \\
370527094401,100 \\
370448094400300 \\
370447094382200\end{array}$ & $\begin{array}{l}81-06-16 \\
81-08-12 \\
81-08-12 \\
81-08-12 \\
82-03-16\end{array}$ & $\begin{array}{r}77 \\
260 \\
240 \\
42 \\
140\end{array}$ & $\begin{array}{r}5.0 \\
7.0 \\
9.0 \\
31.0 \\
1.4\end{array}$ & $\begin{array}{l}-- \\
-- \\
-- \\
.2\end{array}$ & $\begin{array}{l}13^{--} \\
17 \\
15 \\
10\end{array}$ & $\begin{array}{l}-- \\
-- \\
230\end{array}$ & $\begin{array}{r}.10 \\
.10 \\
2.10 \\
.10 \\
.-\end{array}$ & $\begin{array}{l}-- \\
-- \\
-\overline{0}\end{array}$ & $\begin{array}{r}0 \\
0 \\
0 \\
100 \\
100\end{array}$ & $\begin{array}{r}40 \\
150 \\
170 \\
10 \\
360\end{array}$ & $\begin{array}{r}10 \\
0 \\
20 \\
10 \\
280\end{array}$ \\
\hline $\begin{array}{l}21 \\
22 \\
23 \\
24\end{array}$ & $\begin{array}{l}370553094383800 \\
370159094452300 \\
370159094450100 \\
370225094442600\end{array}$ & $\begin{array}{l}82-03-16 \\
82-03-17 \\
81-08-13 \\
81-06-16 \\
81-06-17\end{array}$ & $\begin{array}{c}140 \\
150 \\
1600 \\
55\end{array}$ & $\begin{array}{l}3.2 \\
5.5 \\
4.0 \\
-. \\
5.0\end{array}$ & $\begin{array}{r}.1 \\
1.4 \\
0 . \\
-. \\
-.\end{array}$ & $\begin{array}{l}10 \\
9.0 \\
9.0 \\
-. \\
--\end{array}$ & $\begin{array}{r}229 \\
291 \\
=- \\
=- \\
=-\end{array}$ & $\begin{array}{l}.- \\
.0 \\
.00 \\
.81 \\
.81\end{array}$ & $\begin{array}{r}0 \\
0 \\
-- \\
-- \\
--\end{array}$ & $\begin{array}{r}100 \\
0 \\
-- \\
100\end{array}$ & $\begin{array}{r}130 \\
110 \\
60 \\
-0 \\
0\end{array}$ & $\begin{array}{r}20 \\
0 \\
20 \\
-- \\
0\end{array}$ \\
\hline $\begin{array}{l}25 \\
26 \\
27 \\
28\end{array}$ & $\begin{array}{l}370225094454600 \\
37021,9094463900 \\
370246094474000 \\
365956094510400\end{array}$ & $\begin{array}{l}81-08-13 \\
81-08-13 \\
81-08-13 \\
81-06-17 \\
81-06-17\end{array}$ & $\begin{array}{l}37 \\
42 \\
43 \\
60 \\
86\end{array}$ & $\begin{array}{l}3.0 \\
3.0 \\
3.0 \\
5.0 \\
5.0\end{array}$ & $\begin{array}{l}=- \\
-\therefore \\
-\infty \\
-\infty\end{array}$ & $\begin{array}{r}7.0 \\
9.0 \\
8.0 \\
-.- \\
-.\end{array}$ & $\begin{array}{l}=- \\
=- \\
= \\
--\end{array}$ & $\begin{array}{r}.20 \\
.20 \\
.10 \\
1.30 \\
.93\end{array}$ & $\begin{array}{l}-- \\
-- \\
-- \\
--\end{array}$ & $\begin{array}{r}100 \\
0 \\
0 \\
0 \\
100\end{array}$ & $\begin{array}{r}0 \\
0 \\
0 \\
0 \\
10\end{array}$ & $\begin{array}{r}10 \\
10 \\
10 \\
0 \\
10\end{array}$ \\
\hline
\end{tabular}


TABLE 23.--WATER-QUALITY! DATA FOR SURFACE-WA'TER SITES--CONTINUED

MA

$\infty$

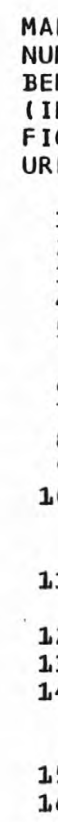

NUM-

BER

IG-

RE 4)

$\begin{array}{lrr}1 & 07186000 & 81-08-11 \\ 2 & 371042094383700 & 81-08-11 \\ 3 & 370758094373900 & 81-08-11 \\ 4 & 370626094395400 & 81-08-11 \\ 5 & 370428094415300 & 81-03-11\end{array}$

07187600

370740094372900

$370527094352700 \quad 81-06-16$
$81-05-12$

$370522094370900 \quad 81-06-16$

$81-08-12$

$370527094370500 \quad 81-08-12$

$370533094370500 \quad 81-08-12$

$370501094380500 \quad 81-06-16$

$81-08-12$

370408094383000

$81-08-12$

$81-08-12$

$82-03-18$

$\begin{array}{rrrr}17 & 370454094390400 & 81-06-16 & 50 \\ \vdots & & 81-08-12 & 10 \\ 18 & 370527094401100 & 81-08-12 & 10 \\ 19 & 370448094400300 & 81-08-12 & 20 \\ 20 & 370447094382200 & 82-03-16 & 20 \\ & & & \\ 21 & 370553094383800 & 82-03-16 & 30 \\ 22 & 370159094452300 & 82-03-17 & 30 \\ 23 & 370159094450100 & 81-08-13 & 30 \\ 24 & 370225094442600 & 81-06-16 & -- \\ & & 81-06-17 & 300 \\ & & & \\ 25 & 370225094454600 & 81-08-13 & 170 \\ 26 & 370219094463900 & 81-08-13 & 250 \\ 27 & 370246094474000 & 81-06-17 & 190 \\ 28 & 365956094510400 & 81-06-17 & 180\end{array}$

IRON
OIS -
SOLVED
(UG IL
AS FE )
10
10
10
10
20
10
20
10
20
20
80
20
100
100
50
0
20
50
10
90
60
0
0

MANGA-

NESE: NIUM,

LEAD,

DIS-

(UG/L

AS PB)

as MN)

OIS-

(UG/L

AS $2 N$

0
0
0
0
0
0
0
0
0
0
0

$$
\begin{array}{r}
20 \\
40 \\
60 \\
160 \\
28 \\
11 \\
40 \\
140 \\
80 \\
90 \\
4
\end{array}
$$$$
\begin{array}{rr}
= & 10 \\
-- & 0 \\
-- & 20 \\
-- & 10 \\
& 430 \\
-- & 90 \\
-- & 250 \\
-- & 160 \\
-- & 270 \\
-- & 630 \\
& 190
\end{array}
$$

0
0

0
0
0

0

200

0
0
0

120
860

10

0
40

$-$

$\begin{array}{rr}- & 940 \\ - & 1600 \\ - & 3500\end{array}$

$\begin{array}{rr}-- & 3500 \\ - & 15000\end{array}$

$\therefore \quad 15000$

10
540

540

350

- $\quad 5400$

--
--

78000
--

$0 \quad 130 \quad-17900$

130

370
1700

1700

90
230

-- $\quad 7900$

--
$--\quad 25000$
--

$\begin{array}{rr}-- & 280 \\ -1 & 65000\end{array}$

2700

30

30
90
140
--

\begin{tabular}{ll}
1 & 12300 \\
0 & 13600 \\
\hline
\end{tabular}

-- 12000

--

$\begin{array}{rrr}100 & -- & 140 \\ 40 & -- & 150 \\ 150 & -- & 280\end{array}$

$\begin{array}{rrr}350 & - & 180\end{array}$ 
TABLE 23.--WATER-QUALITY DATA FOR SURFACE-WATER SITES--CONTINUED

MAP

NUM-

( IN

FIG STATION NUMBER

URE 4)

$28 \quad 365955094510400$

$29 \quad 370107094510900$

$30 \quad 370226094505300$

$32 \quad 370001094510000$

MAP

NUM-

BER

FIG- STATION NUMBER

URE 4)

$28 \quad 365956094510400$

29370107094510900

30

$32 \quad 370001094510000$

\section{STREAM-}

STREAM-

INSTAN- DUCT-

ANEOUS ANCE

$\left(\mathrm{FT}^{3} / \mathrm{S}\right)$ (UMHOS)

$\begin{array}{ll}.08 & 1530 \\ 2.5 & 356 \\ <1.0 & 960 \\ 3.8 & 130 \\ E .05 & 792\end{array}$

792

$\begin{array}{cc}\text { DUIE } & \begin{array}{c}\text { SULATE } \\ \text { DIS- }\end{array} \\ \text { OF } & \begin{array}{r}\text { SOLVED } \\ \text { (MG/L } \\ \text { SAMPLE } \\ \text { AS SC4) }\end{array} \\ & \\ 81-08-13 & 910 \\ 82-03-18 & 97 \\ 81-08-13 & 410 \\ 81-06-17 & 32 \\ 82-03-18 & 270\end{array}$

CHLO-
RIDE,
OIS-
SOLVEO
(MGIL
AS CL)

1.0
4.2
2.0
5.0
6.5

$\begin{array}{cc}\text { FLUO- } & \text { SILICA, } \\ \text { RIDE, } & \text { OIS- } \\ \text { DIS- } & \text { SOLVEO } \\ \text { SCLVED } & \text { (MG/L } \\ \text { (MGIL } & \text { AS } \\ \text { AS F) } & \text { SIO2) } \\ -- & 8.0 \\ .3 & 4.0 \\ -- & 13 \\ -. & -.0 \\ .1 & 8.0\end{array}$

SOLIOS.

RESI CUE

DEG. C

DIS-

SOLVED

(MG/L)

CALCIUM

CALCIUM
CIS-

SOG

MAGNE-

GNE-

SODIUM,

DIS- DIS-

SOLVED SOLVEO

(MG/L SMG/L

AS MG)

AS NA)

21
6.0

8.5

6.9
4.4
0.8
.--

13

NITRO-

GEN,

MTRATE ARSENIC BARIUM, CADMIUM COPPER,

SOLVED

AS N)

DIS-

DIS-

(UGIL (UG/L

AS AS)

AS BA)

DIS-

SOLVED SOLVED

AS CD) AS CUD

82-03-18 270

6

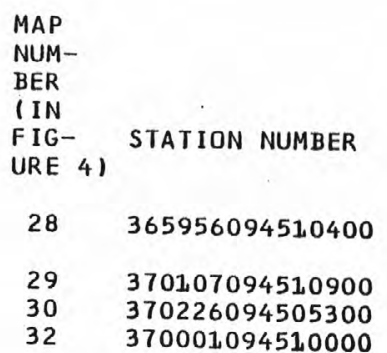

DATE
OF
SAMPLE

$81-08-13$
$82-03-18$
$81-08-13$
$81-06-17$
$32-03-18$

IRON
OIS
SOLVEO
QUG
AS FE

I R.ON,

LEAD,

NESE,

DIS-
SOLVED

NIUM,

DIS-

210

.00

--
0
--

0
200
0
100
100

40
10
0
0
57

AS (U)

(UGIL

(UG/L

(UGIL

DIS-

$F E)$ AS PB)

SE)

AS $Z N$ )

20
150
170
220
0

0
30
0
0
10

40
160
1100
110
140

--
0
--
2

5800

1300

220
70
5800 
Table 24.--Historical chemical water-quality data for wells in shallow and deep aquifers in Kansas [Analyses were performed on unfiltered samples]

\begin{tabular}{|c|c|c|c|c|c|c|c|c|c|c|c|c|c|c|}
\hline $\begin{array}{l}\text { Map } \\
\text { number } \\
\text { (shown } \\
\text { in fig. } \\
\text { 3) }\end{array}$ & $\begin{array}{l}\text { Location } \\
\text { (township- } \\
\text { range- } \\
\text { section) }\end{array}$ & $\begin{array}{l}\text { Principal } \\
\text { aquifer }\end{array}$ & $\begin{array}{c}\text { Depth } \\
\text { of } \\
\text { well } \\
\text { (feet) }\end{array}$ & $\begin{array}{l}\text { Date of } \\
\text { collection } \\
\text { (month- } \\
\text { day-year) }\end{array}$ & $\begin{array}{l}\text { Specific } \\
\text { conductance } \\
\text { (micromhos } \\
\text { per centi- } \\
\text { meter at } \\
25{ }^{\circ} \mathrm{C}\end{array}$ & $\begin{array}{l}\text { Dissolved } \\
\text { solids } \\
\text { milli- } \\
\text { grams } \\
\text { per } \\
\text { liter) } \\
\end{array}$ & $\begin{array}{l}\text { Calcium } \\
\text { (milli- } \\
\text { grams } \\
\text { per } \\
\text { liter) }\end{array}$ & $\begin{array}{l}\text { Magnesium } \\
\text { (milli- } \\
\text { grams } \\
\text { per } \\
\text { liter) }\end{array}$ & $\begin{array}{l}\text { Sodium } \\
\text { (milli- } \\
\text { grams } \\
\text { per } \\
\text { liter) }\end{array}$ & $\begin{array}{l}\text { Potassium } \\
\text { (milli- } \\
\text { grams } \\
\text { per } \\
\text { liter) }\end{array}$ & $\begin{array}{l}\text { Chloride } \\
\text { (milli- } \\
\text { grams } \\
\text { per } \\
\text { liter) }\end{array}$ & $\begin{array}{c}\text { Sulfate } \\
\text { (milli- } \\
\text { grams } \\
\text { per } \\
\text { liter). }\end{array}$ & $\begin{array}{c}\text { Bicarbonate } 1 / \\
\text { (milli- } \\
\text { grams } \\
\text { per } \\
\text { liter) }\end{array}$ & $\begin{array}{c}\text { Silica } \\
\text { (milli- } \\
\text { grams } \\
\text { per } \\
\text { liter) }\end{array}$ \\
\hline $\begin{array}{l}122 \\
123 \\
124 \\
125 \\
126\end{array}$ & $\begin{array}{l}32-22 E-1 D D A \\
32-23 E-24 A D \\
32-24 E-27 D D D \\
32-24 E-30 A A A \\
32-25 E-36 A D D\end{array}$ & $\begin{array}{l}\text { shallow } \\
\text { do. } \\
\text { do. } \\
\text { do. } \\
\text { do. }\end{array}$ & $\begin{array}{l}400 \\
455 \\
400 \\
390 \\
230\end{array}$ & $\begin{array}{r}8-27-64 \\
9-09-64 \\
9-08-64 \\
9-09-64 \\
11-08-63\end{array}$ & $\begin{array}{r}2,130 \\
1,580 \\
2,000 \\
3,080 \\
500\end{array}$ & $\begin{array}{r}1,220 \\
931 \\
1,220 \\
1,810 \\
340\end{array}$ & $\begin{array}{l}32 \\
34 \\
11 \\
34 \\
93\end{array}$ & $\begin{array}{c}15 \\
18 \\
3.5 \\
13 \\
8.3\end{array}$ & $\begin{array}{l}442 \\
303 \\
493 \\
680 \\
6.7\end{array}$ & $\begin{array}{c}8.6 \\
8.6 \\
10 \\
13 \\
1.2\end{array}$ & $\begin{array}{c}231 \\
174 \\
88 \\
385 \\
5.0\end{array}$ & $\begin{array}{l}9.8 \\
84 \\
19 \\
48 \\
140\end{array}$ & $\begin{array}{r}939 \\
610 \\
1,200 \\
1,270 \\
154\end{array}$ & $\begin{array}{c}11 \\
7.2 \\
6.0 \\
7.2 \\
9.0\end{array}$ \\
\hline $\begin{array}{l}127 \\
128 \\
221 \\
223\end{array}$ & $\begin{array}{l}34-25 E-04 A B D \\
34-24 E-31 C D \\
35-23 E-13 B A C \\
32-25 E-31 A A A\end{array}$ & $\begin{array}{l}\text { do. } \\
\text { do. } \\
\text { deep } \\
\text { do. }\end{array}$ & $\begin{array}{r}244 \\
444 \\
1,206 \\
564\end{array}$ & $\begin{array}{l}1-19-42 \\
9-04-42 \\
9-27-67 \\
2-26-64\end{array}$ & $\begin{array}{l}-- \\
720 \\
--\end{array}$ & $\begin{array}{r}1,160 \\
666 \\
492 \\
253\end{array}$ & $\begin{array}{r}226 \\
20 \\
69 \\
54\end{array}$ & $\begin{array}{l}40 \\
8.7 \\
28 \\
26\end{array}$ & $\begin{array}{r}27 \\
218 \\
39 \\
19\end{array}$ & $\begin{array}{r}\sqrt[2]{--} \\
2 \sqrt{-} \\
4.5 \\
5.8\end{array}$ & $\begin{array}{l}14 \\
59 \\
83 \\
7.5\end{array}$ & $\begin{array}{r}426 \\
184 \\
120 \\
54\end{array}$ & $\begin{array}{l}395 \\
342 \\
168 \\
273\end{array}$ & $\begin{array}{l}-- \\
-7.5 \\
6.0\end{array}$ \\
\hline
\end{tabular}

1 Alkalinity values may be derived by multiplying 0.8202 by the bicarbonate value.

2 Concentrations reported for sodium include potassium for analyses collected during the 1940's. 
Table 25.--Chemical constituent or physical property analyzed, reporting units, and detection Timits

Chemical constituent or physical property

Reporting units

Detection

limit

Specific conductance

$\mathrm{pH}$

Temperature

Calcium, dissolved

Mangesium, dissolved

Sodium, dissolved

Potassium, dissolved

Alkalinity (as $\mathrm{CaCO}_{3}$ )

Sulfate, dissolved

Chloride, dissolved

Fluoride, dissolved

Silica, dissolved

Solids, sum of constituents

Nitrogen, nitrate dissolved

as nitrogen

Phosphorous

Arsenic, dissolved

Barium, dissolved

Cadmium, dissolved

Copper, dissolved

Iron, dissolved

Manganese, dissolved

Lead, dissolved

Selenium, dissolved

Zinc, dissolved

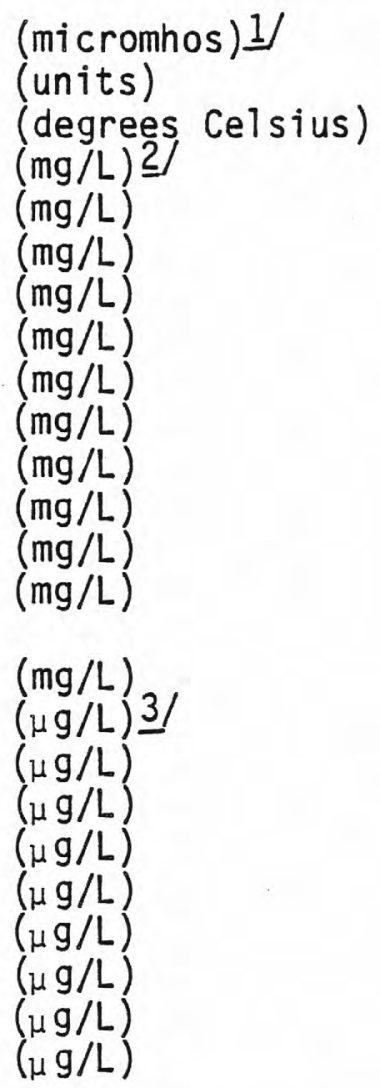

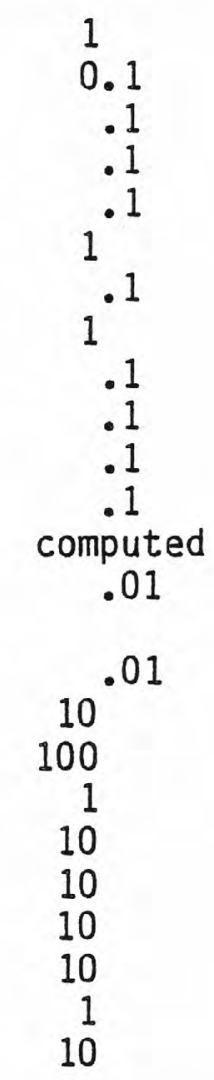

1 Micromhos per centimeter at $25^{\circ}$ Celsius.

2 Milligrams per liter.

3 Micrograms per liter. 
Table 26.--Streamflow and mass-balance calculations for gains and losses in loads of dissolved manganese, cadmium, and zinc for seepage-salinity survey conducted on Short Creek, August 12, 1981

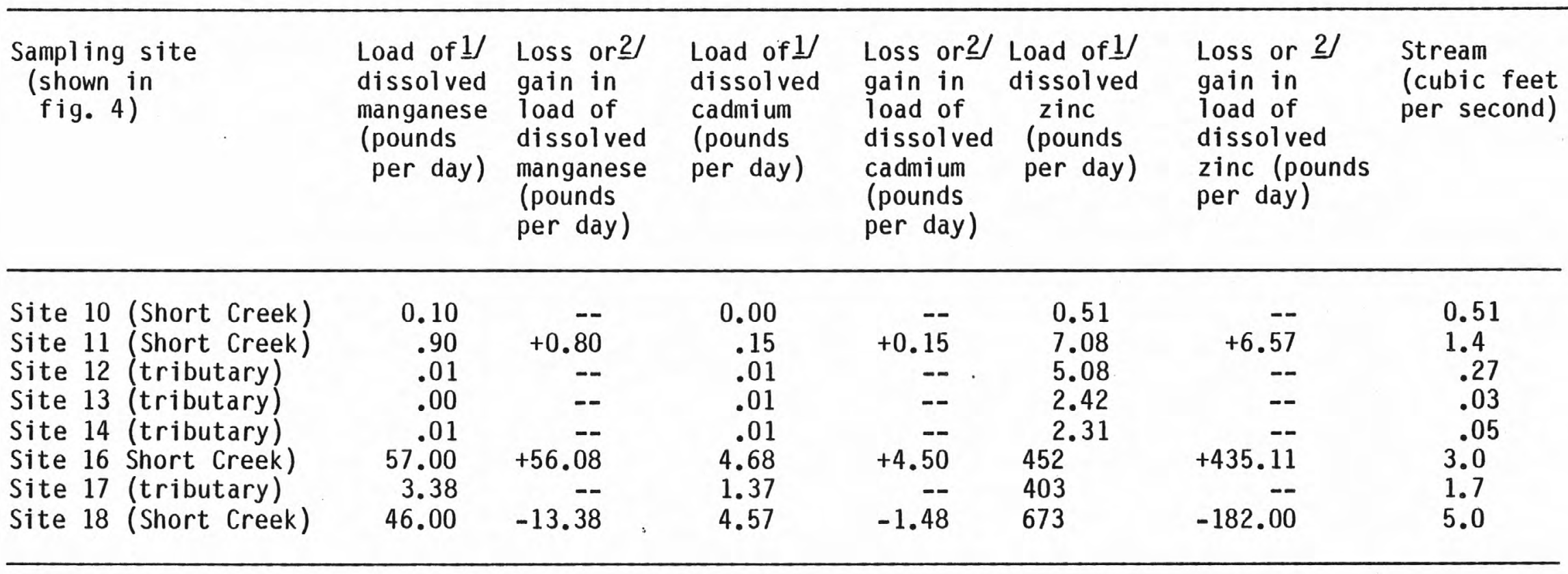

1 Loads were computed in pounds per day for each station using the following formula:

Load (pounds per day) $=$ streamflow (cubic feet per second) $x$ concentration (grams per

1iter) $\times 28.3$ (1iters per cubic feet) $\times 60$ (seconds per minute) $\times 60$ (minutes per

hour) $\times 24$ (hours per day)/ 454 (grams per pound).

2 Gains or losses in loads were computed from the following equation:

$$
\left.\Delta L=L_{0}-\left[L_{u}+\Sigma L_{T}\right]_{j-j}\right] \text {, }
$$

where $\Delta \mathrm{L} \quad=$ Gain or loss in load in Short Creek from upstream sampling site;

$\mathrm{L}_{\mathrm{O}} \quad=$ Load at downstream sampling site;

$\mathrm{L}_{\mathrm{u}} \quad=$ Load at upstream sampling site; and

$\sum L_{T}=\begin{gathered}\text { Cumulative load of all tributaries between upstream and downstream sampling sites } \\ \text { on Short Creek. }\end{gathered}$ 
